DEPARTMENT OF THE INTERIOR

UNITED STATES GEOLOGICAL SURVEY

GEORGE OTIS SMITH, DIRECTOR

Water-S.UPPLy PAPer 255

\title{
UNDERGROUND WATERS FOR FARM USE
}

\author{
BY \\ MYRON L. FULLER
}

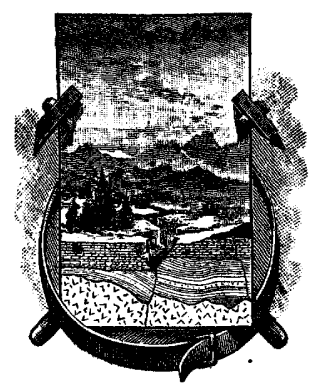

WASHINGTON

GOVERNMENT PRIN'TING OFFICE

1910 



\section{CONTENTS.}

Page.

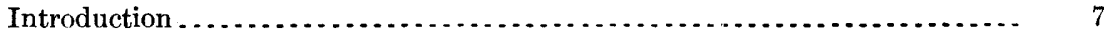

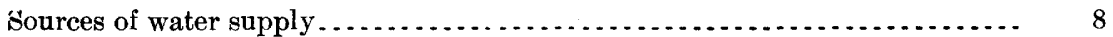

Water-bearing formations....................................... 8

Classes of rocks............................................. 8

Definitions of rocks......................................... 9

Unconsolidated sedimentary deposits .................... 9

Consolidated sedimentary rocks . . . . . . . . . . . . 9

Igneous rocks ........................................ 10

Metamorphic and crystalline rocks ...................... 10

Fossils............................................. 10

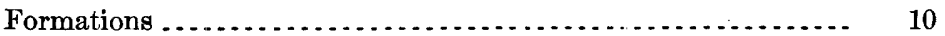

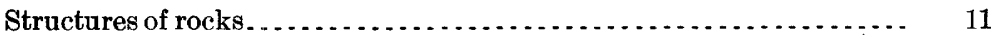

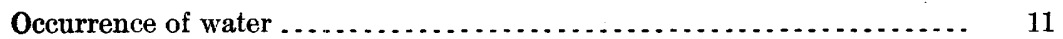

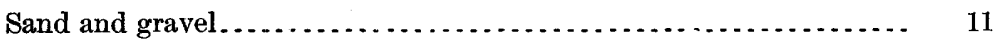

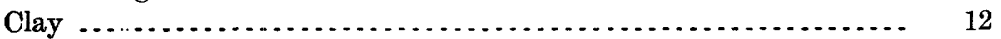

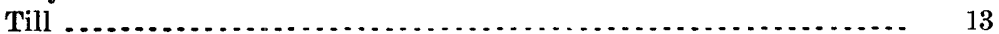

Sandstone, conglomerate, and quartzite..................... 13

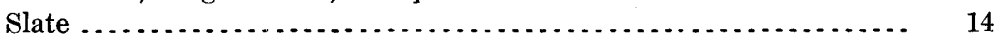

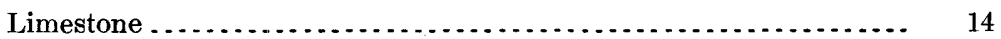

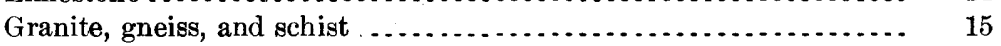

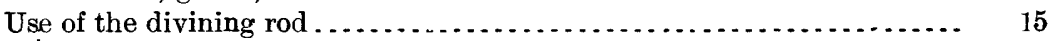

Relative safety of different materials. . . . . . . . . . .

Sands and gravels ...................................... 16

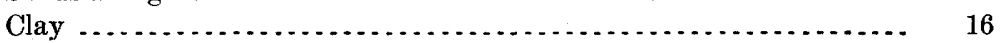

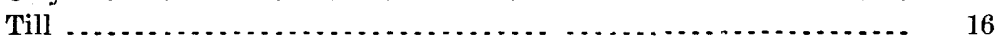

Sandstone, conglomerate, and quartzite . . . . . $\ldots \ldots \ldots \ldots \ldots \ldots \ldots . .17$

Shale and slate............................................ 17

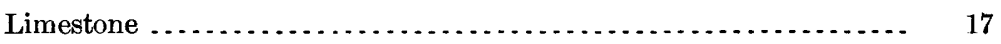

Granite, gneiss, and schist ................................ 18

Common sources of water . . . . . . .

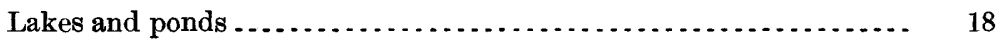

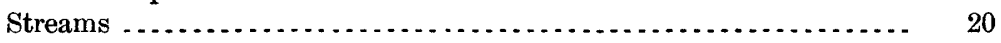

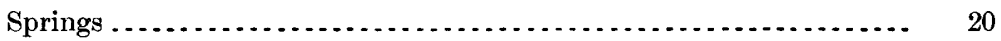

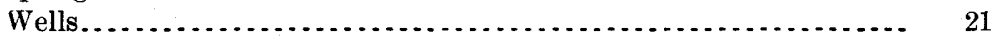

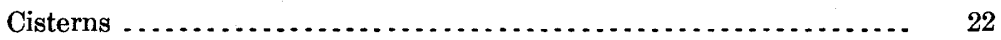

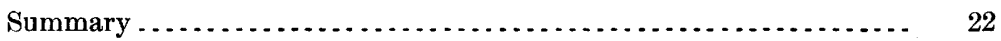

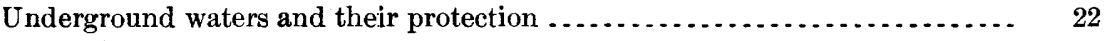

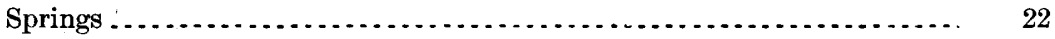

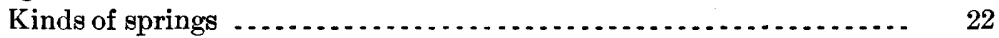

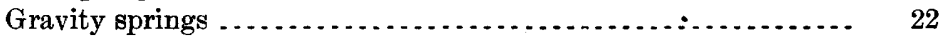

Artesian springs. . . . . . . . . . .

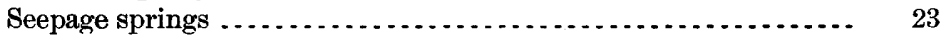

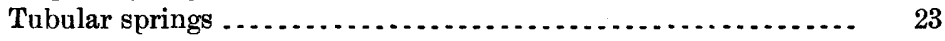

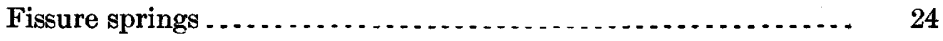


Underground waters and their protection-Continued.

Springs-Continued.

Protection of springs............................................... 25

Protection from stock ..................................... 25

Protection from surface drainage ........................ $\quad 25$

Protection from wind blown and other refuse.............. 25

Protection from subsurface drainage..................... 26

Protection of sink holes................................. 26

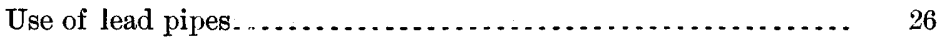

Tests for pollution ...................................... 27

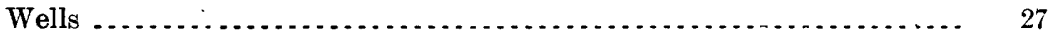

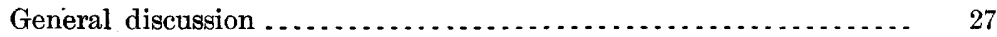

Types of wells........................................ 28

Types of curbs and casings............................ $\quad 30$

Factors governing selection of type of well.................. 32

Yield of wells of various types....................... 32

Character of the material.......................... $\quad 32$

Facility of entrance of water....................... 33

Storage capacity of wells........................... 33

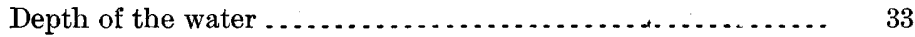

Relative cost of different types of wells ................ 34

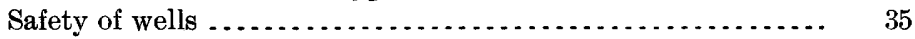

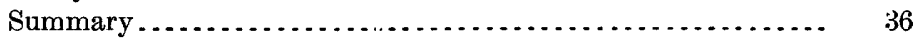

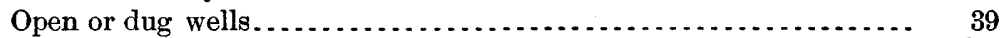

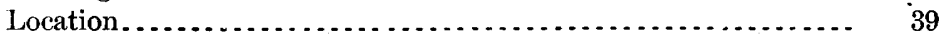

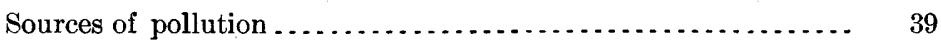

Movement of ground water ............................ 41

"Safety distance" ......................................... 42

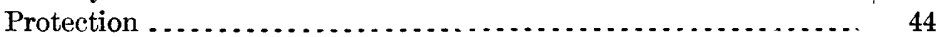

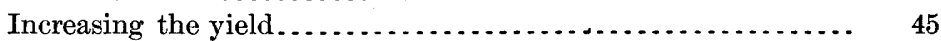

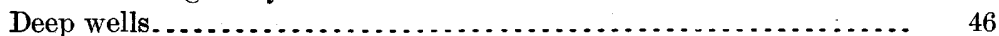

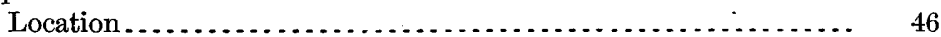

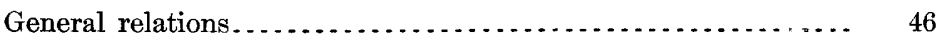

Relation of supply to depth....................... 46

Relation of head to depth......................... 47

Relation of quality to depth....................... 48

Summary of conclusions as to depth.................. 49

Protection ............................................. 49

Nonflowing wells................................... 49

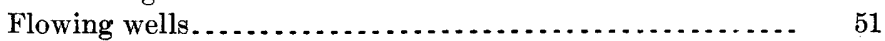

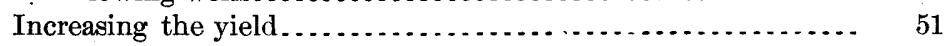

Methods of increasing original yield.................. 51

Methods of restoring lost supplies.................. 52

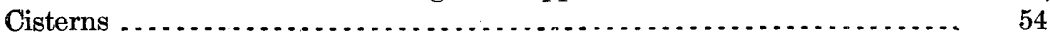

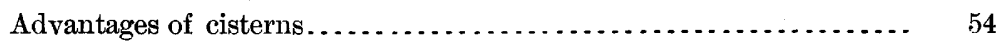

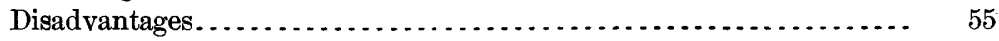

Conditions under which cisterns are desirable................ 55

Size of cistern .......................................... 55

Location.............................................. 57

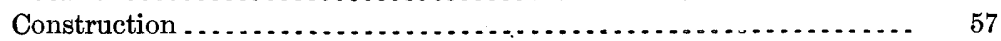

Combination wells and cisterns.................................. 57 . 


\section{ILLUSTRATIONS.}

Plate I. A, View of sedimentary rock, under microscope, showing pore spaces (dark); $B$, Water-bearing formations: Bedded sedimentary

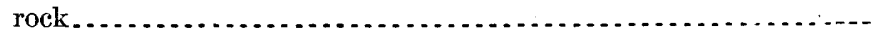

II. Water-bearing formations: $A$, Metamorphic rock (gneiss); $B$, Ig-

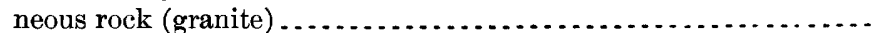

III. Water-bearing formations: $A$, Sandstone; $B$, Conglomerate ........

IV. $A$, Rock containing fossil shells (shell marl); $B$, Concretions in sandstone..............................................

V. Rock structures: $A$, Anticline; $B$, Syncline ....................

VI. $A$, Pollution of ground water: Sewage discharging into sink hole; $B$, Occurrence of ground water: Limestone channel..............

VII. Pollution of surface water; $A$, Outhouses along stream; $B$, Stock in

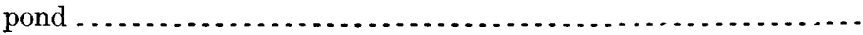

VIII. Pollution of springs: $A$, Spring receiving wash from fertilized land; $B$, Spring receiving pollution from stock and surface wash .......

IX. $A$, Protection of springs: Properly protected spring; $B$, Pollution of springs: Spring open to falling leaves, etc ....................

$\mathrm{X}$. Pollution of springs: $A$, Spring in center of city street; $B$, Dairy spring from polluted underground stream .....................

XI. $A$, Open dug well; $B$, Bored well.......................... 28

XII. Methods of sinking wells: $A$, The jet outfit; $B$, The driven well.... 28

XIII. Methods of sinking wells: $A$, Standard portable rig; $B$, Rotary apparatus............................................ 28

XIV. Methods of raising water: $A$, Pitcher pump; $B$, Deep-well pump... 28

XV. Methods of raising water: $A$, Windmill; $B$, Natural flow .......... 28

XVI. Protection of wells: $A$, Drilled well with opening between outer casing and pump tube unprotected; $B$, Drilled well with opening around casing protected by cement........................

XVIr. $A$, Well points: $B$, Pulling pipe with jack .....................

Figure 1. Diagram showing common location of farm wells...............

2. Diagram showing relation between depth and permanency of wells: $A$, Well sunk to ordinary water level, but failing in times of drought; $B$, Well sunk to level of water in dry years and never failing............................................

3. Diagram showing action of clays or shales in confining waters in sands and sandstones................................... 12

4. Relative size and storage capacity of dug and drilled wells .........

5. Diagram illustrating arrangement of grains in sands and sandstones with intervening pores open and capable of holding water.

6. Diagram illustrating arrangement of grains in sands and sandstones with intervening pores filled with mineral matter preventing the absorption of water...........................

7. Difference in conditions in adjacent wells in limestone............ 


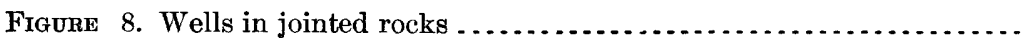

9. Diagram showing possibility of pollution of wells and springs by material conducted from cesspool by tubular water passages in till

10. Limestone passage connected with sinks.

11. Spring fed from unconfined waters in porous sands.............

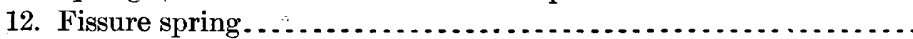

13. Diagram showing manner in which springs may be polluted by subsurface drainage................................... 26

14. Common form of well auger........................... 28

15. Outfit for sinking wells by jet process. . . . . . . . . . . . . . . . . . 29

16. Outfit for sinking wells by rotary process................... 29

17. Section showing relation of water table to surface irregularities... 40

18. Map showing position of water table by contours............. 41

19. Artesian system showing progressively higher outcrops of the deeper beds.

20. Artesian system showing progressively lower outcrops of deeper beds.

21. Diagrams showing danger of pollution where well casing is carried only to rock

22. Diagram showing "loosening" effect of shooting wells......... 51

23. Diagram showing formation of sand packing through pumping... 52

24. Diagram showing advantages of packing with sand and gravel... 52

25. Section of well showing leakage into superficial deposits........ 53

26. Section of well showing leakage from one deep bed into another.. $\quad 53$

27. Combination well and cistern........................ 58 


\title{
UNDERGROUND WATERS FOR FARM USE.
}

\author{
By Myron L. Fuller.
}

\section{INTRODUCTION.}

The agricultural lands of the United States, constituting, as they do, almost the whole of the eastern half of the country as well as a very large proportion of the habitable areas in the West, deserve to have especial attention paid to their needs. Of these needs few are greater than that of purer water supplies. Farms, which are generally remote from towns, cities, or other areas of congested population, seem to be almost ideally situated for obtaining pure and wholesome water. In.reality, however, polluted water is exceedingly common on them (fig. 1) and typhoid-fever rates are usually

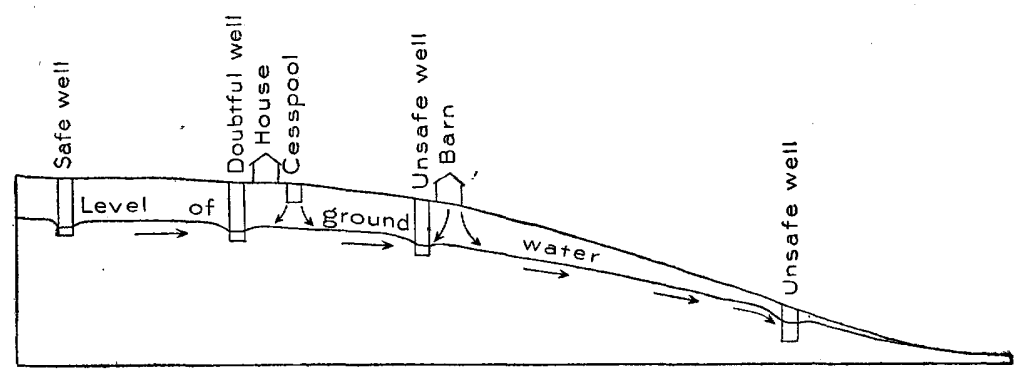

FIGURE 1.-Diagram showing ordinary location of farm well.

greater in country districts than in cities. Typhoid fever is now almost universally believed to be transmitted solely through drink or food taken into the stomach, and is especially liable to be communicated by polluted waters obtained from shallow wells near spots where the discharges of typhoid patients have been thrown upon the ground and subsequently carried down through the soil and into the wells, and it is doubtless principally this fact that makes the disease so common in farming regions.

Many of the failures to protect adequately the water supplies used for drinking arise from a lack of knowledge of the manner in which waters circulate through the ground and of the ways in which they may become polluted. Information on these subjects must needs 
be of value, and it is with the object of supplying this information, in so far as it may be possible to furnish it in a brief paper, that the present report has been prepared.

\section{SOURCES OF WATER SUPPLY.}

\section{WATER-BEARING FORMATIONS.}

All known rocks contain more or less water, and though many of them will not yield it in useful quantities to wells all must be considered in a discussion of water-bearing formations. Many rocks are familiar to everyone, at least by name; others are less widely known and may be restricted to very small areas. The classes of rocks commonly recognized and the definitions of the simpler varieties are given below for the benefit of those not familiar with the terms in use.

\section{ClASSES OF ROCKS.}

In a simple classification rocks may be grouped into three divisions: (1) Sedimentary, (2) igneous, and (3) metamorphic.

Sedimentary rocks (Pl. I) are formed either of fragments worn from older rocks by the action of rain, wind, frost, etc., and carried by water, wind, or glaciers until deposited as beds of clay, sand, gravel, marl, loess, etc.; or of the remains of corals or of shellfish, such as oysters and clams. When first deposited the materials are loose and unconsolidated, but gradually they become hardened and cemented together, especially when covered by later beds, and eventually form solid rocks. These fragments or grains are commonly rounded, and their form may therefore help to distinguish them from igneous rocks, which may have corners or angles or may include angular crystals.

Igneous rocks (Pl. II, $B$ ) may have come from the earth's interior in a molten state and have been forced into or through the rocks above them or may have overflowed as lava beds at the surface. They are generally made up of or at least include angular crystals, which may be recognized by their glistening faces, a feature that is not usually possessed by sedimentary rocks. Many of them are banded and most of them are irregular in mass and occurrence; locally they may contain vividly colored patches and bands.

Sedimentary and igneous rocks in many places have been subjected to heat and pressure after their deposition. This action may have further hardened them or have so greatly changed them that their original character can scarcely be determined. Rocks thus changed are known as metamorphic rocks (Pl. II, $A$ ). Mica schist and marble are typical examples. As a rule they exhibit a bedded or banded structure.

Rocks of all of these types occur the world over, and those of one locality may be indistinguishable from those of another. Notwith- 


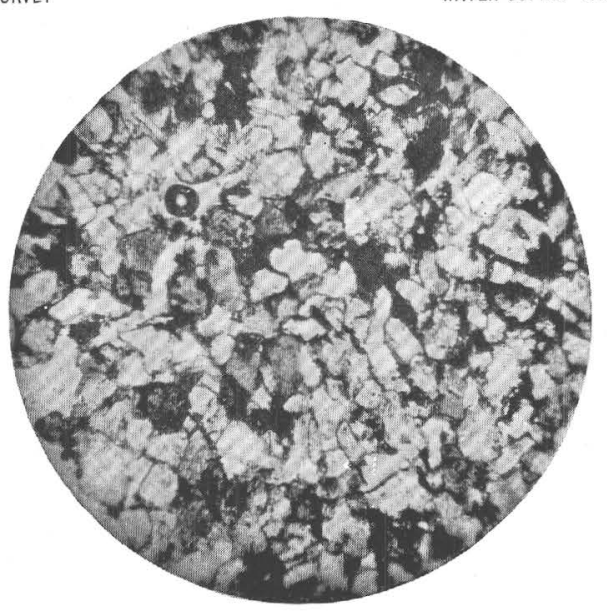

A. VIEW OF SEDIMENTARY ROCK UNDER MICROSCOPE, SHOWING PORE SPACES (DARK).

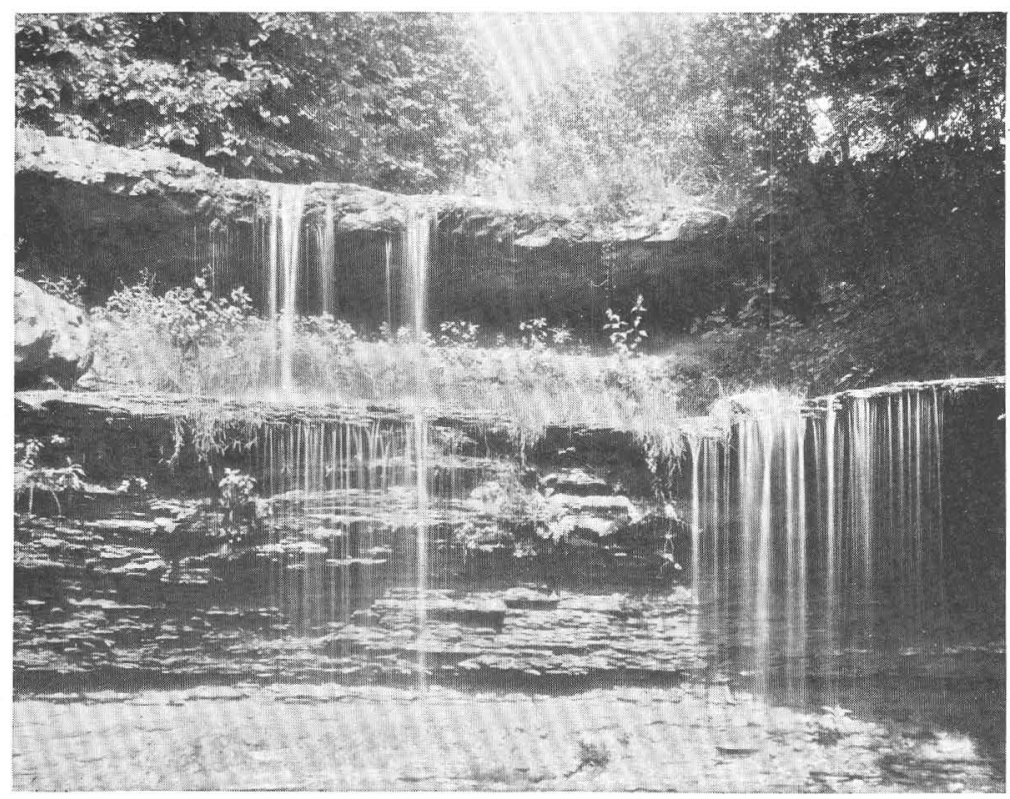

B. WATER-BEARING FORMATIONS: BEDDED SEDIMENTARY ROCKS. 


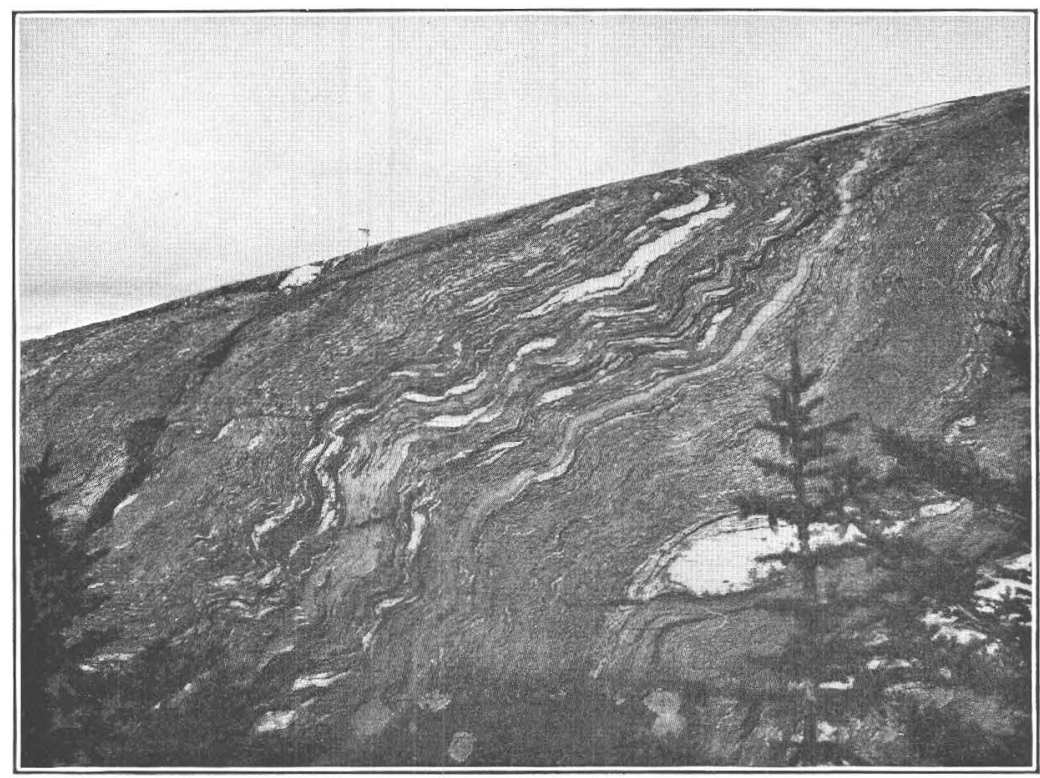

A. METAMORPHIC ROCK (GNEISS).

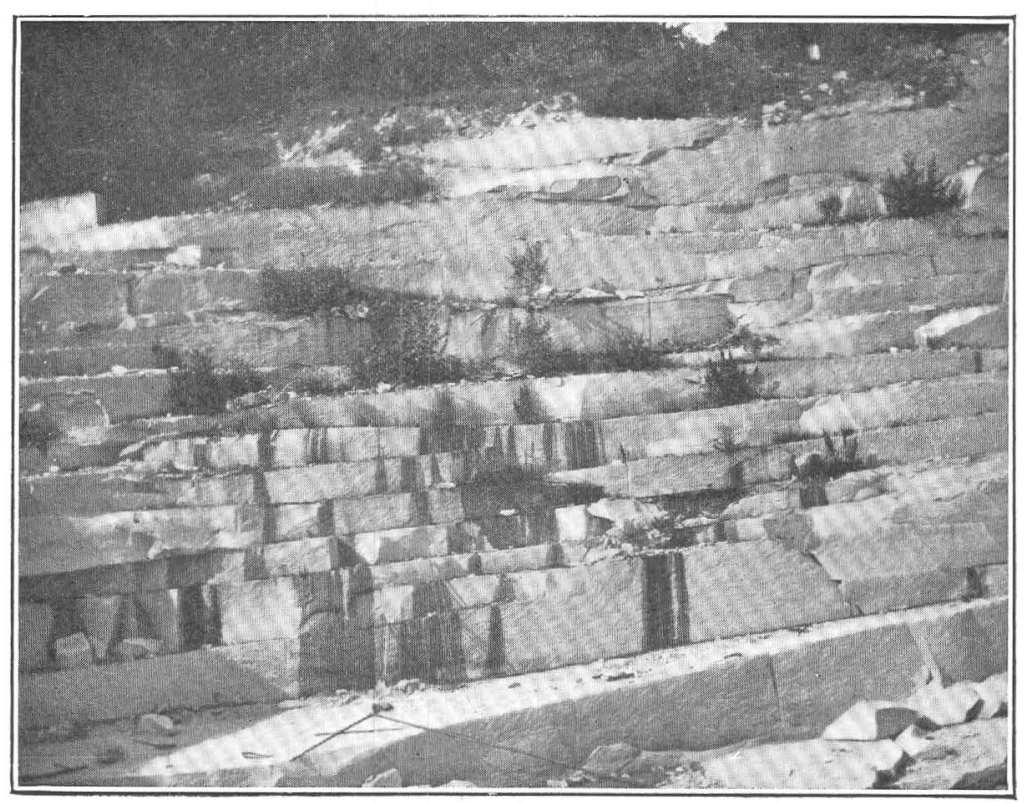

B. IGNEOUS ROCK (GRANITE).

WATER-BEARING FORMATIONS. 


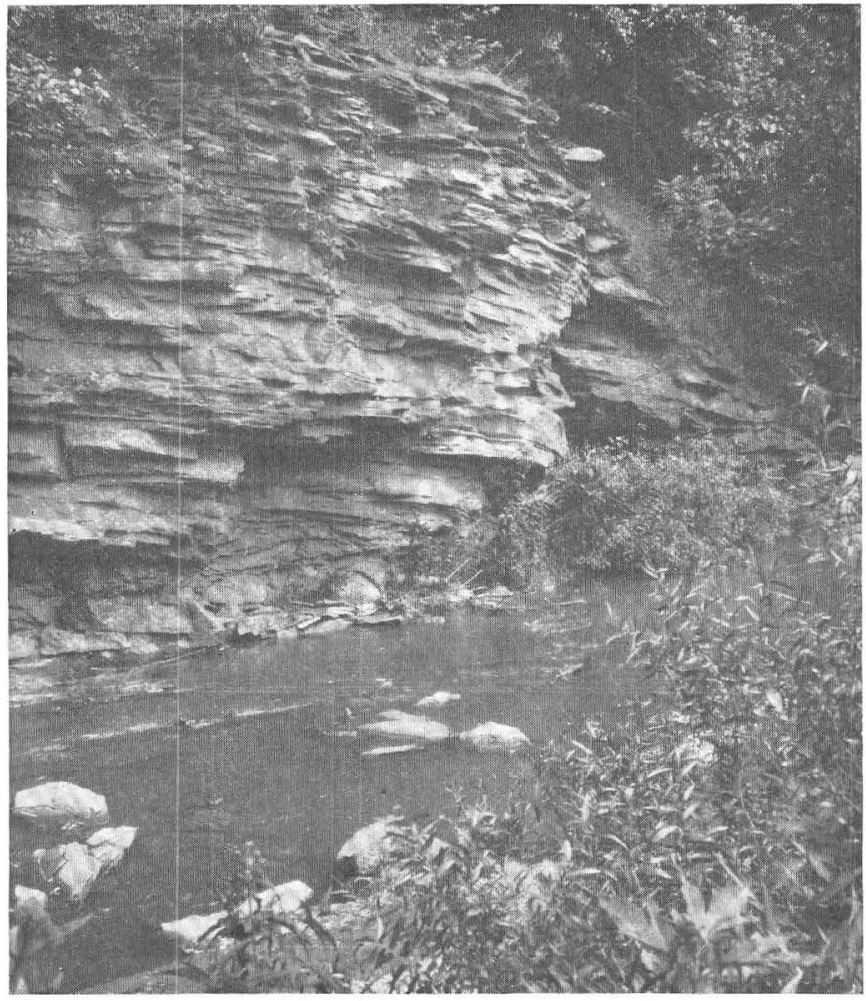

A. SANDSTONE.

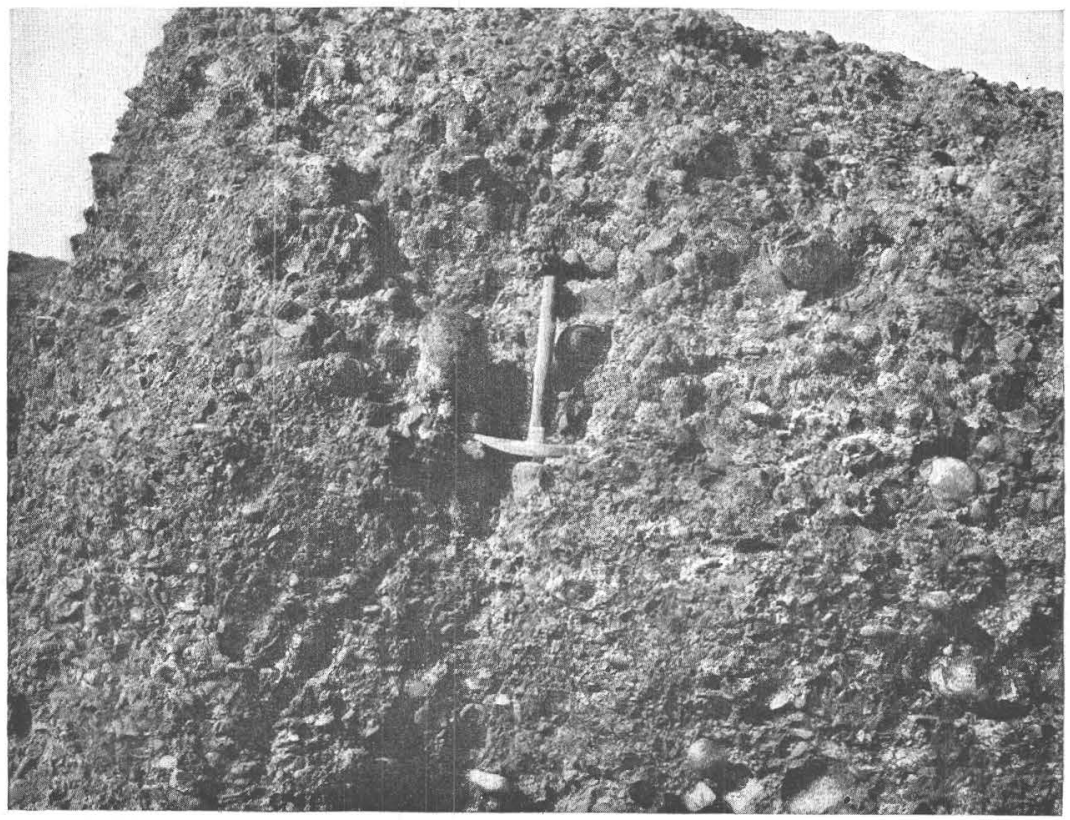

B. CONGLOMERATE 


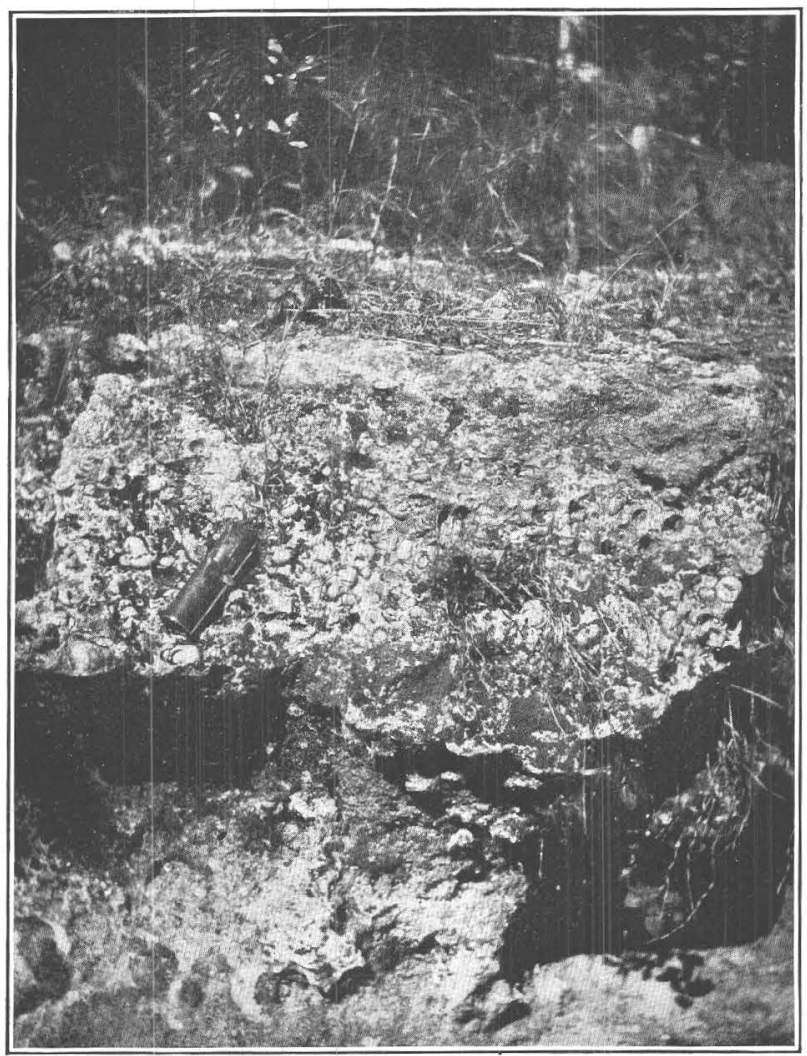

A. ROCK CONTAINING FOSSIL SHELLS (SHELL MARL).

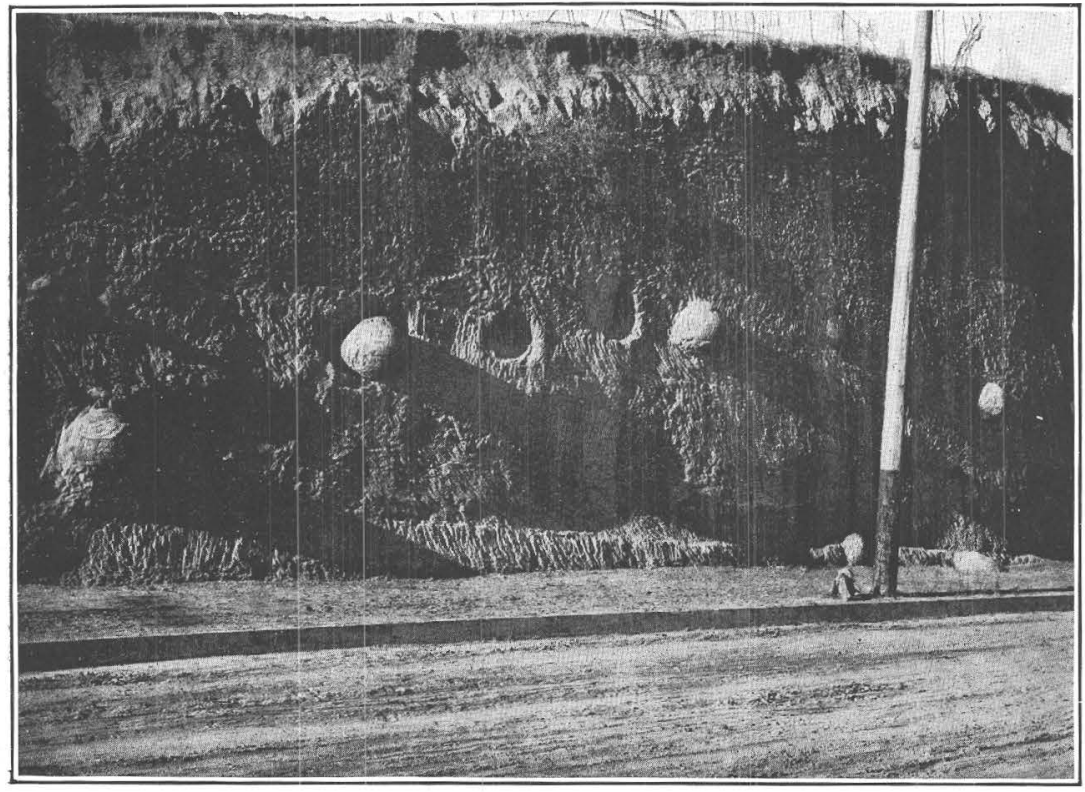

B. CONCRETIONS IN SANDSTONE. 
standing these similarities, they may have been formed under very different conditions and at periods thousands or even millions of years apart. Resemblances between rocks do not, therefore, mean that they were formed at the same time or will yield the same products, such as coal or oil or water.

\section{DEFINITIONS OF ROCKS.}

Simple definitions of the more common rocks are given below. Complete descriptions and definitions of rarer varieties may be found in any text-book on geology.

\section{UNCONSOLIDATED SEDIMENTARY DEPOSITS.}

Gravel, sand, and clay are made up respectively of pebbles, sand grains, and fine silts worn from older rocks and redeposited in their present form.

Alluvium is a general term for gravels, sands, and clays, or mixtures of these that have been deposited by streams.

Chalk is a soft white earthy form of limestone.

Marl is a clay with much intermingled calcareous material.

Till is a heterogeneous mixture of clay, sand, pebbles, and bowlders deposited by glaciers.

Hardpan is a general term which may be applied to any bed which is considerably harder than those with which it is associated. It is often applied to till, to tough clays, or to partly cemented sand or clay beds.

CONSOLIDATED SEDIMENTARY ROCKS.

Conglomerate (Pl. III, $B$ ) is a consolidated gravel.

Sandstone (Pl. III, $A$ ) is a consolidated sand. It is said to be massive if there are few bedding planes, and shaly if it splits into plates.

Quartzite is a sandstone in which the spaces between the grains have been filled with a hard cement (silica), forming an excessively hard rock.

Shale is consolidated clay; a soft, fine-grained rock which tends to split into thin plates. It is sometimes improperly called soapstone.

Limestone is composed mainly of carbonate of lime, but often contains sand and other impurities, and may be very hard. Not infrequently it contains many shells or is made up entirely of them. It can be most readily recognized by the bubbling which takes place when it is touched with hydrochloric (muriatic) acid. In varieties high in magnesia and in magnesium carbonate, or dolomite, hot, strong muriatic acid is necessary to produce this action.

Tuff is any sedimentary rock that is made up entirely or almost entirely of fresh fragments of volcanic rocks. 
Concretions (Pl. IV, B) are hard, lumplike masses within the rock. They should not be confounded with real bowlders, from which, as a rule, they may readily be distinguished, because they consist of nearly the same material as that in which they are embedded.

IGNEOUS ROCKS.

Granite is a wholly crystalline rock, composed of quartz, feldspar, and other light-colored minerals.

Diorite, gabbro, and diabase are crystalline rocks similar to granite, but with less quartz and with dark-colored feldspars.

Volcanic rocks, lavas, etc., are rocks that have been emitted in a molten state from volcanoes.

Trap is a widely distributed, compact, very dárk colored variety of volcanic rock. Technically it is a basalt or diabase, and these terms are in common use.

\section{METAMORPHIC AND CRYSTALLINE ROCKS.}

Slate is like shale, but harder; it splits into thin plates which may or may not coincide with the bedding. The tendency to split is not often recognized in drilling. Roofing slate is a familiar example.

Marble is a crystalline limestone, and gives the same reaction with acid as limestone, marl, and chalk.

True soapstone is a soft, even-grained, greasy-feeling rock composed of the mineral tale, but the term is incorrectly applied to any soft, greasy-feeling rock, such as soft shale.

Schist is a more or less crystalline rock which has a laminated structure, due to the flat crystals of mica or other minerals of which it is composed.

Gneiss is similar to granite in composition, but has a less perfect crystalline structure and a banded structure due to the linear arrangement of its crystals.

FOSSILS.

In many sedimentary rocks remains of animals and plants are found. (See Pl. IV, A.) These generally consist of portions or impressions of shells, skeletons, or leaves, and are known as fossils. A bed may be recognized and determined by such remains, which are therefore of great importance in geologic work. In the oldest rocks only low organisms, such as shellfish, are found, but in later rocks, fishes, reptiles, and mammals progressively appear, while vegetation shows a corresponding change of its predominant types from microscopic forms to the forest trees of to-day.

FORMATIONS.

A rock bed or a succession of beds that are uniform in character throughout a considerable area is termed a formation and is given 
a geographic name derived from some place or feature in the area where it typically occurs, such as Trenton limestone. The correct identification of formations is very important in underground-water studies, as by this means the structure and position of water-bearing beds is worked out.

\section{STRUCTURES OF ROCKS.}

When deposited, sedimentary beds are nearly horizontal, but they may be subsequently thrown into inclined positions, or bent into arches or troughs, or broken and displaced. It is rather unusual, in fact, to find in the interior of the continents any sedimentary beds which have not been tilted, folded, or otherwise disturbed, at least slightly. Some of the terms used to designate the structures that result from these disturbances are as follows:

An anticline (Pl. V, $A$ ) is the arched part of a rock fold.

A syncline ( $\mathrm{Pl} . \mathrm{V}, B)$ is the trough of a rock fold.

A fault is a rock fracture the sides of which have been displaced from their original position with reference to one another.

The dip of a bed is the angle by which it deviates from the horizontal plane.

Strike is the compass direction of the intersection of an inclined bed with a horizontal surface.

A joint is a plane of fracture or crack in a rock the sides of which have not been materially displaced with reference to one another.

Cleavage planes are minor planes traversing a rock, as a rule in one direction, and in many rocks are simply lines along which the rock tends to split rather than. actual fractures. They are commonly due to the action of pressure on compact rocks.

Foliation and schistosity are planes of easy splitting, due to the arrangement of the minerals of the rock with their elongated directions parallel with one another.

\section{OCCURRENCE OF WATER.}

All rocks contain more or less water, which either occupies perceptible cavities in the rock or occurs within the minute pores. The water in the pores is given up readily only by the coarser rocks, such as sandstones, the fine-grained rocks yielding very little of such water when penetrated by the drill. Water found in these rocks usually comes from the joint, fault, or foliation planes. The conditions of the occurrence of water in various rocks differ widely.

\section{SAND AND GRAVEL.}

Sands and gravels are very porous. Thirty per cent of the volume of some sand or gravel deposits are made up of free space between the grains. Im material the whole mass below ground-water level is 
saturated, and when penetrated by wells yields copious supplies. The waters of such deposits are, ás a rule, of good quality, but some are mineralized, having dissolved material from the more soluble fragments and particles that constitute the deposits.

The cheapest and best method of obtaining small supplies of water from sands and fine gravels is by driven wells, which can be sunk

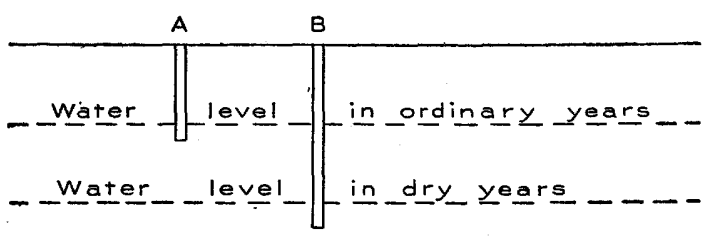

FIGURE 2.-Diagram showing relation between depth and permanence of wells.-A, Well sunk to ordinary water level, but failing at times of drought; $B$, well sunk to level of water in dry years and never failing. quickly and at slight cost. It is difficult, however, to exclude very fine sand or quicksand from pipes, quicksand frequently penetrating the well and clogging the pipe or ruining the pump. Because of the readiness with which sands and gravels yield their water, wells sunk close together in such deposits may affect one another, the well that draws from the sand at the lowest level taking the water from the higher wells. The readiness of movement of the water also causes important fluctuations of the water in the ground, the water level rising and falling rapidly with the beginning and cessation of rain. To obtain permanent supplies, wells should penetrate to a level below that of the ground-water surface in the driest seasons. (See fig. 2.)

\section{CLAY.}

Clay usually contains large quantities of water, but its pore spaces are so fine or small that water soaks into it or out of it so slowly that it is impervious in the sense that little or none of that which it contains can be utilized as a source of supply. Considerable amounts are frequently reported in clays, but they usually come from more or less sandy layers. In some places sand that approaches clay in fineness and that is sometimes mistaken for clay yields considerable amounts of water. Clay is of the greatest importance, however, not as a water-

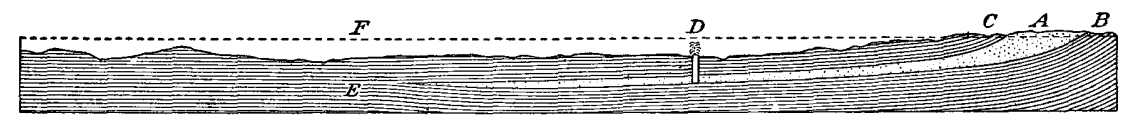

FIGURE 3.-Diagram showing action of clays or shales in confining water in sand or sandstone.

bearer, but as a confining layer which prevents the water from escaping, or as a layer collecting the water from overlying porous beds and bringing it to the surface. (See fig. 3.)

When, because of the absence of other sources, it is necessary to obtain supplies from clay, a well sunk should be of as large diameter as possible and should be continued far enough beneath the point at 
which water is obtained to insure ample storage capacity. (See fig. 4.) Dug wells are usually most satisfactory where the clay is near the surface, but such wells should be carefully covered and guarded from all sources of pollution.

\section{TILL.}

Till is a heterogeneous mixture of clay, sand, gravel, and bowlders, deposited by glaciers. In texture it varies from porous to impervious, according to whether sand or clay predominates. It is, as a rule, not definitely bedded. The water that it contains generally occurs in small more or less tubular channels a few inches in diameter, but here and there is distributed through interstratified sandy beds.

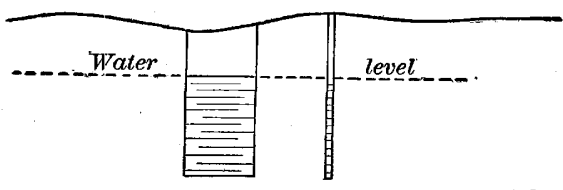

FIGURE 4.-Relative size and storage capacity of dug and drilled wells.

In the aggregate, till yields a large amount of water, being the prevailing source of supply in the rural districts at a great number of points throughout the northern portion of the country. Because of the occurrence of the water in definite channels, however, the success of wells in till varies greatly. In general, wells of large diameter give the best success. Figure 4 represents two wells of the same depth, one dug and one bored. It will be seen that in the dug well not only is a larger amount of material encountered in cross section, but the area of surface from which water can enter is many times greater than in the bored well. The open well is also of larger storage capacity, and can be employed to utilize small supplies-supplies that would be insufficient to furnish enough water to a bored well.

\section{SANDSTONE, CONGLOMERATE, AND QUARTZITE.}

Figure 5.-Arrangement of grains in sands and sandstones with intervening pores open and capable of holding water.
Sandstone is, on the whole, the best water bearer of the solid rocks. Under the most favorable conditions sandstone is saturated throughout its extent below the regular ground-water level, and

wherever it is struck by the drill within these limits (see fig. 5) it yields water freely, as a rule, although some of the finer-grained sandstones yield it less readily. In quality the water in sandstones is, as a rule, better than that in any other material except sand and gravel. Drilled wells are used to recover water from sandstone except where it is very near the surface.

Some conglomerates furnish considerable water, although, as a rule, the absorptive power of conglomerates is not so great as that of sandstones, and they are much less frequently encountered.

Quartzite is a sandstone in which the spaces between the grains have been filled by hard siliceous matter. Because of the filling of 
the pores by this material there is relatively little chance for the water to enter, and the rocks are not commonly an important source of supply. (See fig. 6.)

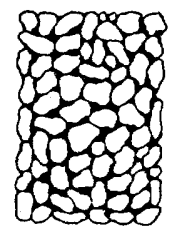

FIGURE 6.-Arrangement of grains in sands and sandstones with intervening pores filled with mineral matter preventing the absorption of water.

SLATE.

Slate, like clay, is a poor water bearer but may yield water from crevices along bedding, joint, and cleavage planes. Its most important use with reference to water supply, is as a confining layer to prevent the escape of water from porous sandstones which may be interbedded with it. The waters in slate are reached by deep wells and are generally uncontaminated but are not uncommonly mineralized.

\section{LIMESTONE.}

Waters occur in limestone mainly in open channels (Pl. VI, $B$ ), caverns, etc., dissolved in the rock by the water itself. The water originally probably followed joint or bedding planes which were gradually enlarged by solution into the caverns that now exist.

The occurrence of caverns and passages within the limestone is very irregular, and their location can seldom be predicted. Most

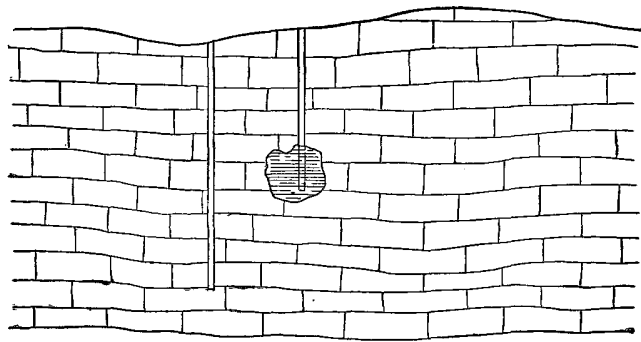

FIGURE 7.-Difference in conditions of adjacent wells in limestone. deep wells which are drilled in limestone regions, however, encounter

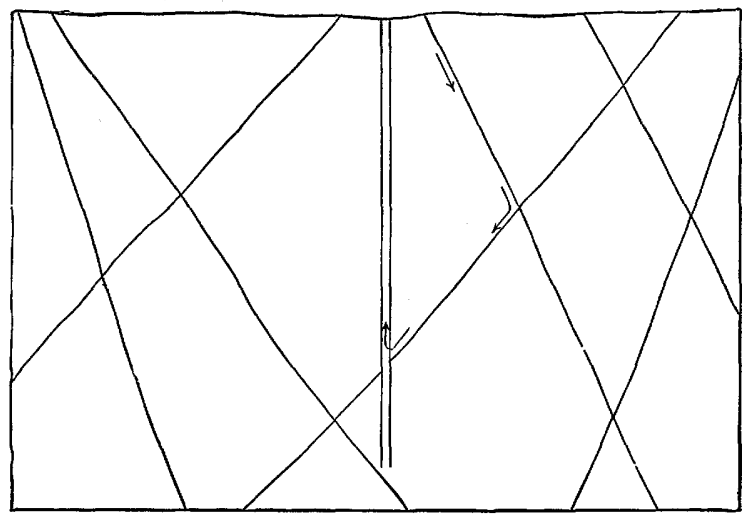

Figure 8.-Wells in jointed rocks. one or more such passages at a relatively slight distance below the surface. Wells in limestone, even where only a few feet apart, may nevertheless obtain very different results, as a difference of a foot or two may mean the missing of a certain channel, as indicated in figure 7. The waters in limestone are generally hard but are not commonly otherwise mineralized. 
GRANITE, GNEISS, AND SCHIST.

Granites and gneisses are very dense and possess very small pore spaces, and most of these rocks hold very little water. In schists, however, considerable water often penetrates along the foliation planes and is held by the rock, but such water is given up very slowly and is not important as a source of supply.

It is along the joints in these rocks that the largest supplies are obtained. (See fig. 8.) These joints are most common near the surface and diminish in number and in definiteness as the depth increases. For this reason the water supplies from such rocks, if obtained at all, are usually found within 200 or 300 feet of the surface. It is generally useless to go deeper than 500 feet for waters in these crystalline rocks, although in some places, as at Atlanta, Ga., water is said to have been obtained at depths as great as 1,600 feet.

\section{USE OF THE DIVINING ROD.}

Numerous mechanical devices have been proposed for detecting the presence of underground water, ranging in complexity from the simple forked branch of witch-hazel, peach, or other wood to more or less elaborate mechanical or electric contrivances. Many of the operators of these devices, especially those who use the home-cut forked branch, are entirely honest in the belief that the working of the rod is influenced by agencies--usually regarded as electric currents following underground streams of water-that are entirely independent of their own bodies, and many uneducated people have implicit faith in their ability to locate underground water in this way. In experiments with a rod of this type the writer found that at certain points it seemed to turn downward independent of his will, but more complete tests showed that this downturning resulted from slight.and, until watched for, unconscious muscular action, the effects of which were communicated through the arms and wrists to the rod. No movement of the rod from causes outside of the body could be detected and it soon became obvious that the view held by other men of science is correct-that the operation of the "divining rod" is generally due to unconscious movements of the body or of the muscles of the hand. The experiments made show that these movements happen most frequently at places where the operator's experience has led him to believe that water may be found.

The uselessness of the divining rod is indicated by the facts that it may be worked at will by the operator, that he fails to detect strong water current in tunnels and other channels that afford no surface indications of water, and that his locations in limestone regions where water flows in well-defined channels are no more successful than those dependent on mere guesses. In fact, its operators are successful 
only in regions in which ground water occurs in a definite sheet in porous material or in more or less clayey deposits, such as pebbly clay or till. In such regions few failures can occur, for wells can get water almost anywhere. Ground water occurs under certain definite conditions, and just as surface streams may be expected wherever there is a valley, so ground water may be found where certain rocks and conditions exist. No appliance, either mechanical or electrical, has yet been devised that will detect water in places where plain common sense will not show its presence just as well. The only advantage of employing a "water witch," as the operator of the divining rod is sometimes called, is that crudely skilled services are thus occasionally obtained, since the men so employed, if endowed with any natural shrewdness, become through their experience in locating wells better observers of the occurrence and movements of ground water than the average person.

\section{RELATIVE SAFETY OF DIFFERENT MATERIALS.}

The safety of the water supplies used for drinking purposes when near any source of pollution, depends principally upon the character of the openings through which the water passes, and this in turn depends on the nature of the materials in which the water occurs or through which it has passed.

Sands and gravels.-In passing downward through sand surface waters are subjected to natural filtration, especially in the finer varieties, and the substances with which they may have originally been polluted are frequently removed, at least in part. In coarser sands and in gravel the water passes downward more rapidly; the conditions are less favorable for filtration, and the water may remain polluted. In general, however, waters from sands and gravels, if taken from a considerable distance below the surface, are safe to use.

Clay.-The waters of clays, because of the fineness of the material, come into contact with relatively large amounts of mineral matter and frequently become mineralized, lime and salt being the most common substances dissolved; as a rule, however, owing to the filtration of the waters through the exceedingly fine material and the slowness with which polluting matter progresses and the slight distance to which it reaches in such material, they are free from contamination.

Till.-The water of till is generally uncontaminated because of the natural filtration due to its slow downward penetration through the clay and sand of which the till is largely composed. In some places, however, springs have formed more or less definite tubular channels through the material, and if such a channel leads from a cesspool or similar source of pollution the water becomes highly charged with matter dangerous to the health. Once contaminated it is likely to 


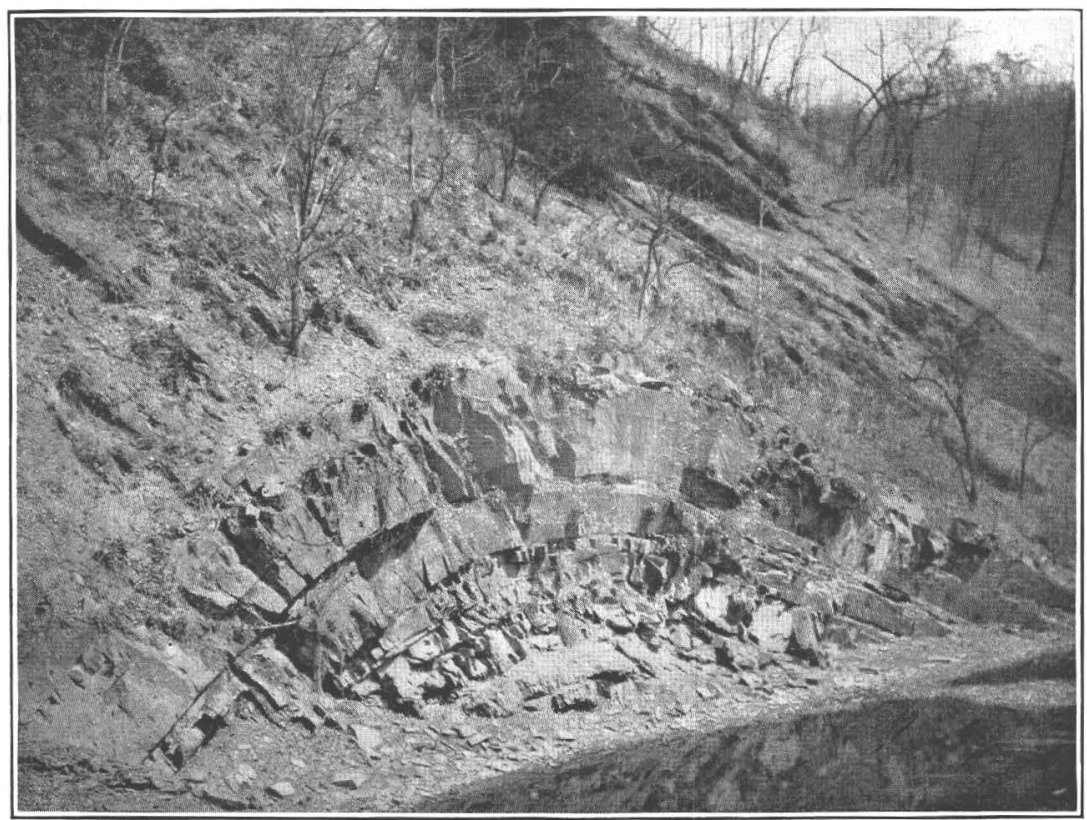

A. ANTICLINE.

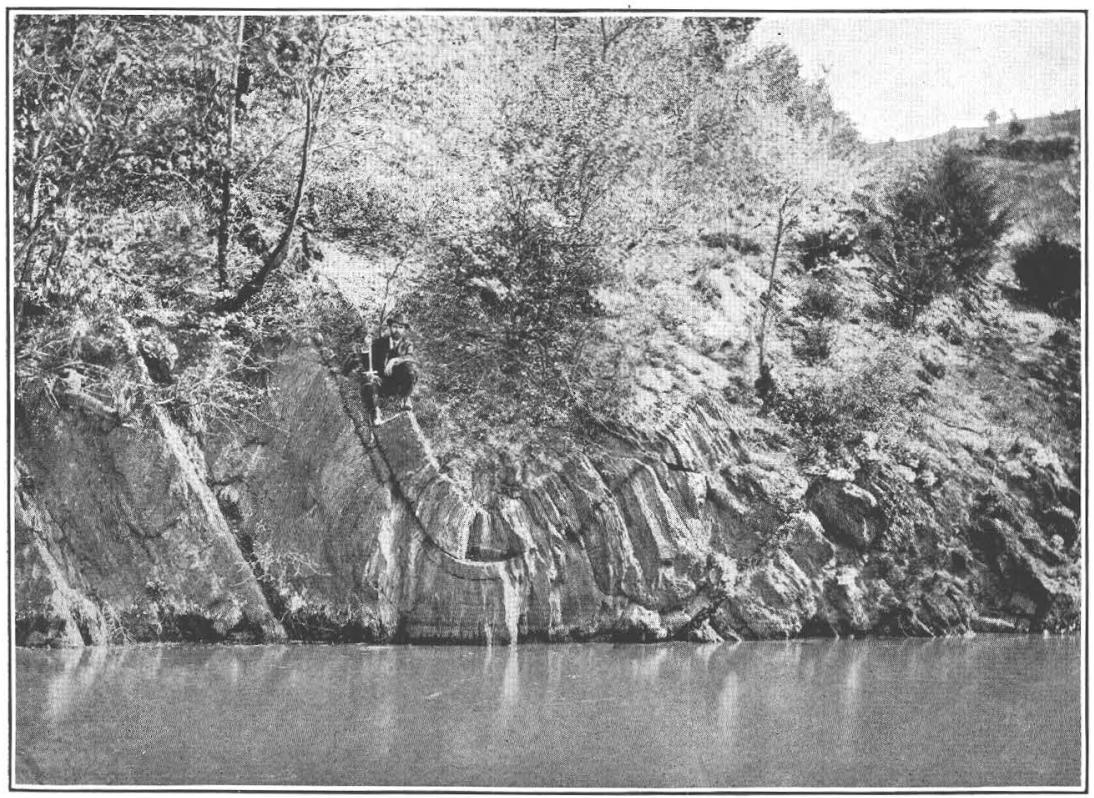

B. SYNCLINE.

ROCK STRUCTURES. 
U. S. GEOLOGICAL SURVEY

WATER-SUPPLY PAPER 255 PLATE VI

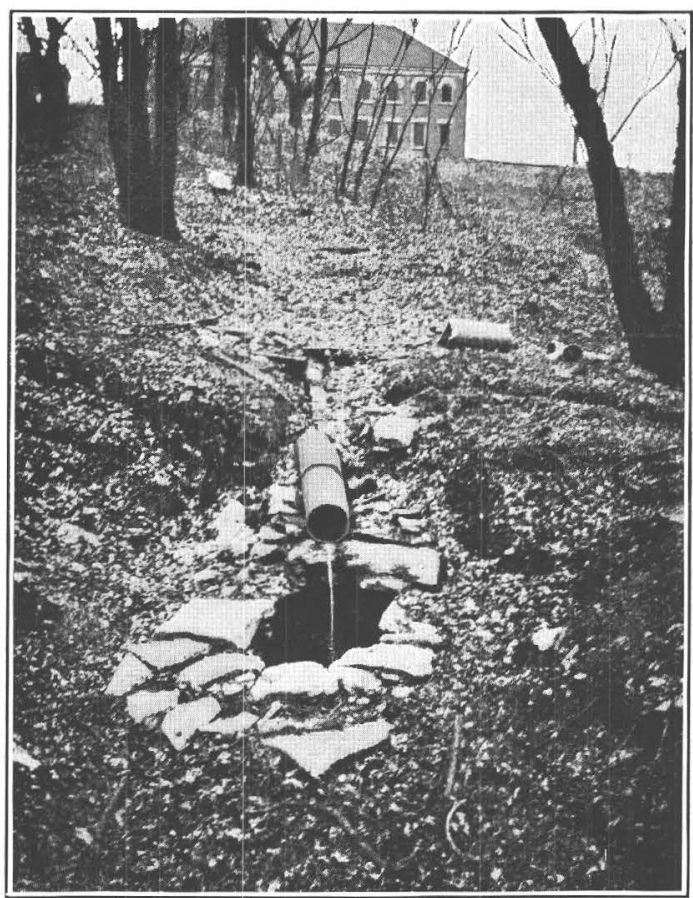

A. POLLUTION OF GROUND WATER: SEWAGE DISCHARGING INTO SINK-HOLE.

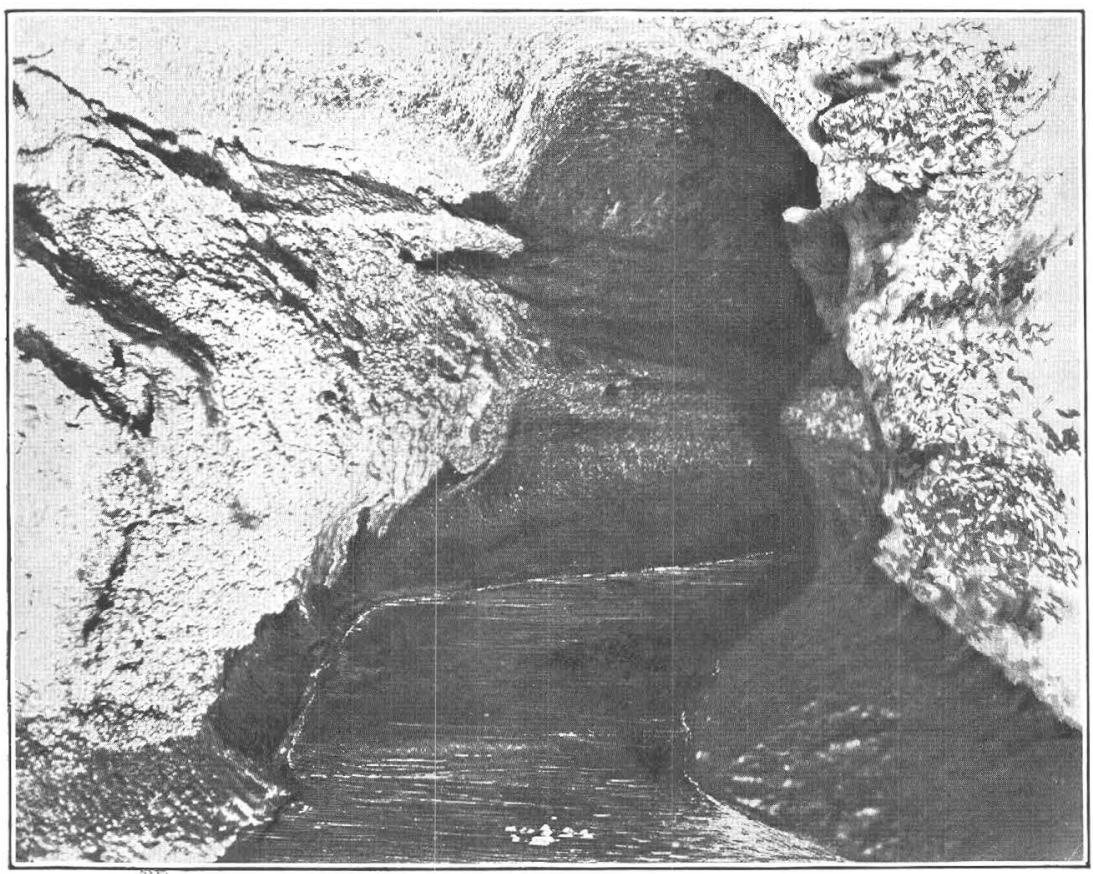

B. OCCURRENCE DF GROUND WATER: LIMESTONE CHANNEL. 
continue so for long distances, as little natural filtration takes place, because of the nature of the channel. (See fig. 9.) The water from till should be thoroughly tested by a bacteriologist if there seems any likelihood of contamination.

Sandstone, conglomerate, and quartzite.-The waters in these materials are very rarely polluted, owing in the more porous varieties to the natural filtration and in the compact varieties to the difficulty with which contaminated waters penetrate them. In quartzitic rock,

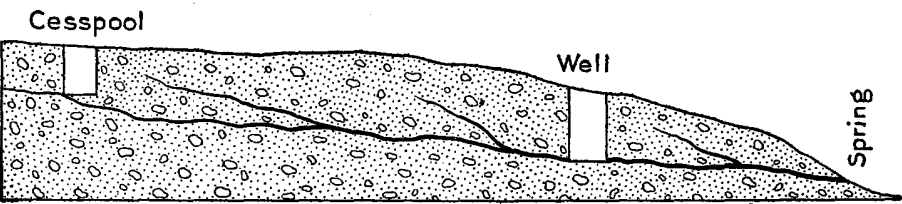

FIGURE 9.-Diagram showing possibility of pollution of wells and springs by material conducted from cesspool through tubular water passages in till.

however, joint fractures may admit both water and polluting materials from the surface.

Shale and slate.-Like the waters of clays and for the same reasons, the waters of slates and shales suffer very little pollution.

Limestone.--In the vicinity of buildings or settlements the waters of limestone are frequently contaminated and unfit for use. This is not because of the amount of lime dissolved, but because of the fact that the water falling on the surface as rain often plunges directly through basins or sinks into the underground channels instead of slowly filtering downward through the soil and into the rock, as in most other materials. This water carries with it the impurities washed or otherwise brought to the sink and bears them along

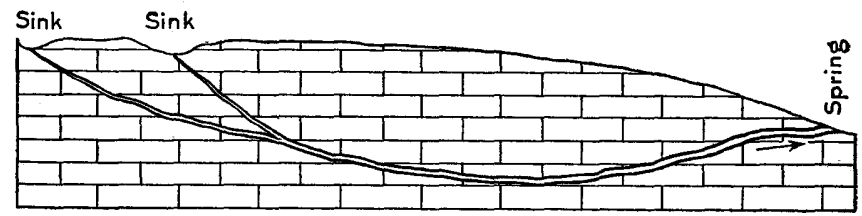

FIGURE 10.-Limestone passage connected with sinks.

through underground passages to distant points. (See fig. 10.) It is a common practice to dump manure, sewage, and other refuse into these sinks, regardless of the fact that it will eventually enter the underground water body. Fortunately in the United States many limestone regions are thinly inhabited, so the danger is not perhaps so widespread here as elsewhere. When springs which have been guarded from surface wash become muddy after a rain it is safe to assume that surface impurities have had access to the ground $46449^{\circ}-$ W s P $255-10-2$ 
water through the sinks or otherwise, and such waters should be avoided.

Granite, gneiss, and schist.-The joints in these rocks generally occur in complex systems of intersecting planes, and it is possible for polluted water starting very near the mouth of the well to pass in a zigzag course downward along the joints, finally reaching the well at a depth of many hundred feet (fig: 8); such was the case in a well. at Atlanta, Ga., which finally had to be abandoned. For this reason wells drilled in broken and jointed igneous rocks in cities and other thickly populated regions are liable to pollution. Waters from such wells, if they are to be used for drinking, should be tested occasionally to determine whether they are polluted or not.

\section{COMMON SOURCES OF WATER.}

The sources of the water used on the farm are numerous-lakes, streams, springs, drilled, bored, driven, and dug wells, and cisterns all being extensively used, although the water from lakes and streams is generally used only for stock. Each of these sources under some conditions may yield entirely safe and satisfactory supplies, while under other conditions certain of them may be a constant menace to the health.

Lakes and ponds.-The waters of lakes and of large ponds, which here include all fresh-water bodies half a mile or more in diameter, are generally good, except when they are polluted by the drainage or sewage from cities or large towns on their shores or on the lower courses of tributary streams. In ponds and in the smaller lakes such pollution may render the entire body of water unsafe for domestic use.

Sunlight, however, has a marked purifying action, tending to destroy the dangerous germs, while, under the action of winds, wave action and circulation are induced in the water, favoring aeration (mixture with air), which, by oxidation, likewise helps to remove the dangerous impurities. At the same time the heavier sediment brought in by the streams is constantly settling to the bottom. As a result of all these processes of purification, the water which entered in a polluted state may at last become so changed that on leaving the lake at its outlet it is both palatable and wholesome.

So rapidly has this purifying action been supposed to take place that before the construction of the Chicago drainage canal it was thought safe by some to draw the supply of the city from Lake Michigan at a distance of only a few miles offshore. Experience proved, however, that while noticeable pollution was confined to a relatively small portion of the lake, and while normally the city supply was fairly safe, it was, nevertheless, under certain conditions of wind and currents, liable to pollution. It was thus necessary either to remove the intake to a point several miles farther away or to divert the sew- 
age from the lake. The Chicago drainage canal, by diverting the sewage, has done much to solve the problem.

Natural lakes are confined almost wholly to the northern portion of the country, where they form a belt extending from eastern North Dakota to eastern Maine. In this belt, besides the Great Lakes, there are tens of thousands of smaller lakes, Minnesota alone having several thousand.

Most of the lakes, especially the smaller ones, are in thinly inhabited regions and afford supplies of high purity. Unfortunately, however, owing to the fact that farmhouses, even if in the vicinity of lakes, are usually placed on high ground at some distance from the water it is necessary, if the lake is used as a source of supply, to haul the water required for domestic purposes. Because of the inconvenience thereby entailed few of the lakes are used, although they constitute ideal supplies for horses and cattle and furnish pure water to those cities which lie within convenient piping distance from them.

In the smaller water bodies, varying from mere pools to lakelets several acres in extent, there is less dilution of the impurities washed into them than in the lakes and large ponds, and even where there are both an inlet and an outlet there is often a tendency for the main current to pass directly from the inlet to the outlet without mixing with the water as a whole, the greater part of the lake thus remaining relatively stagnant. The entrance of a very slight amount of polluting matter into such waters may dangerously affect their quality.

Owing to the slight circulation in these small bodies of water decaying leaves and twigs will frequently accumulate and, together with the growth of water organisms, will give the water an amber or even a dark-brownish color and a noticeable taste. Such coloration does not make the water dangerous any more than the green algous slime that collects on the surface (most of which is perfectly innocent), but both are indications of stagnant conditions that are repugnant to the mind and may mask dangerous impurities. On the bottoms of ponds of this sort there are usually accumulations of decaying vegetable matter mixed with silt, which are very objectionable in water to be used for drinking. It is such accumulations which give off the bubbles of gas that may be seen rising to the surface when the bottom is disturbed.

Not all small ponds, however, shouid be condemned because of their size. Many are fed by springs, are free from pollution, and contain water as clear and cool as could be desired. Such ponds may be used to advantage for domestic supplies, although as the farmhouses are usually situated at a distance from the water they are seldom used except for watering stock.

In some of the prairie and semidesert regions, where streams are relatively few in number or even absent over large areas and where 
wells do not yield sufficient supplies, water is often obtained from artificial ponds. These are usually formed by throwing up a low embankment across some shallow depression or flood-water channel, behind which the rain water or the brief flood flow accumulates. Such reservoirs are commonly but a few rods in diameter and a few feet in depth. As a consequence the water becomes heated in summer, is usually kept constantly muddy by the movements of stock, and is highly polluted by them. (See Pl. VII, B.) As numerous animal diseases may be communicated through drinking water, small ponds of this sort may become a source of great danger.

Many of the water pockets or "tanks" of the deserts, in part natural and in part artificial, are also entirely unsafe even for stock use, although as they constitute the only source of water in many regions such use is unavoidable. In fact, the upbuilding of considerable grazing industries has been made possible by such water pockets in otherwise waterless regions.

Streams.-Over a large part of the country streams and rivers form the most available sources of supply, and in thinly settled regions they are usually free from contamination, although even here a tan-bark plant or sawmill may lessen the desirability of the water for domestic purposes.

Mines, especially coal mines, may likewise discharge their drainage of acid and otherwise polluted waters into the streams with similar effects, but the most common source of pollution is the sewage from towns and cities. In fact, practically all the larger streams, and even many of the smaller ones, are highly polluted by such sewage or by refuse from various manufacturing plants. It is true that such streams become gradually purified and under ordinary conditions may be fairly safe, but the periodic outbreaks of typhoid fever that occur among the users of their water are sufficient to indicate the imperfect nature of this purification.

Large cities without other accessible sources will doubtless continue to use river waters, but these waters are now, as a rule, scientifically filtered before distribution. On most farms, however, other and safer sources are available, and stream waters which are known to have received drainage or sewage from any source should not be used for drinking. (See Pl. VII, A.) In the larger streams the pollution is rarely high, and many of them will afford satisfactory supplies for stock.

Springs.-Dprings usually form an ideal source of farm supply. Occurring in great abundance in many of the thinly settled regions and coming from considerable depths within the rock or filtering from sand or gravel, they are almost always free from pollution except where buildings are situated on the hillsides above them or where surface wash is allowed to enter them. 


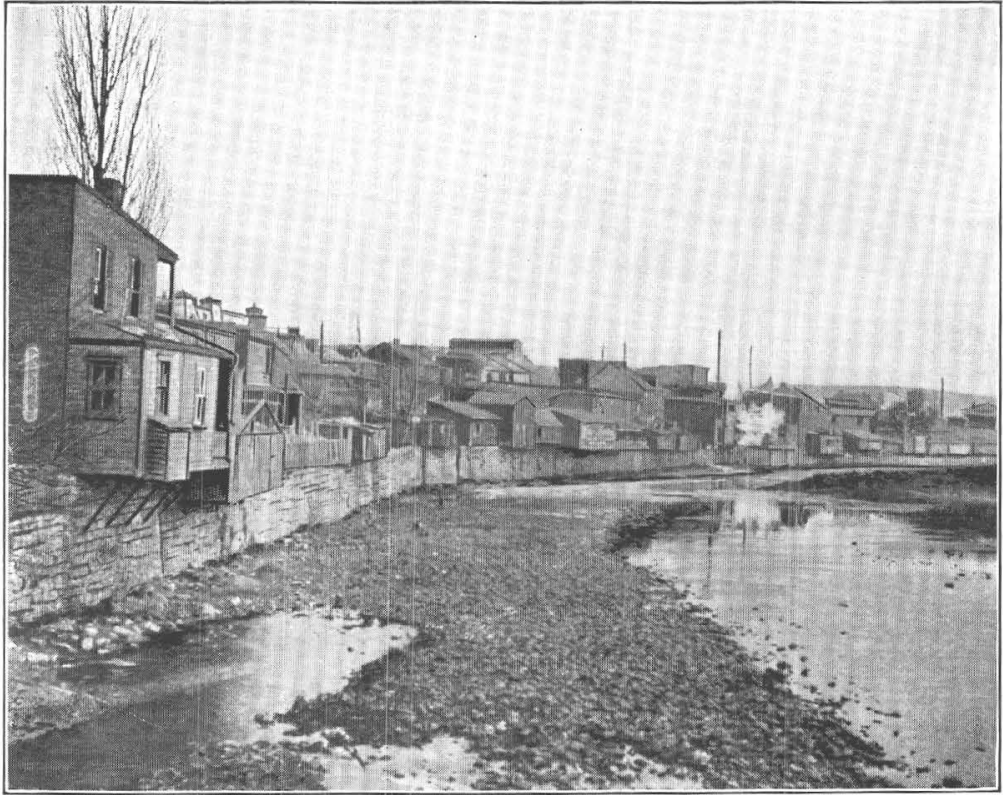

A. OUTHOUSES ALONG STREAM.

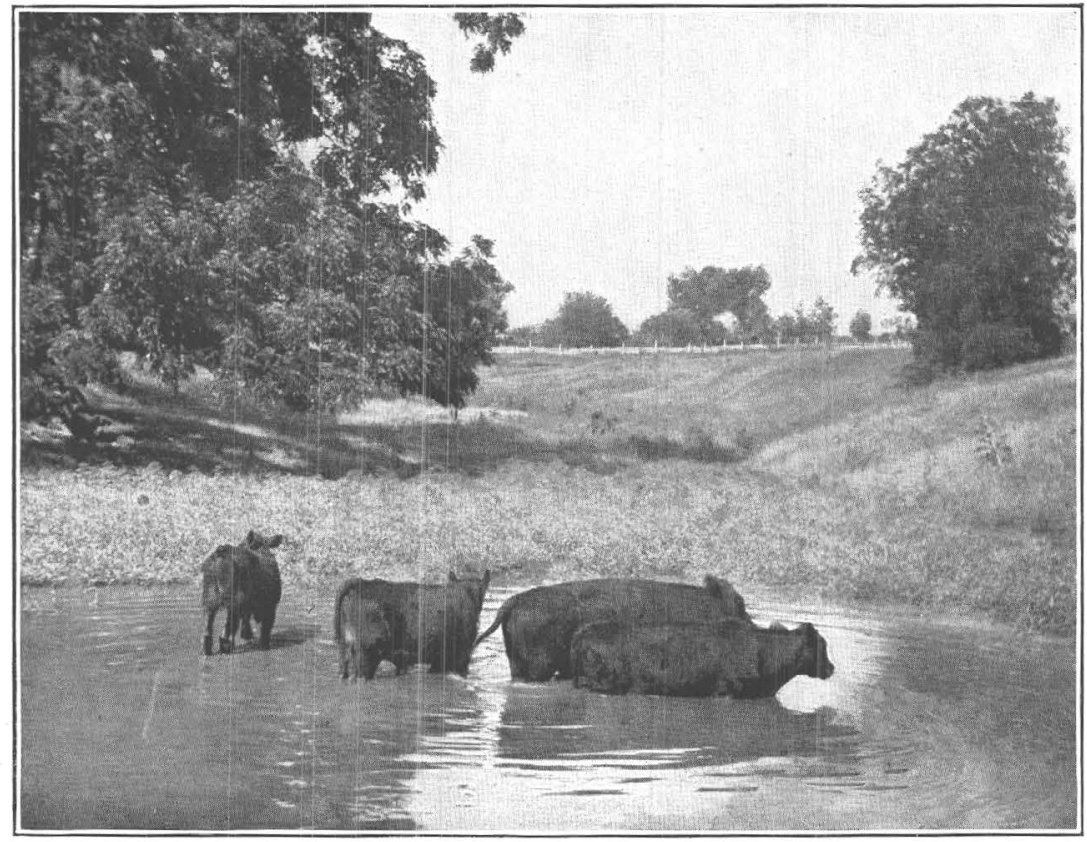

B. STOCK IN POND.

POLLUTION OF SURFACE WATERS. 
In the more hilly regions, such as those of New Hampshire and Vermont, especially where the farms lie in the valleys, the water from hillside springs can usually be piped with little difficulty to the house and barn, where it flows as a steady stream under the influence of gravity alone. A farm supplied from such a source is fortunate indeed.

Natural spring water is almost never dangerous to health, as the minerals it contains in solution are generally harmless, although a few waters act as a physic and others may contain sulphur gases in disagreeable amounts.

Wells.-Dug wells, because of the ease with which they may be constructed by the farmer himself when other work is not pressing, require little money outlay and are therefore very popular. As commonly sunk, however, they are the most dangerous of all sources of water, but with certain precautions, discussed elsewhere (p. 44), they may be made to yield satisfactory supplies.

Driven wells consist of iron pipes, equipped with point and strainer at the end, which are forced into the ground by blows on the top of the pipe. The joints are water-tight; hence the polluted waters near the surface can not possibly enter. Such wells are also very cheap and, in fact, possess advantages which make them most desirable. The fact that they can be put down only in soft materials, where no very hard beds or large bowlders are to be encountered, however, limits their use.

Drilled wells, usually from 2 to 12 inches in diameter, are sunk by machinery in materials too hard or too irregular to permit driving or in places where greater depths are required than can be reached by driving. In all soft materials which will not stand by themselves, or in material through which undesirable water might enter, an iron pipe, known as the "casing," is inserted, shutting off all impurities. Drilled wells are usually of considerable depth, some of them being carried to 2,000 feet or more if water is not found at higher levels. In granites and similar rocks most of the water is found within 300 feet of the surface, and if a supply is not obtained within that depth it is better to start a new well than to drill the old one deeper.

The chief disadvantage of such deep waters is the large amount of mineral matter which they may contain and which makes them unfit for boiler and manufacturing purposes. But to the farmer this feature is usually of no consequence. To him the principal question is the cost. The deeper wells are of course usually beyond his reach, but fortunately water can often be found relatively near the surface. Moreover, such waters, contrary to the common belief, usually contain less mineral matter than the deeper waters and can often be obtained in larger amounts. 
Cisterns.-Where a satisfactory supply can not be obtained from the ground, or where the ground water is hard and soft water is required for certain purposes, the rain falling on the roofs of the farm buildings is often utilized. It is conducted by pipes to shallow welllike excavations, which are commonly made at least approximately water-tight by linings of cement or other impervious material. When thus made they are generally safe to use, and the waters, being very soft, are highly prized for domestic purposes; but if cracks allow the outside waters to enter, cisterns are as liable to contamination as dug wells.

Summary.-Of the various sources of water supply the ground water is the most satisfactory for farm use, because it is least liable to pollution, and streams and ponds are the most unsatisfactory, because of the ease and frequency with which they are contaminated. Fortunately, however, the latter are very seldom used for drinking and domestic purposes, being utilized mainly for stock, on which the effect of moderate pollution is not apparent. The underground supplies, whether from wells or springs, although safe in many localities, are far from being universally so, the safety depending mainly on their location and on the nature of their protection. These are discussed in the following sections.

\section{UNDERGROUND WATERS AND THEIR PROTECTION.}

\section{SPRINGS.}

The term "spring" is properly applied to the water emerging from the ground at a single point or within a restricted area. The distinction between springs and general seepage, however, is not always very sharp, for there are all gradations between the concentrated outflows characterizing true springs and the diffused emergence of water over large areas or beneath the level of the water in streams.

Springs may be divided, according to their mode of origin, into gravity and artesian springs, and, according to the nature of the passages traversed by the water, into seepage, tubular, and fissure springs.

\section{, KINDS OF. SPRINGS.}

Gravity springs.-A gravity spring is one whose water is not confined between impervious beds but flows from loose materials or open passages under the action of gravity, just as a surface stream flows down its channel. The conditions are shown in figure 11 .

Artesian springs.-An artesian spring is one whose waters are confined in impervious channels or between impervious beds and are under hydrostatic pressure because the water level at their source is higher than the point where they emerge. The waters of such a spring, if confined in a pipe instead of being allowed to flow out upon the ground, may rise considerably above the spring mouth. 
Seepage springs.-Seepage springs are springs in which the water seeps out of sand or gravel; they differ from general seepage only in being restricted to a small area. Such springs are usually marked - by abundant vegetation at their points of emergence, and their waters are often colored or carry an oily scum due to the decomposition of vegetable matter or the presence of iron. The scum is frequently mistaken for petroleum. The waters of the seepage springs commonly come from no great distance beneath the surface and are not usually very cold.

Seepage springs may emerge along the top of an underlying impervious bed, but more commonly they occur where valleys are cut downward into the zone of saturation of a more or less uniform waterbearing deposit. Under favorable conditions the seepage from sands, as on Long Island, New York, gathers into channels and forms streams of considerable size, some of them flowing 5,000,000 gallons or more daily.

Seepage springs, as in the cases cited, are commonly of the gravity type, but where channels or fissures emerge beneath beds of sand or gravel seepages not infrequently result from true artesian springs.

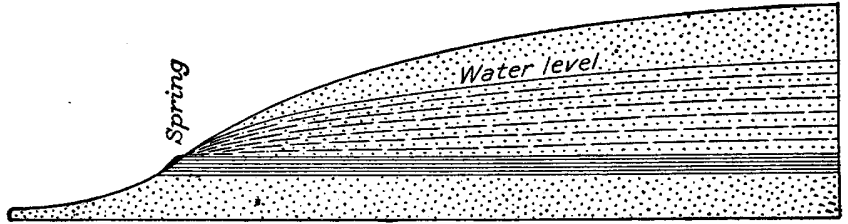

FIGURE 11,-Spring fed from unconfined waters in porous sands.

Tubular springs.-Tubular springs embrace a great variety of flows, including both those in the small more or less tubular passages in the drift and those occupying large solution channels or caverns in the soluble rocks.

The channels of springs in the drift are generally established along some more or less sandy or other porous layer, or perhaps along the path left by a decaying root. The motion at first appears to have been mainly that of seepage, but in many springs a passageway has been gradually opened, along which a definite stream finds its way. The waters reach the channels by percolation through the clays and sands and are usually free from pollution except when near cesspools or vaults sunk some distance into the ground.

In limestones and other soluble rocks the underground passages may reach many miles in length. Single passages, as in the Mammoth Cave of Kentucky, have been traversed for a distance of nearly 10 miles, and passages several times as long, though as yet undiscoviered, probably exist. Some of these passages are many feet in diam- 
eter and are traversed by streams of considerable size, or even by rivers. The Silver Springs of Florida give rise to a river which is navigable from the ocean to its source in the springs, and springs of similar volume occur at other points in Florida and Arkansas and possibly elsewhere. The waters of such springs vary greatly in composition, although most of them are hard. In some springs the waters are exceedingly clear, the bottoms being distinctly visible at a depth of many feet, but in others the waters are muddy after severe storms. When clear it is probable that the waters feeding the underground stream reached it by percolation through the porous earth or rock, during which its impurities were largely removed. When muddy the waters in part appear to have penetrated downward through sinks or to have entered the rock directly as streams; in either case they are very liable to pollution by impurities washed in with the water.

Tubular springs are most commonly of the gravity type, the channels generally sloping from higher to lower levels. In both drift and limestone, however, there are numerous exceptional springs whose channels are at some points in their courses considerably lower than

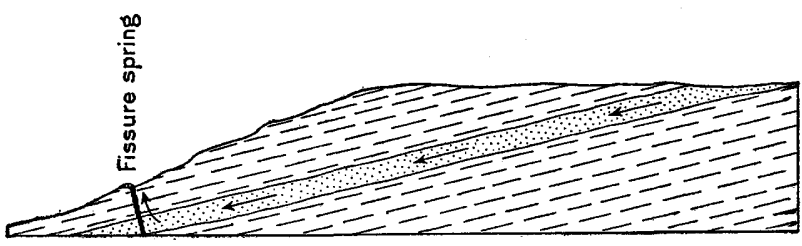

FIGURE 12.-Fissure spring.

their outlets. Under such conditions the water may be under considerable artesian pressure in the lower parts of its channel or even at its outlet.

Fissure springs.- The term fissure spring is here used rather comprehensively to include the springs issuing along bedding, joint, cleavage, or fault planes. (See fig. 12.) The distinguishing feature is a break in the rocks along which the waters can pass, it being immaterial whether any considerable open space exists. These springs differ from tubular springs in that they are as a class of deeper-seated origin, as is attested by their temperatures. The waters are almost never subjected to contamination, though in many springs they are highly mineralized. Springs of this class are of ten distributed along straight lines for considerable distances, their position being determined by lines of fracture or jointing.

\section{SAFETY OF SPRINGS.}

Springs from sands, sandstones, clays, shales, and slates are seldom polluted, except where contaminating matter penetrates through 


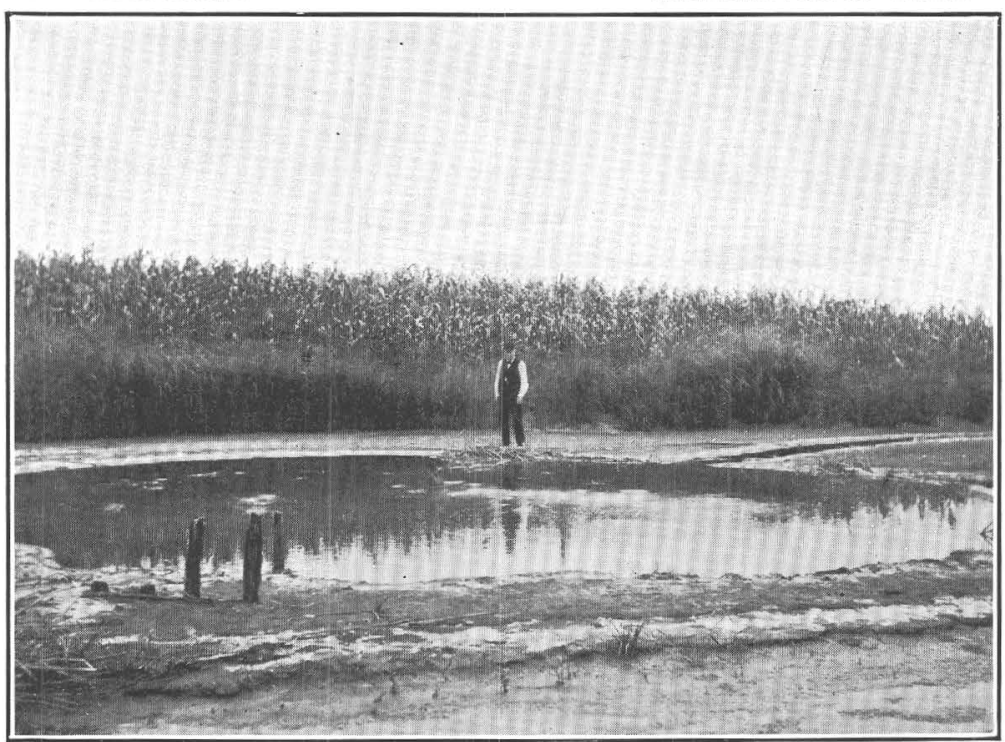

A. SPRING RECEIVING WASH FROM FERTILIZED LAND

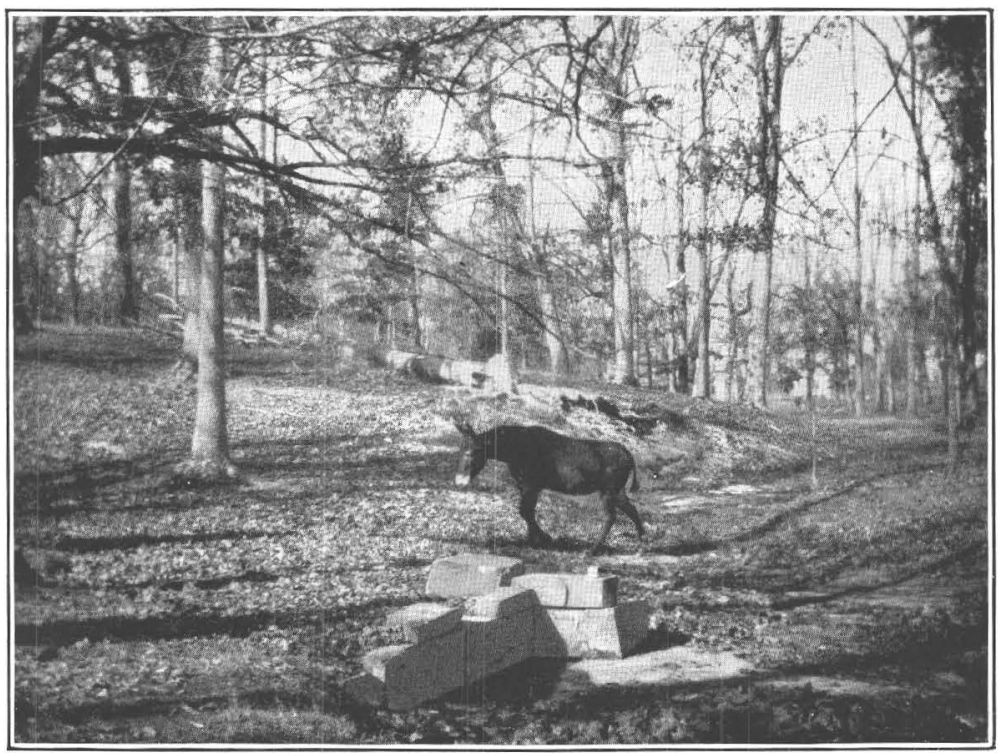

B. SPRING RECEIVING POLLUTION FROM STOCK AND SURFACE WASH.

$$
\text { POLLUTION OF SPRINGS. }
$$




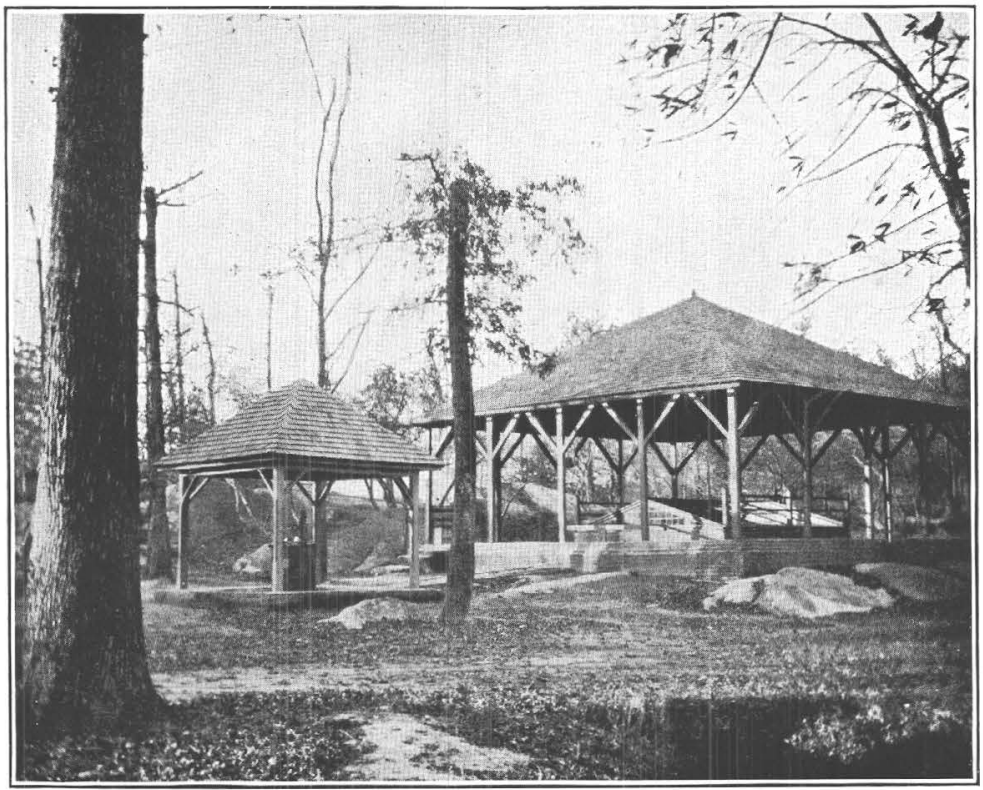

A. PROPERLY PROTECTED SPRING.

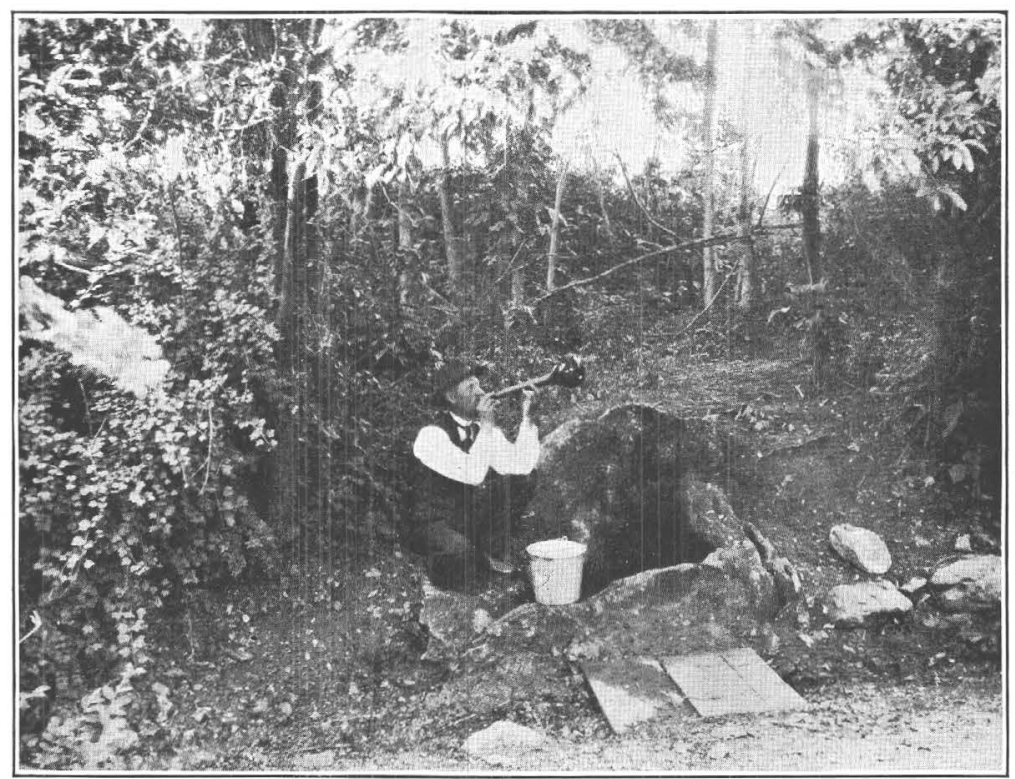

B. SPRING open to falling Leaves, etC.

POLLUTION OF SPRINGS. 
eracks or fissures, or through the material itself where the covering above the water is very thin. Usually such pollution is likely to occur only where houses, barns, sewers, or cesspools are located on higher ground near the spring, or more especially where cities or towns are so located. In limestones, on the contrary, sewage or other polluting matter frequently enters the underground channels through the sinks (Pl. VI, $A$ ) and may contaminate the underground water for long distances. Similarly in the tubular channels in the till, if material from a cesspool or other source of pollution finds access, the water may retain its contamination for a long period and a great distance.

\section{PROTECTION OF SPRINGS.}

Protection from stock.-One of the most common causes of contamination of springs in the farming districts arises from failure to fence the springs to prevent the access of stock. Plate VIII, $B$, shows a mineral spring in Georgia from which many people drink and from which the waters have at times been shipped, but about which stock are nevertheless allowed to roam freely, drinking from it at will and incidentally contaminating it in a variety of ways. It is needless to say that any spring used for drinking water should be carefully fenced at such a distance as to prevent any excrement from reaching it.

Protection from surface drainage.- The spring mentioned above is located only a few inches above the bottom of the stream channel shown on the right of the view. When the picture was taken no water was flowing in the channel, but at times of rain considerable volumes of water descend along the depression, covering the spring and washing into it all sorts of refuse from the hillsides above. Plate VIII, $A$, shows another spring, located in Missouri, receiving the drainage from a cornfield, together with such manure or other fertilizer as may be used in the cultivation of the crops. This water, which carries both sulphur and Epsom salts, is considered of medicinal value, but it is clear that, situated as it is, its safety is at least doubtful.

In general, it is not advisable to use springs for drinking water where their location normally exposes them to inflows of surface drainage. If other sources are not available, however, the spring should be carefully protected by impervious walls, which should be carried to sufficient height to keep out the surface water. An example of a spring protected from all such sources of pollution is afforded by the Bowden lithia spring, at Austell, Ga., shown in Plate IX, $A$.

Protection from wind blown and other refuse.-Another source of frequent and objectionable though not necessarily dangerous contamination is the leaves, paper, dust, and dirt blown into open springs by the wind. The spring shown in Plate IX, $B$, is a typical example of those surrounded by thick vegetation, and especially 
liable to contamination by leaves and forest litter. An example of danger from refuse of a more disgusting type is shown in Plate X, $A$. Located in the middle of a well-traveled street, only a few inches above a gutter filled with paper and refuse, a part of which is sure to enter whenever a heavy rain occurs; open to the rain which washes into it from the steps leading down to it such dirt from the street as is brought in by the feet of the users; subject to the dipping of all sorts of more or less dirty buckets and utensils; receiving the underground drainage and presumably more or less sewage from the buildings on the slopes above; and containing in its bottom several inches of decaying paper and other refuse, this spring is on the whole one of the worst and most dangerously located sources of drinking water in the United States.

Protection from subsurface drainage.-In farming districts pollution by subsurface drainage from buildings on the slopes above the springs is not very common, although many springs are located back of barns, below hogpens and outbuildings. The placing of buildings above springs intended for use should always be avoided, even if

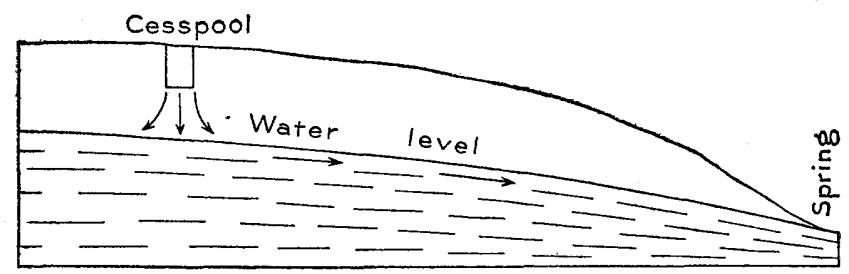

FIGURE 13.-Diagram showing manner in which springs may be polluted by subsurface drainage.

the spring is several hundred feet away from the proposed site. (See fig. 13.)

Protection of sink holes.-It has already been pointed out that much of the water in limestones, the springs of which are frequently used for drinking and domestic purposes, enters the rock through open sink holes, into which in some places manure and other refuse has been dumped or sewage drained. Plate VI, $A$, shows a small but continuous stream of sewage from a large college building discharging into a sink from which it finds its way to the underground water channels. Such practices are very dangerous. Cases of typhoid fever have resulted from drinking water from springs or wells wbich have become polluted by such matter entering the sinks; and even where specific pollution is absent, undesirable slimes and rubbish often render the water highly objectionable. Instead of discharging refuse or sewage into sinks, every care should be taken to protect them against its access.

Use of lead pipes.--Spring water should always be conveyed by iron pipes, as lead, which was formerly much used, is more or less 


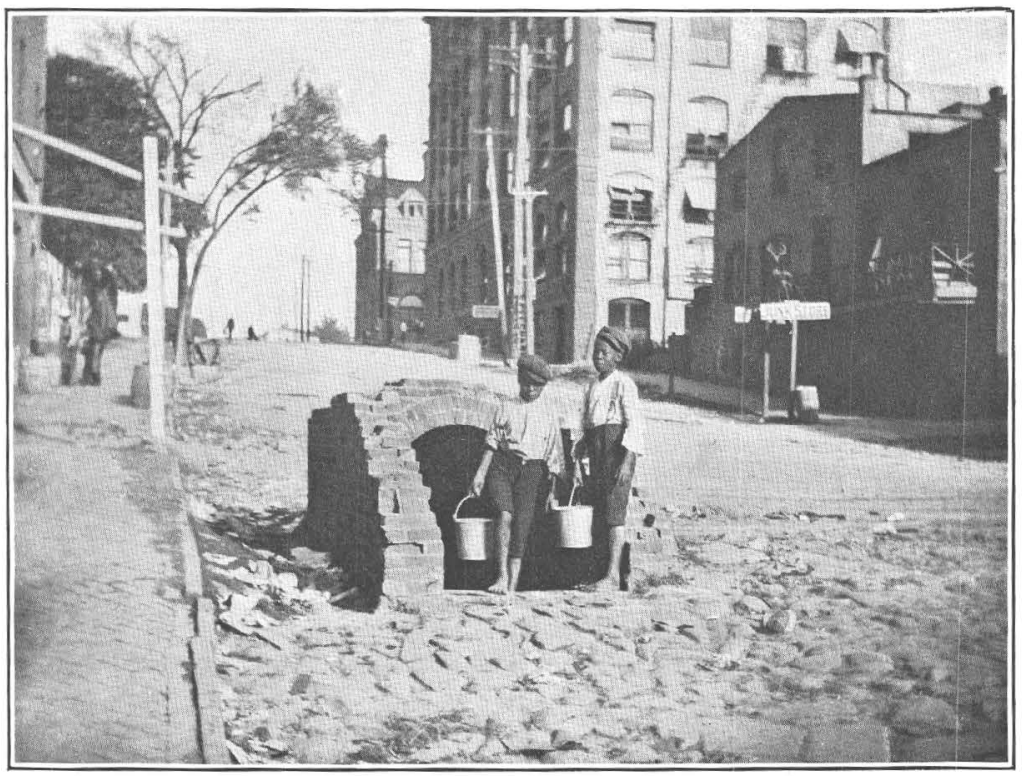

A. SPRING IN CENTER OF CITY STREET.

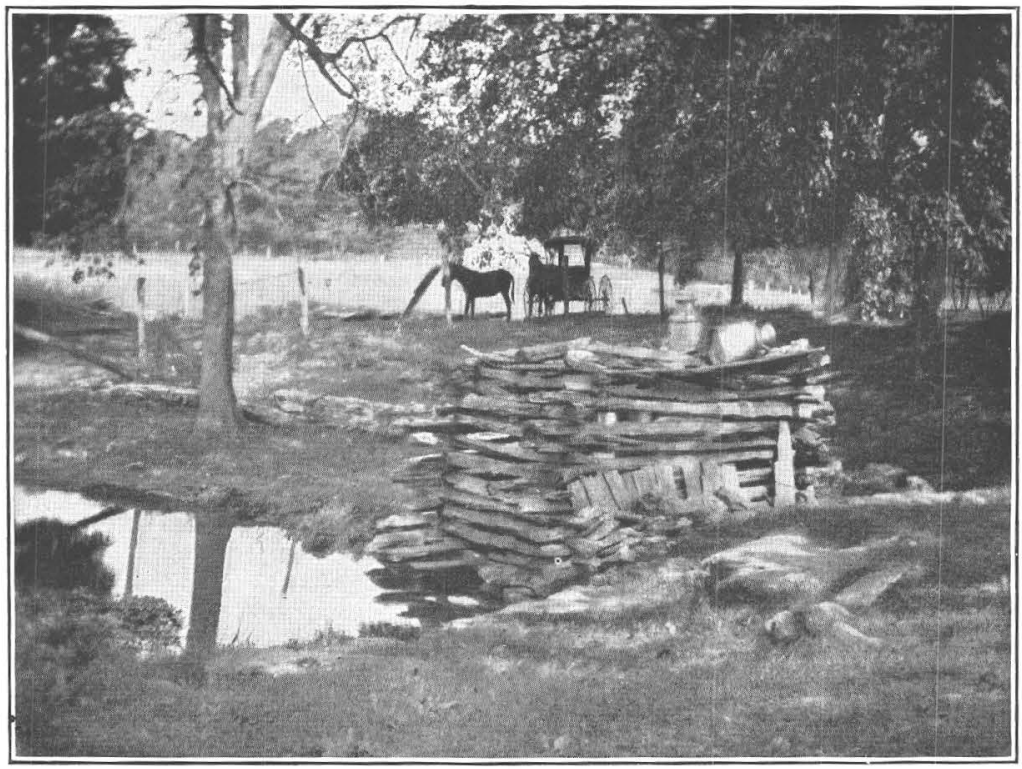

B. DAIRY SPRING FROM POLLUTED UNDERGROUND STREAM.

POLLUTION OF SPRINGS. 
readily dissolved by soft waters. Thousands of cases of lead poisoning resulted from such use in Europe and America before the cost of lead pipes became so high that they were largely abandoned.

Where the water flows continually there is little danger from lead pipes, but if the flow is shut off when not in use, enough water should be drawn off each time to remove entirely that which has been standing in the pipes before taking any for domestic purposes or for the use of stock.

Tests for pollution.-There is no infallible chemical test for the detection of pollution in small amounts. If a chemist is thoroughly familiar with the normal character of water in the immediate vicinity, he may be able to detect contamination by means of chemical examination; but waters contain so many harmless substances dissolved from the earth that the determinations by a chemist are often inconclusive. Careful observation of the spring itself and a common-sense inspection of its surroundings are usually of more value than an analysis. The spring should be protected from pollution, especially from surface drainage from houses, barns, hogpens, and other outhouses that are situated on the slopes above it within a distance of several hundred feet. When the absence of such local sources of pollution is established, the water should be carefully watched, especially in limestone regions, for muddiness or floating matter rising with the water after severe rains. Such phenomena are evidence of connection with sink holes and indicate that the water is to be looked upon with grave suspicion if opportunity exists anywhere within miles for the entrance of polluting matter through sinks or otherwise. Plate $\mathrm{X}, B$, shows a spring in Greene County, Mo., used for dairy purposes. The spring is remote from buildings and the water is clear, cold, and sparkling, but is, nevertheless, more or less polluted, owing to the fact that the underground stream feeding the spring appears at the surface at a number of points above it, crossing one or more highways and receiving the drainage from them and from a cemetery.

\section{WELLS.}

\section{GENERAL DISCUSSION}

Because of their cheapness, convenience, and fancied safety, wells are by far the most popular source of domestic supplies in all regions in which water is found at reasonable depth. If properly located and constructed they afford an ideal source of supply fully justifying their popularity. But if they are carelessly finished or improperly located they are much more liable to pollution than is commonly supposed, and it is with the view of pointing out some of the precautions that should be taken for their protection, "as well as of 
presenting information concerning desirable types, location, and construction, that the following discussion is presented.

TYPES OF WELLS.

Although no two wells are exactly alike in all particulars, there are, in reality, only a few distinct forms, the others being simply modifications or combinations of these. (See PI. XI-XV; figs. 14-16.) The kind of well to be sunk at a particular locality depends mainly on the nature of the material to be encountered, one form being particularly adapted to a certain material, such as sand, while an entirely different form is demanded if rock is to be penetrated. The following tables show clearly and concisely the characteristics and methods of sinking the more common types and point out the conditions to which they are best adapted:

Types of wells and conditions to which they are adapted.

\begin{tabular}{|c|c|}
\hline Type of well. & Description. \\
\hline Dug... & $\begin{array}{l}\text { Generally circular excavations, } 3 \text { to } 6 \\
\text { feet in diameter, dug or blasted by } \\
\text { hand and curbed with wood or with } \\
\text { stones or bricks laid without cement. }\end{array}$ \\
\hline Bored. & $\begin{array}{l}\text { Bored with various types of augers } \\
\text { from } 2 \text { inches to } 3 \text { feet in diameter, } \\
\text { rotated and lifted (together with the } \\
\text { earth) by hand or horsepower. } \\
\text { Curbed with wood, cement, or tile } \\
\text { sections, with open or cemented } \\
\text { joints, and more rarely with iron } \\
\text { tubing. }\end{array}$ \\
\hline Punched.. & $\begin{array}{l}\text { Small holes, usually under } 6 \text { inches in } \\
\text { diameter, sunk by hand or horse- } \\
\text { power, by dropping a steel cylinder } \\
\text { slit at the side so as to hold and lift } \\
\text { material by its spring. Clay is } \\
\text { added to incoherent materials like } \\
\text { sand to bind them together so that } \\
\text { they can be lifted. }\end{array}$ \\
\hline Driven.............. & $\begin{array}{l}\text { Small iron tubes, usually } 11 \text { to } 4 \text { inches } \\
\text { in diameter and provided with point } \\
\text { and screen, driven downward by } \\
\text { hand or by simple hand or horse- } \\
\text { power apparatus. }\end{array}$ \\
\hline California or stovepipe & $\begin{array}{l}\text { Overlapping sheet - steel casings, } 4 \\
\text { inches or more in diameter, forced } \\
\text { downwards by hydraulic jacks and } \\
\text { finally perforated by a special appa- } \\
\text { ratus at water strata. Drillings are } \\
\text { removed by a long sand-bucket with } \\
\text { valve. }\end{array}$ \\
\hline Standard drilled.. & $\begin{array}{l}\text { Sunk by percussion of heavy drill, } 1 \frac{1}{2} \text { to } \\
12 \text { inches or more in diameter, lifted } \\
\text { and dropped from portable rig or der- } \\
\text { rick by horse or steam power. Cased } \\
\text { with iron pipe in soft materials; usu- } \\
\text { ally not cased in rock. Drillings re- } \\
\text { moved by long bucket with valve in } \\
\text { bottom. }\end{array}$ \\
\hline Diamond-drill hole. & $\begin{array}{l}\text { Sunk by rotating hollow bit, usually } \\
\mathbf{1} \text { to } 4 \text { inches in diameter, with rim } \\
\text { fitted with black diamonds. Pene- } \\
\text { trates by abrasion due to rotation. } \\
\text { Drillings removed by water forced } \\
\text { down drill and up along outside of } \\
\text { rods. }\end{array}$ \\
\hline
\end{tabular}

Conditions to which well is best adapted.

Adapted to localities where the water is near the surface, especially where it occurs as small seeps in clayey ma. terials and requires extensive storage space for its conservation. Should not be near sources of pollution.

Adapted to localities where the water is at slight or medium depths and to materials similar to those in which open wells are sunk.

Adapted to clayey materials in which water occurs as seeps within 50 feet of surface, but not at much greater depths.

Adapted to soft and fine materials; especially to sands and similar porous materials carrying considerable water at relatively slight depths. Particularly desirable where upper soil carries polluting matter.

Adapted to soft materials extending to considerable depths and having several water strata capable of utilization.

Can be used to advantage in all but the softest materials, but is particularly adapted to rock work, especially at great depths, being cheaper and quicker than other methods of drilling in rock.

Not adapted to water wells because of great cost. Used where cores of materials penetrated are required, or where hole is sunk at an angle with she vertical. 


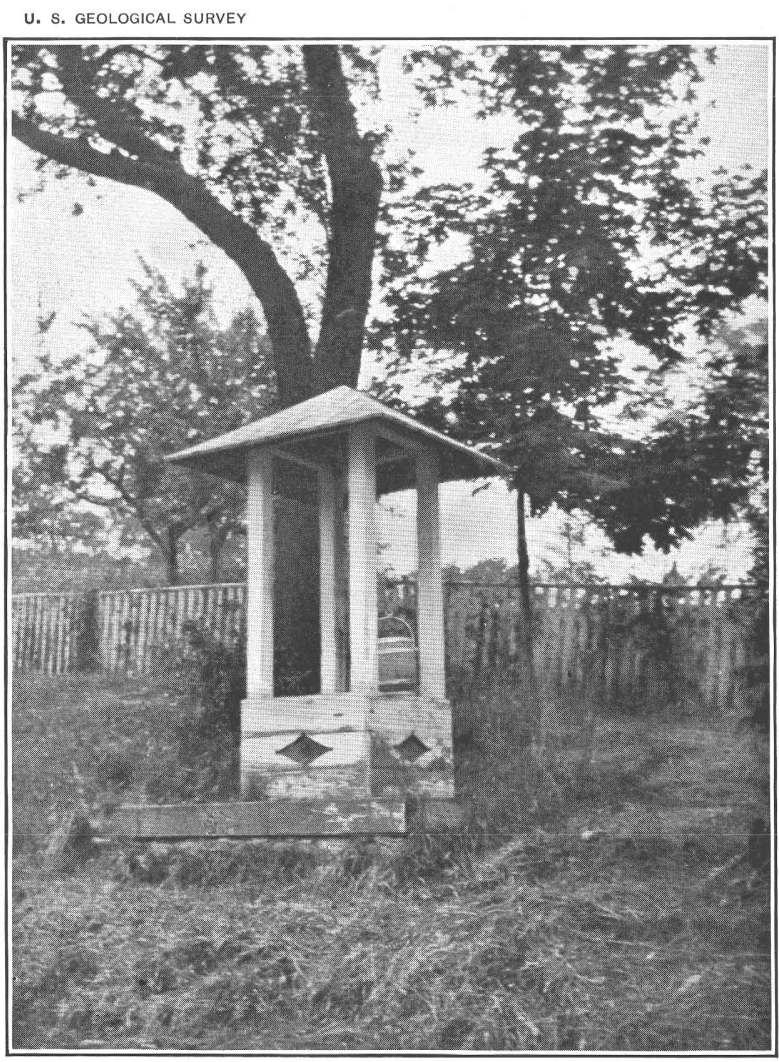

A. OPEN DUG WELL.

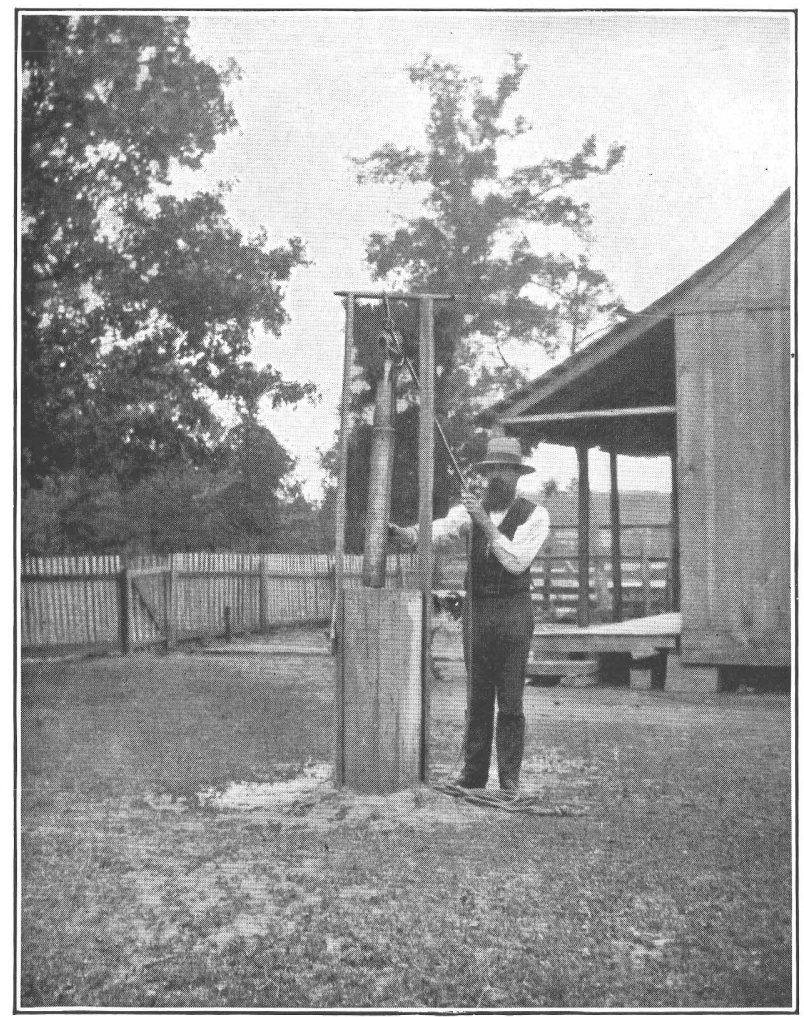

B. BORED WELL. 


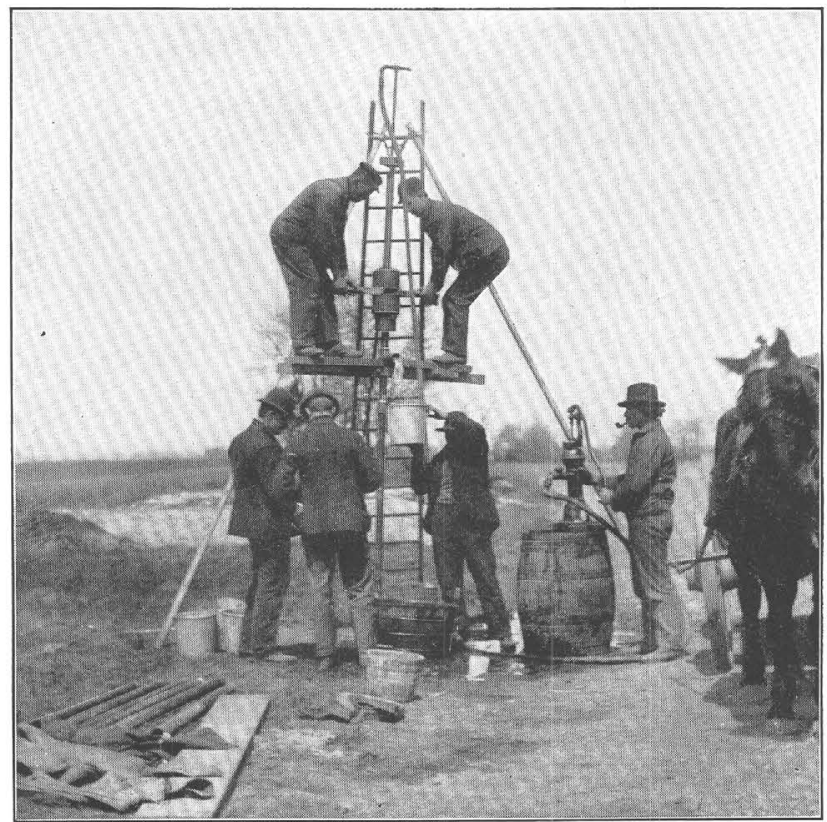

A. THE JET OUTFIT.

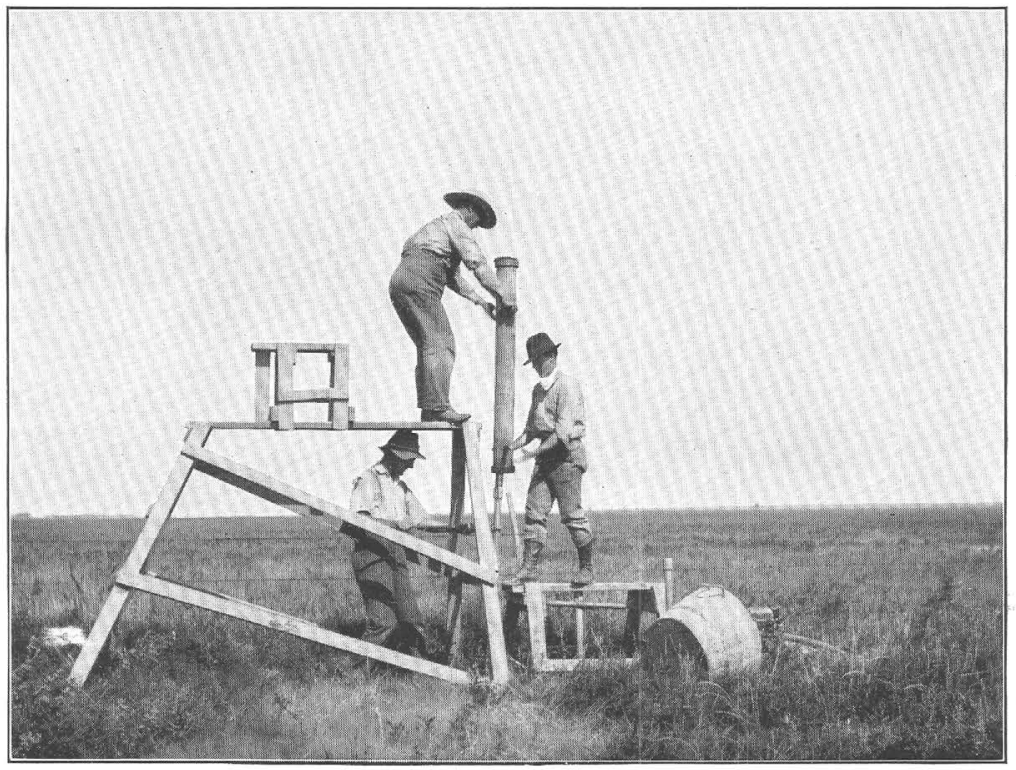

$B$. THE DRIVEN WELL.

METHODS OF SINKING WELLS. 


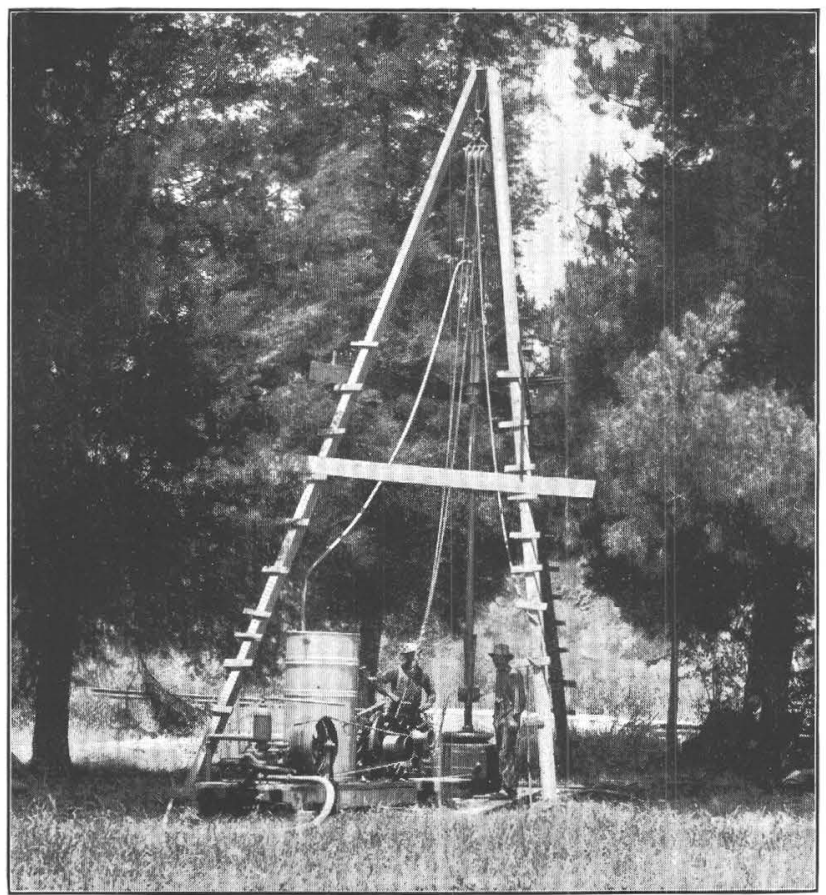

A. STANDARD PORTABLE RIG.

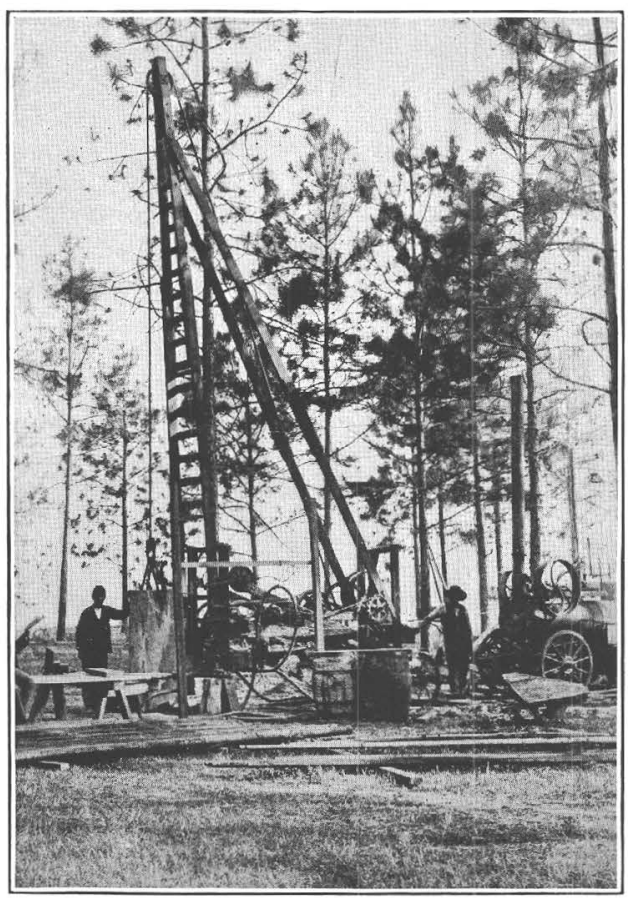

B. ROTARY APPARATUS.

METHODS OF SINKING WELLS. 


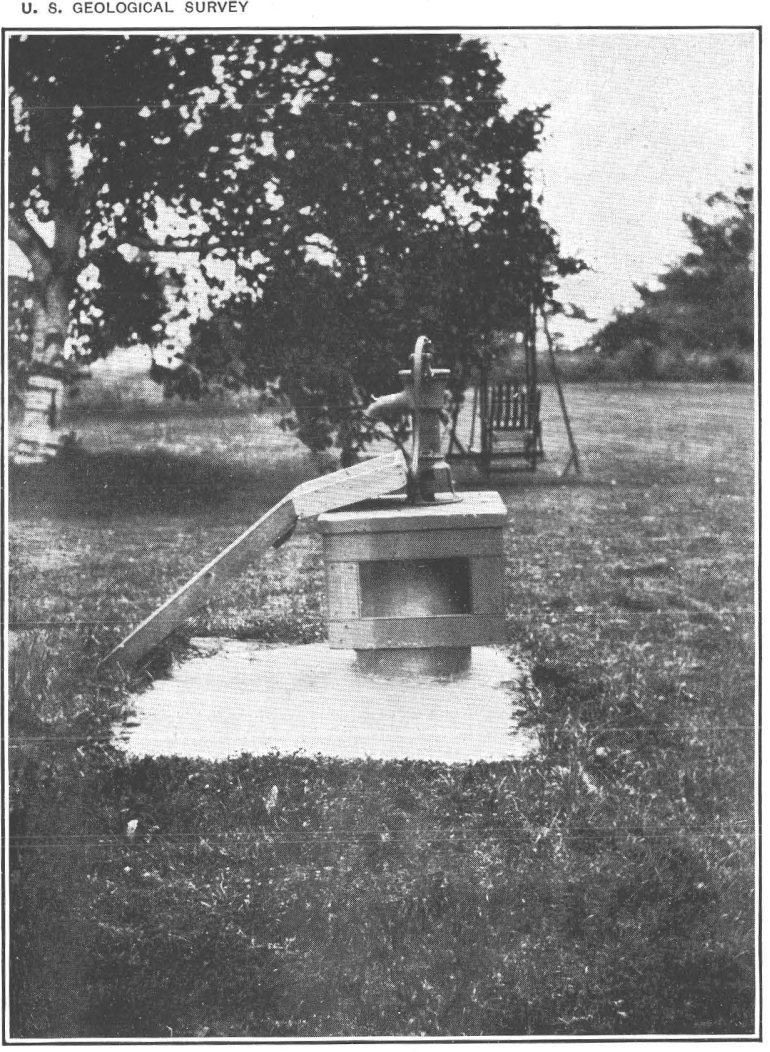

A. PITCHER PUMP.

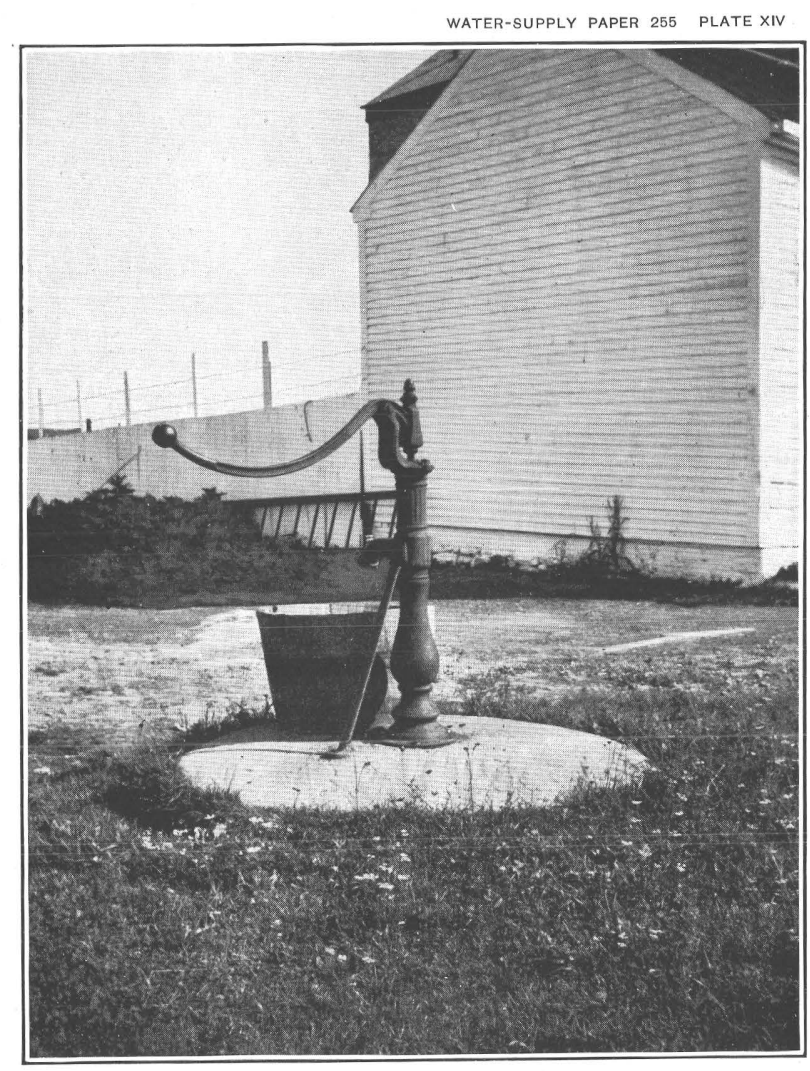

B. DEEP WELL PUMP.

METHODS OF RAISING WATER. 


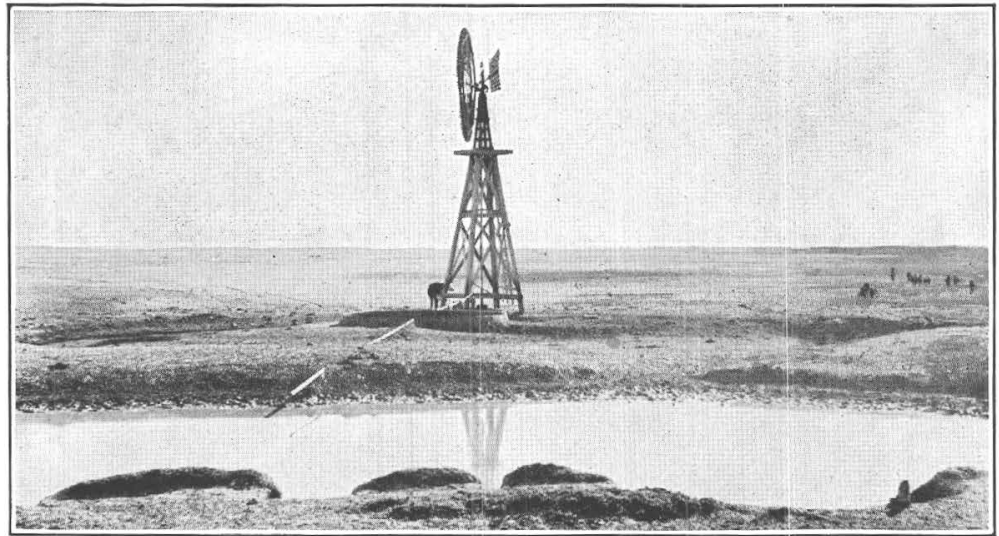

A. WINDMILL.

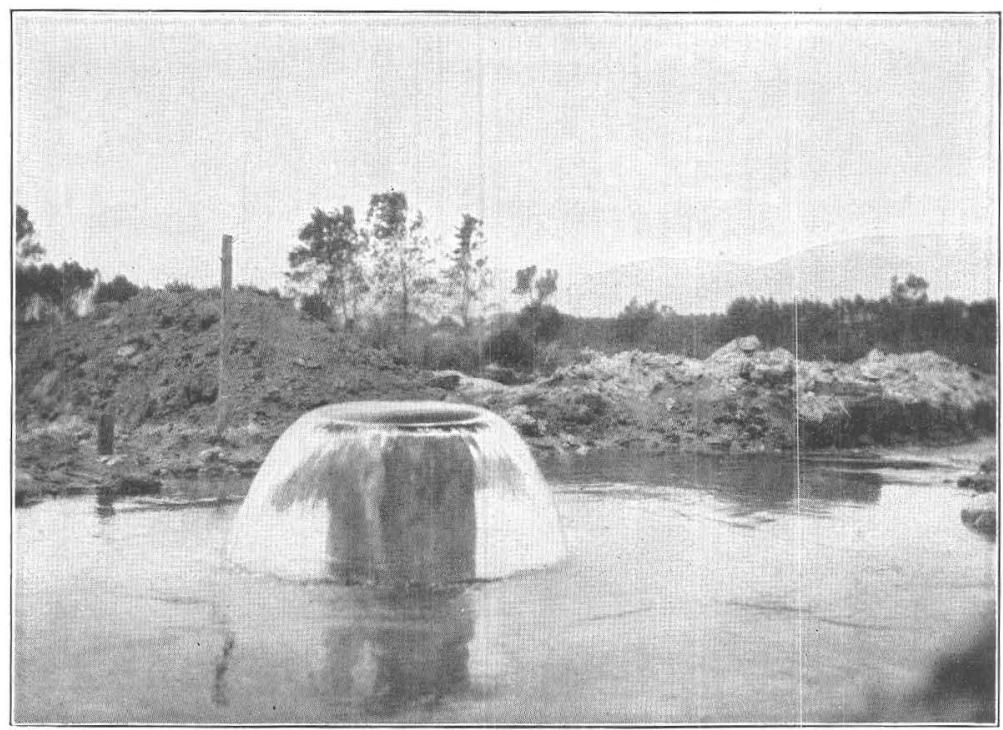

B. NATURAL FLOW.

METHODS OF RAISING WATER. 


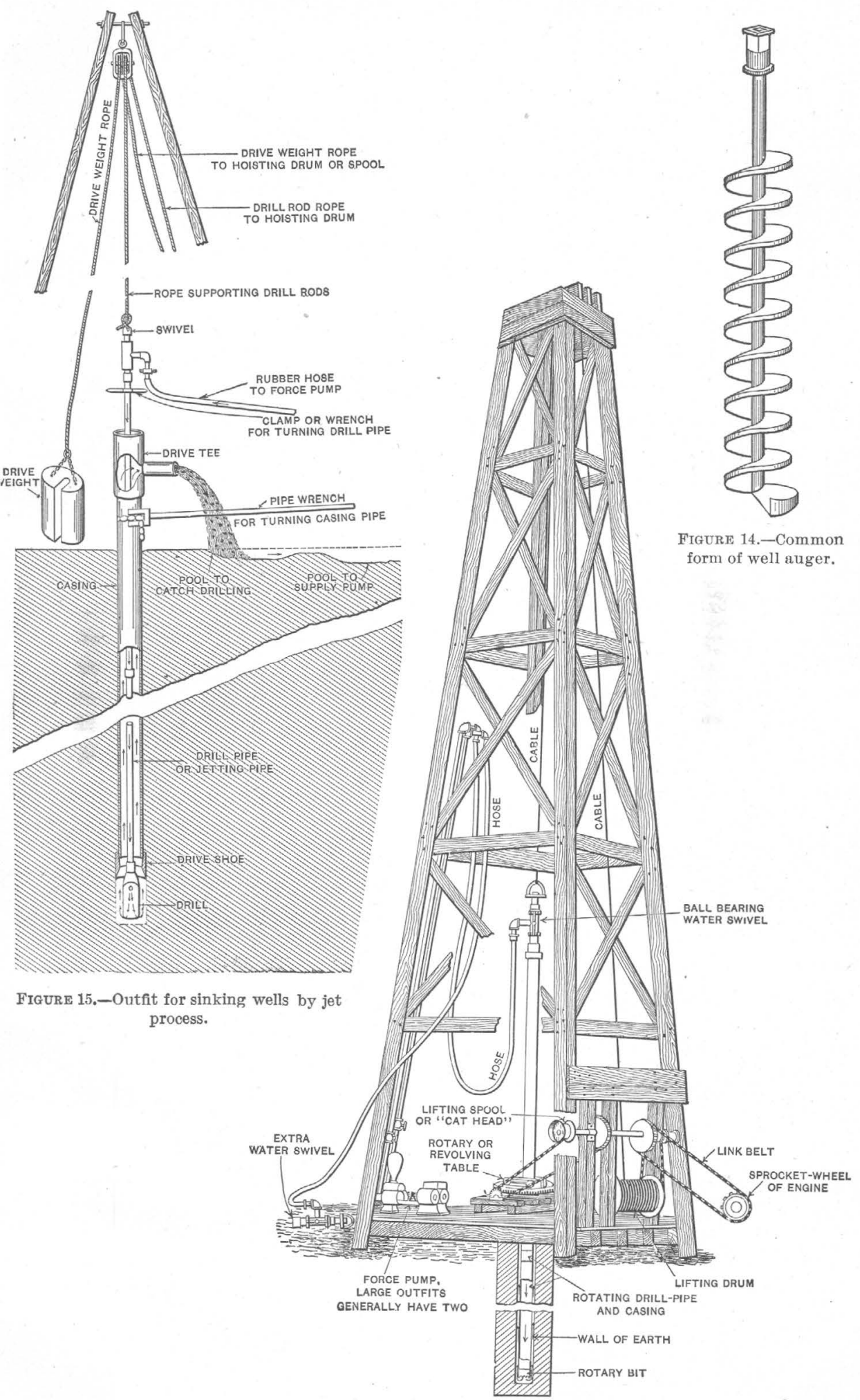

FIGURE 16.-Outfit for sinking wells by rotary process. 
Types of wells and conditions to which they are adapted-Continued.

\begin{tabular}{|c|c|c|}
\hline Type of well. & Description. & $\begin{array}{c}\text { Conditions to which well is best } \\
\text { adapted. }\end{array}$ \\
\hline $\begin{array}{l}\text { Wells sunk by ealyx and } \\
\text { steel-shot methods. }\end{array}$ & $\begin{array}{l}\text { Sunk by rotation of notched steel shoe, } \\
\text { or by chilled steel shot used in con- } \\
\text { nection with a rotating plain shoe of } \\
\text { soft iron. Rods by which power is } \\
\text { transmitted are hollow and permit } \\
\text { the dropping of the shot and the en- } \\
\text { trance of water, which brings up the } \\
\text { cuttings as with the diamond drill. }\end{array}$ & $\begin{array}{l}\text { Adapted to vertical work in hard focks } \\
\text { where cores are required. Cheaper } \\
\text { but slower than diamond-drill meth- } \\
\text { od, and more expensive than stand- } \\
\text { ard drilled holes. Is successfully } \\
\text { used as an adjunct to hydraulic } \\
\text { rotary process. }\end{array}$ \\
\hline Wells sunk by jetprocess. & $\begin{array}{l}\text { Sunk by forcing water down small iron } \\
\text { "jet pipe" inside of casing, the water } \\
\text { rising between the two with the } \\
\text { drillings. Casing sinks by own } \\
\text { weight or is forced down by jacks or } \\
\text { otherwise. Diameter usually } 2 \text { to } 4 \\
\text { inches. }\end{array}$ & $\begin{array}{l}\text { Adapted to soft materials capable of be- } \\
\text { ing readily broken up by the water } \\
\text { jet, especially to sands, etc., carrying } \\
\text { considerable water at relatively slight } \\
\text { depths. This method is an improve- } \\
\text { ment over driven wells, which are } \\
\text { adapted to same conditions, because } \\
\text { it affords samples of materials pene- } \\
\text { trated. Quick and fairly cheap and } \\
\text { especially useful in sinking large } \\
\text { numbers of test wells in adjacent } \\
\text { localities. }\end{array}$ \\
\hline $\begin{array}{l}\text { Welts sunk by hydraulic } \\
\text { process. }\end{array}$ & $\begin{array}{l}\text { Sunk by lifting and dropping drill in } \\
\text { hole full of water. Penetrates by } \\
\text { percussion. Water and cuttings are } \\
\text { forced into hollow rod on down } \\
\text { stroke, being retained by valve. Di- } \\
\text { ameter similar to standard drilled } \\
\text { wells. }\end{array}$ & $\begin{array}{l}\text { Adapted to clays and other unconsoli- } \\
\text { dated deposits and to soft rocks where } \\
\text { depths are moderate and the use of a } \\
\text { heavy drill is not required. }\end{array}$ \\
\hline $\begin{array}{l}\text { Wells sunk by hydraulic } \\
\text { rotary process. }\end{array}$ & $\begin{array}{l}\text { Sunk by rotating steel shoe, as in calyx } \\
\text { method, but with the difference that } \\
\text { whole pipe is turned and water is } \\
\text { forced down phpe and up outside in- } \\
\text { stead of through rods. Steel shot } \\
\text { also sometimes used. }\end{array}$ & $\begin{array}{l}\text { Adapted to rapid work at considerable } \\
\text { depths in materials prevailingly soft, } \\
\text { but having occasional hard layers. }\end{array}$ \\
\hline
\end{tabular}

TYPES OF CURBS AND CASINGS.

Just as there are various types of wells, so are there various methods of curbing and casing (or lining) the well, each method being likewise particularly adapted to a special type of well or to a certain definite kind of material. In some types of wells-for example, in dug, bored, and punched wells-several kinds of curbing or casing may be used, and the selection should be governed by the sanitary protection or resistance to the entrance of pollution which the casing affords. On no other single thing does the safety of the well depend to so great an extent as on the nature of the curbing or casing employed. The more common types of curbings and casings, their advantages and disadvantages, and the conditions to which they are best adapted are shown in the following tables:

Types of well curbs and casings.

\begin{tabular}{|c|c|c|}
\hline Type. & Nature. & Conditions to which best adapted. \\
\hline Rock.. & $\begin{array}{l}\text { Broken or dressed rock laid without } \\
\text { cement, usually in circle } 3 \text { to } 6 \text { feet in } \\
\text { diameter. }\end{array}$ & $\begin{array}{l}\text { Adapted to shallow dug wells, in mate- } \\
\text { rials carrying water mainly as small } \\
\text { seeps, where there is no near-by } \\
\text { source of pollution. }\end{array}$ \\
\hline Brick... & $\begin{array}{l}\text { Porous brick laid without cement, } \\
\text { usually in circles } 3 \text { to } 6 \text { feet in diame- } \\
\text { ter. }\end{array}$ & Same as rock curbs. \\
\hline $\begin{array}{l}\text { Cement-lined rock or } \\
\text { brick. }\end{array}$ & $\begin{array}{l}\text { Brick or stone as above, but laid in and } \\
\text { lined with cement. }\end{array}$ & $\begin{array}{l}\text { Adapted to shallow-dug wells in mate- } \\
\text { rials carrying enough water to permit } \\
\text { an adequate supply to enter at the } \\
\text { bottom. Can be used in polluted } \\
\text { soils if the contamination is super- } \\
\text { ficial and does not reach to the bot- } \\
\text { tom. }\end{array}$ \\
\hline
\end{tabular}


Types of well curbs and casings-Continued.

\begin{tabular}{|c|c|c|}
\hline Tppe. & Nature. & Conditions to which best adapted. \\
\hline Wood... & $\begin{array}{l}\text { Square wooden boxes in wells over } 3 \\
\text { feet in diameter; cylindrical curbs } \\
\text { of narrow staves in wells under } 3 \text { feet } \\
\text { in diameter. }\end{array}$ & $\begin{array}{l}\text { Can be placed in any shallow well, but } \\
\text { are never safe and should never be } \\
\text { used. }\end{array}$ \\
\hline Tiles. & $\begin{array}{l}\text { Glazed sewer tile, cement tiles, and } \\
\text { porous terra cotta tiles, laid without } \\
\text { cement. }\end{array}$ & $\begin{array}{l}\text { Adapted to conditions similar to those } \\
\text { of rock and brick curb. }\end{array}$ \\
\hline Do. & $\begin{array}{l}\text { Glazed sewer tile and cement tile with } \\
\text { cemented joints. }\end{array}$ & $\begin{array}{l}\text { Same as cement-lined stone or brick } \\
\text { curbs, except that it is more appli- } \\
\text { cable to wells of small diameter. }\end{array}$ \\
\hline Heavy iron casings. . & $\begin{array}{l}\text { Iron pipes, } 1 \text { to } 4 \text { inches in diameter, } \\
\text { with tight joints. }\end{array}$ & $\begin{array}{l}\text { Adapted to wells of all depths in which } \\
\text { water is obtained from a stratum be- } \\
\text { low the casing, or from strata be- } \\
\text { tween cased sections. Not adapted } \\
\text { to strongly corrosive waters. }\end{array}$ \\
\hline Sheet-iron casings.. & $\begin{array}{l}\text { Iron pipes } 4 \text { to } 16 \text { inches in diameter, } \\
\text { with snug joints. }\end{array}$ & $\begin{array}{l}\text { Adapted to wells of all depths, in loose } \\
\text { material, in which it is desired to pro- } \\
\text { cure water from a number of strata. }\end{array}$ \\
\hline
\end{tabular}

Summary of advantages and disadvantages of different types of well curbs and casings.

\begin{tabular}{|c|c|c|}
\hline Type of curbing. & Advantages. & Disadvantages. \\
\hline Rock. & $\begin{array}{l}\text { Allows all water to enter, thus utiliz- } \\
\text { ing all seeps. } \\
\text { Material often costs little or nothing. } \\
\text { As a rule requires little money outlay } \\
\text { for labor. }\end{array}$ & $\begin{array}{l}\text { Polluting matter enters readily and } \\
\text { well is never safe if near sources of } \\
\text { contamination. } \\
\text { Affords no filtration and permits dirt } \\
\text { and soil to enter. } \\
\text { Permits entrance of mice and other } \\
\text { small animals at top. }\end{array}$ \\
\hline Brick. . & $\begin{array}{l}\text { Where uncemented it allows all water } \\
\text { to enter, utilizing all seeps. } \\
\text { Filters out most of sediment. } \\
\text { Does not allow small animals to enter. } \\
\text { Involves little money outlay for labor. }\end{array}$ & $\begin{array}{l}\text { Polluting matter enters readily, and } \\
\text { well is never safe when near sources } \\
\text { of contamination. } \\
\text { Material costs considerable. }\end{array}$ \\
\hline $\begin{array}{l}\text { Cement-lined rock or } \\
\text { brick. }\end{array}$ & $\begin{array}{l}\text { Safe from pollution (except that enter- } \\
\text { ing at bottom) as long as walls are } \\
\text { not cracked. } \\
\text { Prevents entrance of sediments. } \\
\text { Prevents entrance of animals. } \\
\text { Does not impart taste to water. }\end{array}$ & $\begin{array}{l}\text { Utilizes water from bot om only. } \\
\text { Is unsafe if so shallow that polluting } \\
\text { matter can reach its bottom. } \\
\text { Costs considerably more than unce- } \\
\text { mented wells. } \\
\text { May require skilled labor. }\end{array}$ \\
\hline Wood.... & $\begin{array}{l}\text { Cheap in many localities. } \\
\text { Can be used in wells of very small di- } \\
\text { ameter. } \\
\text { Does not taste of iron. }\end{array}$ & $\begin{array}{l}\text { Swells tight in wet ground, the water } \\
\text { either entering at bottom or (after } \\
\text { sudden rises) through shrunk portion } \\
\text { at top. } \\
\text { Pollution enters readily. } \\
\text { Animals gnaw through. } \\
\text { Wood rots, giving taste to water and } \\
\text { favoring development of bacteria. } \\
\text { Expensive in some localities. }\end{array}$ \\
\hline $\begin{array}{l}\text { Glazed and cemented } \\
\text { tiles with uncemented } \\
\text { joints. }\end{array}$ & $\begin{array}{l}\text { Allows all water to enter, utilizing all } \\
\text { seeps. } \\
\text { Does not give taste to water. } \\
\text { Does not require skilled labor. }\end{array}$ & $\begin{array}{l}\text { Polluting matter enters readily and well } \\
\text { is never safe if near source of contami- } \\
\text { nation. } \\
\text { Soil may wash in through joints. } \\
\text { Requires some outlay for material. }\end{array}$ \\
\hline $\begin{array}{l}\text { Glazed and cement tiles } \\
\text { with cemented joints. }\end{array}$ & $\begin{array}{l}\text { Safe from pollution (except that enter- } \\
\text { ing at bottom) as long as joints are } \\
\text { tight. } \\
\text { Does not require expensive labor. }\end{array}$ & $\begin{array}{l}\text { Can be used only in soft materials con- } \\
\text { taining considerable water. }\end{array}$ \\
\hline Iron casings, & $\begin{array}{l}\text { Adapted both to rock and to uncon- } \\
\text { solidated materials. } \\
\text { Safe from pollution except that enter- } \\
\text { ing at bottom. }\end{array}$ & $\begin{array}{l}\text { The cost in large deep wells is consider- } \\
\text { ble. } \\
\text { Practically limited to wells under } 14 \\
\text { inches in diameter. } \\
\text { Is subject to deterioration by corrosion } \\
\text { and incrustation in some places. } \\
\text { Utilizes but one water stratum (except } \\
\text { where perforated). }\end{array}$ \\
\hline
\end{tabular}




\section{FACTORS GOVERNING SELECTION OF TYPE OF WELL.}

The type of well is the first and perhaps the most important point to be decided. Of the many kinds in use, including the dug, bored, and driven types and wells sunk by the jet process or drilled by rotary or percussion rigs, each possesses, on the one hand, one or more points especially qualifying it for use under one or more of the many varying conditions encountered in drilling, and on the other hand, some disadvantage which may disqualify it for use under certain other conditions. The chief factors which govern the selection of type are, usually, the amount of water needed, the character of the mat rials to be penetrated, the depth to which the well must be sunk, the cost of sinking the well, and the safety of the resulting supply. These factors are considered in detail in the following paragraphs.

YIELD OF WELLS OF VARIOUS TYPES.

If an adequate supply of ground water is available, the yield of a well will depend on the character of the water-bearing material, the facility of entrance of water, the size or storage capacity of the well, and the nature of the pumps.

Character of the material.-The character of the water-bearing material is of the greatest importance in determining the yield of a well, as it is on the structure and texture of the water-bearing beds, that the amount of water which they will give up depends. A close-textured clay, for instance, may hold as high as 45 per cent and a chalk as high as 53 per cent of its volume, while an open-textured sand may hold as little as 26 per cent of its volume. Notwithstanding this a sand will ordinarily yield large supplies, whereas a chalk and especially a clay will yield little or no water. In quicksands water is usually present in large amounts, but owing to the absence of good foundations for the curbing and the ready flow of the fine sand through the minutest crevices, ordinary dug wells in such material are generally out of the question and even driven wells equipped with the ordinary strainers usually soon become clogged. Driven or drilled wells equipped with special screens and sunk by experts familiar with the various methods of handling quicksand are usually the only types entirely successful in such material.

Structures, such as solution passages, bedding planes, or joints, play an important part in determining the yield of a well. A solution passage in limestone may afford inexhaustible supplies where the mass of the rock is practically destitute of water. In other rocks the bedding planes and joints may afford excellent supplies where no water is found in the rock itself. The amount of water present in the pores of different rocks is indicated by the following average porosities: Sandstones 15 per cent, shales 4 per cent, limestones 5 per cent, crys- 
talline rocks 2 per cent. The water present in the larger openings mentioned, though small in amount in comparison to that held in the pores, is yielded much more rapidly and, except in sandstones and similar porous rocks, usually affords the principal source of supply.

Facility of entrance.-The facility with which water enters the well depends in part on the rock features enumerated and in part on the nature of the well. In loose materials water accumulates most easily in stone-curbed and similar types of dug wells and only less so in tightly curbed dug wells with open bottoms. Where the water bed is a strong one and the materials are sufficiently consolidated to prevent them from entering the well the water will freely enter an iron casing open at the bottom. In weak water beds in soft materials, and in quicksands, either perforated casings or casings equipped with long screens are necessary to permit the entrance of the required amount of water. In many of the harder rocks the walls will stand without caving and casings are therefore unneccessary, the water entering at any point without hindrance.

Storage capacity of wells.-Where strong water beds exist storage is unnecessary, the water entering from the rock as fast as the pumps demand. Where the supply is derived from weaker beds, especially those having only small seeps, storage is a significant factor and the type and size of the well are of great importance. The volume of tubular wells of equal depth varies with the square of their diameters, hence a 6 -inch well will hold nine times as much water as a 2 -inch well of the same depth, and a 3 -foot well thirty-six times as much as a 6-inch well. Dug wells are therefore of advantage in clays and similar materials where the water enters more slowly than it can be lifted by the pumps, for they permit accumulations that may tide over periods in which the amount used is greater than the supply. For the deeper rock waters dug wells are impracticable and small-bore drilled wells must be used even where the supplies are slight. To get the best results the wells are generally made as large as can be afforded and sunk considerably below the point of entrance of the water, to afford the necessary storage.

DEPTH OF THE WATER.

The depth of the water is a factor of importance in the determination of the type of well to be sunk. A dug well, for instance, is suitable only when the water is within 30 or 40 feet of the surface, although many deeper dug wells exist. A punched well is commonly limited to depths of 50 feet, and a bored well is with difficulty carried to depths greater then 100 feet. Driven wells are most suitable at depths of less than 150 feet, although they are sometimes successfully extended to depths of 250 to 300 feet, or even to 400 or 500 feet or $46449^{\circ}$-w s P $255-10-3$ 
more, where the conditions are favorable. Jet wells are usually sunk only where it is not necessary to go much more than 100 feet from the surface. Wells of the California type are frequently extended to depths of 1,000, and occasionally to depths of 2,000 feet. Hydraulic rotary wells are successful to depths of 1,000 or 2,000 feet in the proper rocks. The percussion or churn drill may be used for all depths down to 5,000 feet, or deeper if special outfits are provided. Diamond drills have been successfully used to depths of 6,000 feet.

RELATIVE COST OF WELLS OF DIFFERENT TYPES.

So many items, such as accessibility to fuel, cost of labor, trade combinations, knowledge of water conditions, relative availability of different drilling outfits, and local practice, enter into the cost of a well that few definite statements can be made. Instances are not uncommon where wells of certain types have been put down for onetenth the price demanded for wells of the same type in other regions where conditions are essentially similar. In general, however, if only actual outlay of money is considered the dug well is the cheapest, for it may be constructed by the owner himself at times when he has nothing else to do. Bored and driven wells do not require expensive rigs and are often cheaper than dug wells when paid labor is employed in their construction. California wells for deep bores in soft materials are moderately cheap where the proper outfits are available, but unfortunately their use is as yet confined mainly to a single region. The jet process is adapted to the sinking of a large number of adjacent wells in soft materials, especially sand, and is occasionally successful for single wells, although in most places driven wells can be put down at less cost. The hydraulic and rotary processes may be cheaper than straight drilling where there are numerous alternations of hard and soft material. Of the processes in use for drilling in rock the standard rig (percussion drill) is the cheapest, the calyx and diamond systems being generally used only when cores of the rocks penetrated are desired. A more detailed comparison of the methods is given in the subjoined table. Although the relative costs indicated are fairly constant over the country as a whole, the cost of any method in a particular locality may be entirely abnormal, owing to the lack of drilling outfits capable of doing the work or to the existence of peculiar conditions rendering its operation difficult. 
Cost of wells.

[By O. E. Meinzer.]

\begin{tabular}{|c|c|c|c|c|}
\hline Formation. & $\begin{array}{l}\text { Diameter in } \\
\text { inches. }\end{array}$ & Locality. & Explanations. & Cost per foot. \\
\hline Limestone......... & $6 \ldots \ldots$ & $\begin{array}{l}\text { Illinois, Iowa, } \\
\text { Minn e s o t a, } \\
\text { Wisconsin. }\end{array}$ & No casing required.......... & 50 cents to $\$ 1$ \\
\hline $\begin{array}{l}\text { Glacial drift and } \\
\text { Cretaceous shale. } \\
\text { Do............ }\end{array}$ & $\begin{array}{l}2 \ldots \ldots \ldots \\
4 \ldots \ldots \ldots \ldots\end{array}$ & $\begin{array}{l}\text { Iowa and Minne- } \\
\text { sota. } \\
\text {. . . do.......... }\end{array}$ & $\begin{array}{l}\text { Heavy iron casing furnished; } \\
\text { water guaranteed. } \\
\text {. do. }\end{array}$ & $\begin{array}{l}55 \text { cents to } \$ 0.75+. \\
\$ 1 \pm .\end{array}$ \\
\hline Glacial drift......... & 4 to 6 & Illinois............. & Light casing furnished.... & 50 cents or more. \\
\hline Do............. & Bored, 6 to 36. & $\begin{array}{l}\text { Minnesota and } \\
\text { Iowa. }\end{array}$ & $\begin{array}{l}\text { Casing not furnished; planks } \\
\text { or tiles are used. These } \\
\text { are expensive per foot, but } \\
\text { the wells are not as deep as } \\
\text { the drilled wells. }\end{array}$ & $\begin{array}{l}50 \text { cents to } \$ 1+\text {, in- } \\
\text { creasing wit h } \\
\text { depth. }\end{array}$ \\
\hline $\begin{array}{l}\text { G l a c i a } 1 \text { d r i f t } \\
\text { and Cretaceous } \\
\text { shale (mostly soft } \\
\text { shale). }\end{array}$ & $1_{4}^{1}$ at bottom... & $\begin{array}{l}\text { South Dakota } \\
\text { artesian basin. }\end{array}$ & $\begin{array}{l}\text { Casing furnished; flow of } \\
\text { clear water guaranteed. }\end{array}$ & $\begin{array}{l}\$ 350 \text { to } \$ 500 \text { for a } \\
\text { well } 900 \text { to } 1,000 \\
\text { feet deep. }\end{array}$ \\
\hline $\begin{array}{c}\text { Clay, free from } \\
\text { bowlders. }\end{array}$ & & Utah...... & Casing not furnished....... & 20 cents. \\
\hline Clay, sand, and & Dug, 3 to 4 feet. & .... do .... & Not cased . . . . . . . . . . . . & $\$ 1.50$ to $\$ 2$, increas- \\
\hline Quartzite.......... & 6. & Minnesota... & $\begin{array}{l}\text { No casing required; yield of } \\
3 \text { barrels an hour guaran- } \\
\text { teed. }\end{array}$ & $\$ 3$ to $\$ 4$ \\
\hline Alluvium..... & 4 to $12 \ldots \ldots$. & California...... & $\begin{array}{l}\text { Casing not furnished. Stove- } \\
\text { pipe casing costs from } 32 \\
\text { cents a foot for } 4 \text {-inch } 16- \\
\text { gage pipe to } \$ 1.40 \text { a foot for } \\
\text { 12-inch 10-gage pipe. }\end{array}$ & $\begin{array}{l}30 \text { to } 65 \text { cents a foot } \\
\text { for } 4 \text { to } 10 \text { inch } \\
\text { wells, for first } 100 \\
\text { feet, with addi- } \\
\text { tional charge of } \\
25 \text { to } 35 \text { cents a } \\
\text { foot for each ad- } \\
\text { ditional } 50 \text { feet in } \\
\text { depth. }\end{array}$ \\
\hline
\end{tabular}

SAFETY OF WELLS.

The safety of a well depends on the purity of the water at its source and on its protection against the entrance of contaminated waters and polluting solids. The type of well does not affect the purity of the original source; but if the water supply is primarily pure, its maintenance in that condition depends largely on construction that prevents contamination.

Polluting matter finds entrance to wells in a variety of ways. In dug wells it enters through the crevices in the stone, brick, or wood curbing, or possibly through the brick itself; in bored wells it enters through the uncemented joints of the tiling or through cracks between the staves of tubular wooden curbing; and in drilled and driven wells through leaky joints or holes eaten in the iron casing by corrosive waters. By cementing the interior surfaces of stone or brick curbed wells, by replacing wood by cement or other impervious curbs, and by substituting new pipes for leaky iron casings the entrance of polluting matter through the walls can be prevented. Little or nothing enters the small tubular wells from the top and they may, therefore, be regarded as free from danger of pollution from this point. The larger open wells should be protected by a water-tight iron or cement cover standing somewhat above the level of the surrounding ground and tightly joined to the curb proper. The sloping of the earth away from the well serves to turn rainwater or pump 
drippings away from it, so that little will penetrate, even if the curb becomes cracked by frost.

A particularly dangerous type of well-the more so because of the fancied security of the owners-is the combination dug and drilled type. Because of a slight saving of expense, drilled wells are frequently sunk in old dug wells, the casing commonly beginning at the bottom of the old well. Although the water encountered by the deep well may be perfectly pure, it is liable to be contaminated, especially after rains, by the entrance of seepage waters into the open well and thence into the drilled well. The remedies are obvious; either the casing should be carried to the surface of the outside ground, or at least above the highest level ever reached by the water, or the open well should be converted into a water-tight cistern by the application of a thick coat of cement over both sides and bottom.

SUMMARY.

The factors determining the desirability of wells of different types are concisely summarized in the following table, in which the first column shows the chief advantages of each type, while the second column shows the offsetting disadvantages.

Summary of advantages and disadvantages of different types of wells.

Dug wells.

\begin{tabular}{l|l}
\hline \multicolumn{1}{c|}{ Advantages. } & \multicolumn{1}{c}{ Disadvantages. } \\
\hline $\begin{array}{l}\text { Ease of construction; can be located, sunk, } \\
\text { and cased by owner. } \\
\text { Only hand power required. }\end{array}$ & $\begin{array}{l}\text { Limitation to soft materials; liability to caving while } \\
\text { being dug. }\end{array}$ \\
$\begin{array}{l}\text { No oxpensive materials required for curbing. } \\
\text { Cheapness in soft material. }\end{array}$ & $\begin{array}{l}\text { Costliness in hard rock. } \\
\text { Wood curbing often used affords favorable conditions for } \\
\text { the development of bacteria. } \\
\text { Slight depth to which it can be sunk. } \\
\text { Ease of entrance of polluting matter through and over } \\
\text { top of curb. } \\
\text { Water, not being replenished, is often stagnant. } \\
\text { Fails frequently in time of drought. } \\
\text { Must usually be at distance from house and from barns, } \\
\text { privies, and cesspools to insure safety. } \\
\text { Necessity for frequent cleaning; danger from gas while } \\
\text { cleaning. } \\
\text { Short life when curbed with wood. } \\
\text { Ease of entrance of animals and refuse through open top. }\end{array}$ \\
$\begin{array}{l}\text { Utilization of all water strata. } \\
\text { Qtilization of small seeps. }\end{array}$ \\
Large storage capacity. \\
Accessibility for cleaning.
\end{tabular}

Bored wells (Iowa type, 1 to 3 feet in diameter, pervious curbing).

\begin{tabular}{l|l}
\hline $\begin{array}{l}\text { Ease of construction; only hand or horse } \\
\text { power required. }\end{array}$ & $\begin{array}{l}\text { Slowness of method as compared with driving. } \\
\text { No expensive materials required for curbing. } \\
\text { Cheapness. } \\
\text { Utilization of all water strata where curbed } \\
\text { with uncemented tile. } \\
\text { Utilization of small seeps. }\end{array}$ \\
$\begin{array}{l}\text { Suick response to rainfall outfit required for all but small shallow holes. } \\
\text { Limited to soft materials. } \\
\text { Ease of entrance of polluting matter through curb and } \\
\text { over top. } \\
\text { Limitation of points of entrance of water to top and bot- } \\
\text { tom with many wooden curbs. } \\
\text { Wood curbs favor development of bacteria. } \\
\text { Water, not being replenished, is often stagnant in larger } \\
\text { bores. fonsiderable storage capacity. } \\
\text { Failures frequent in droughts. } \\
\text { Accessibility of larger types for cleaning. } \\
\text { safety. of location at distance from house to insure } \\
\text { Necessity of frequent cleaning; danger from gas while } \\
\text { cleaning in the larger types. } \\
\text { Limitation of practicable depth of large bores. } \\
\text { Limitation of size. } \\
\text { Short life when curbed with wood. }\end{array}$ \\
\hline
\end{tabular}


Summary of advantages and disadvantages of different types of wells-Continued.

Bored wells (Arkansas type, 2 to 12 inches in diameter, tight casings).

\begin{tabular}{|c|c|}
\hline Advantages. & Disadvantages. \\
\hline $\begin{array}{l}\text { Ease of construction; only hand or horse } \\
\text { power usually required; skilled labor not es- } \\
\text { sential in shallower holes. } \\
\text { Cheapness for moderate depth. } \\
\text { Deeper wells little affected by drought. } \\
\text { Pollution shut out if properly cased. } \\
\text { Gives good records of materials penetrated and } \\
\text { water beds encountered. }\end{array}$ & $\begin{array}{l}\text { Limitation to soft materials. } \\
\text { Not adapted to very deep wells. } \\
\text { Utilizes only one stratum in most places. } \\
\text { Other disadvantages similar to those of drilled wells. }\end{array}$ \\
\hline
\end{tabular}

\section{Punched wells.}

When provided with pervious curbings the advantages are similar to those of open and Iowa type bored wells; when provided with tight casings the advantages are similar to those of the Arkansas type bored wells.
Similar to those of open wells and the larger type of bored wells.

Difficulty of operation; liability of crooked holes.

Usual limitation to depths under 50 feet.

Limitation to soft yet stiff materials, which are generally of local distribution.

\section{Driven wells.}

Ease of construction; often sunk in a few hours; only hand or horse power usually required.

Outfit is inexpensive, can be quickly put up, and does not require skilled labor.

Tubing is readily obtainable and inexpensive. Cheapness.

Safety; can be located near sources of pollution if sunk through impervious bed preventing access of contaminating matter to water bed; nothing can enter at top.

Permanency of supply as compared with dug wells.

Cleaning seldom necessary as compared to open wells.

\section{Limitation to soft materials.}

Utilization of a single water stratum.

Usual limitation to moderate depths.

Restriction to open porous water beds due to absence of storage facilities.

Slow response to rainfall as compared to many dug wells. Corrosion of pipes or well points.

Incrustation of pipes and well points.

Entrance of quicksand through well points.

Taste of water due to solution of the iron under certain conditions.

Difficulty of cleaning in case of clogging.

Short life as compared to some dug wells.

Absence of information as to minor water beds or materials penetrated.

\section{Stovepipe or California wells.}

Utilization of all horizons of water.

Cheapness of casings as compared with largesized driven or drilled wells.

shortness of sections, permitting use of steady pressure by hydraulic jacks.

Adaptability to conditions where driving is impossible.

Flush outer casings and absence of screw joints.

Ready adjustment to strains.

Avoidance of clogging of perforations.

Exclusion of sources of pollution.

Affords fair records of materials and water beds encountered.
Limitation to soft materials

Lack of strength of casing; distortion by lateral pressure; pulled with difficulty if distorted.

Thinness of casing and shortness of life where waters are corrosive.

Expensive; requires elaborate outfit available in only a few sections of country, skilled labor, etc. Cleaned with difficulty.

Slight storage capacity.

Taste of water due to solution of iron by corrosive waters. Short life under some conditions. 
Summary of advantages and disadvantages of different types of wells-Continued.

Standard drilled wells.

\begin{tabular}{|c|c|}
\hline Advantages. & Disadvantages. \\
\hline Adapted to all rocks. & $\begin{array}{l}\text { Expensive; requires elaborate outfit, skilled labor, steam } \\
\text { power with the attendant charges, and costly casing } \\
\text { and pumps in deeper wells. }\end{array}$ \\
\hline $\begin{array}{l}\text { No ordinary limitation as to depth. } \\
\text { Can be readily deepened. } \\
\text { Little affected by droughts. }\end{array}$ & $\begin{array}{l}\text { Many difficulties in drilling; frequent losses of tools. } \\
\text { Cleaned with difficulty. }\end{array}$ \\
\hline $\begin{array}{l}\text { Can utilize all water strata where there is no } \\
\text { great difference in head if casing is perforated, } \\
\text { but this is rarely done. }\end{array}$ & Slow response to rainfall; slight storage capacity. \\
\hline $\begin{array}{l}\text { Pollution is completely shut out if properly } \\
\text { cased. }\end{array}$ & \\
\hline Can be located anywhere. & Incrustation of pipes and screens. \\
\hline $\begin{array}{l}\text { Gives fair records of materials and water beds } \\
\text { encountered. }\end{array}$ & $\begin{array}{l}\text { Entrance of sand through screens or clogging of screens. } \\
\text { Taste of water due to solution of iron under certain con- } \\
\text { ditions. }\end{array}$ \\
\hline
\end{tabular}

\section{Diamond-drill holes.}

Gives complete core of rocks penetrated. Can be drilled at any angle.

Other advantages similar to those of other drilled wells.
Adapted only to hard rocks.

Requires costly outfit and materials, skilled labor, steam power, ete.

cost greater than drilled wells.

Other disadvantages similar to those of drilled wells.

Wells sunk by calyz and steel-shot method.

Outfit and cost of sinking less than in diamond-drill holes.

Readily used in connection with hydraulicrotary rig when hard rocks are encountered.

Other advantages similar to those of drilled wells.
wer adv
Both outfit and cost of operation more than in drilled wells.

Only vertical 1 wells can be drilled.

Slower than diamond drilling.

Other disadvantages similar to those of drilled wells.

\section{Wells sunk by jet process.}

Rapid in soft materials; operates con tinuously. Cheap compared with hydraulic, hydraulic rotary, and drilling methods.

Supplies inexpensive and readily obtainable.

Adapted to incoherent materials, such as sand, not capable of standing alone.

Affords fair records and samples of materials penetrated.

other advantages similar to those of driven wells.
Limited to soft materials.

Requires more apparatus than driven wells; requires skilled labor.

Requires previous supply of water.

Small water seams not readily recognized.

Draws from single water bed.

Requires strong water beds due to absence of storage facilities; seeps can not be utilized.

No storage capacity.

Usually limited to small diameters.

Satisfactory only in wells of moderate depth.

Slow response to rainfall as compared to shallow-dug wells.

Corrosion and incrustation of pipes.

Taste of water due to solution of iron by corrosive waters. Difficulty of cleaning.

Wells sunk by hydraulic process.

Rapid in soft materials.

Can be used where soft and hard beds alternate, but works best in uniform materials. Penetrates hard beds by fall of drill.

Operation nearly continuous.

Affords good records.

Other advantages similar to those of drilled wells.
Usually limited to relatively small diameters.

Requires previous supply of water for drilling process.

Other disadvantages similar to those of drilled wells. 
Summary of advantages and disadvantages of different types of wells-Continued.

Wells sunk by hydraulic rotary process.

\begin{tabular}{|c|c|}
\hline Advantages. & Disadvantages. \\
\hline Very rapid in soft materials. & $\begin{array}{l}\text { Satisfactory only where the materials are prevailingly } \\
\text { soft }\end{array}$ \\
\hline $\begin{array}{l}\text { Applicable to alternations of soft and hard } \\
\text { material. } \\
\text { operations are relatively continuous; little } \\
\text { lost time. }\end{array}$ & $\begin{array}{l}\text { Small water seams not readily recognized; shut off by } \\
\text { puddling by thick sludge. } \\
\text { Requires previous supply of water for process of sinking } \\
\text { well. }\end{array}$ \\
\hline $\begin{array}{l}\text { Can penetrate hard beds by use of calyx appli- } \\
\text { ance and chilled-steel shot. }\end{array}$ & $\begin{array}{l}\text { Affords unsatisfactory records. } \\
\text { Possible for polluting matter to penetrate by passage } \\
\text { through loosened zone and casing. }\end{array}$ \\
\hline $\begin{array}{l}\text { Other advantages similar to those of drilled } \\
\text { wells. }\end{array}$ & Other disadvantages similar to those of drilled wells. \\
\hline
\end{tabular}

OPEN OR DUG WELLS.

LOCATION.

The chief considerations in the location of open wells and wells in which pervious casings are used, in the order of importance usually ascribed to them by the owners, are: Cost, accessibility, convenience, and safety. The requirements, unfortunately, of ten conflict. Most houses and barns are located on elevations for the sake of good drainage, sightliness, or other considerations, but wells in such situations are rarely as cheap as the less convenient wells in the hollows. Again, convenience often demands that the well be located near the house, where slops are thrown upon the ground, in the vicinity of a cesspool or privy, or near the barnyard or hogpen, while safety demands its location on high ground at a considerable distance from these and other sources of pollution.

In cases of conflicting requirements it is usually the cost which eventually determines the location, or rather it is the initial cost, for in many instances the final cost of a proper installation-if the cost of the resultant loss of health is considered-is much less than that of an improper installation although the latter may not produce actual disease.

A safe well is nearly always, in the long run, the cheapest, such a well being decidedly cheaper than the cost of medical attendance. Safety should invariably be made the first consideration instead of the last. A well should never be put down in a doubtful situation, even as a temporary makeshift, for the owner almost always waits until too late before replacing it.

\section{SOURCES OF POLLUTION.}

Open or dug wells may be polluted by material seeping through the ground and curbing or entering from the top of the well. Of the seepage materials cesspools and privies are the most important source. In most localities the large amount of liquid reaching such recep- 
tacles is rapidly absorbed by the earth and becomes a part of the water body feeding the wells. Slops thrown on the surface likewise soak into the ground, and even if the liquid at first evaporates the residue is later taken up by the rain which sinks into the ground, and is carried downward to the ground-water body. The matter leached from hen yards, from hogpens, and from the manure piles near barns, eventually enters the ground and finds its way in one form or another to the ground water below. Drainage from manured fields and from pastures occupied by stock may also be a prominent source of pollution. Much of the polluted water from such sources is purified by passage through the ground and the danger of pollution of well waters by seepage is commonly exaggerated, yet gross carelessness in locations of wells near privies, cesspools, drainpipes and other filth receptacles is prevalent in many farm districts.

One of the greatest sources of pollution for farm wells is the entrance of material at the top, and dug wells are especially liable to contamination of this sort, though other well types are not entirely exempt.

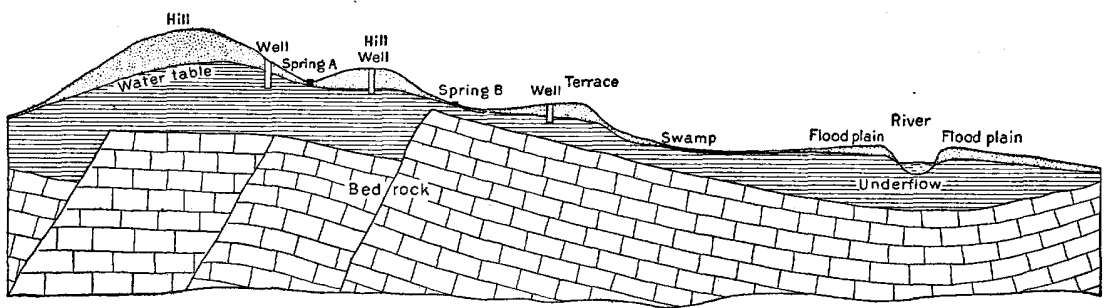

FIGURE 17,-Section showing relation of water table to surface irregularities.

Of the material entering a well from the open top dust is an important source of contamination. It is always present in the air and the amount actually settling is very many times more than the conspicuous dust coatings collecting in buildings. In fact, in open wells, especially in regions where brisk winds are common, the accumulations sometimes amount to several inches in a year. Many wells which are cleaned only once in two years are found to contain as much as 6 inches of foul-smelling black muck, representing the dust and other refuse entering the well in that length of time.

Small animals, such as toads, mice, moles, and snakes, fall into the well in times of drought when the sources of water they usually depend on have failed.

Except that it keeps the larger animals out and is a convenience in using the well, the ordinary plank covering affords but little improvement over the open well. Crevices almost invariably exist through which the smaller animals may find access, and the dirt washed through the cracks by the pump drippings may be almost equal to that entering through an open top. Moreover, it is a very 
dangerous type of dirt, as in many places it includes filth from domestic fowls and from the shoes of farm hands and others coming from manured fields, hogpens, or barnyards.

\section{MOVEMENT OF GROUND WATER.}

When a well is carried downward in porous or semiporous materials, such as those in which most open wells are located, a level is soon reached, below which the ground is saturated with water (at least down to the first impervious stratum). This water body, or ground water, as it is called, has a definite upper surface, known as the water table, which conforms in general with the broader surface irregularities as shown in figure 17, but with the difference that the

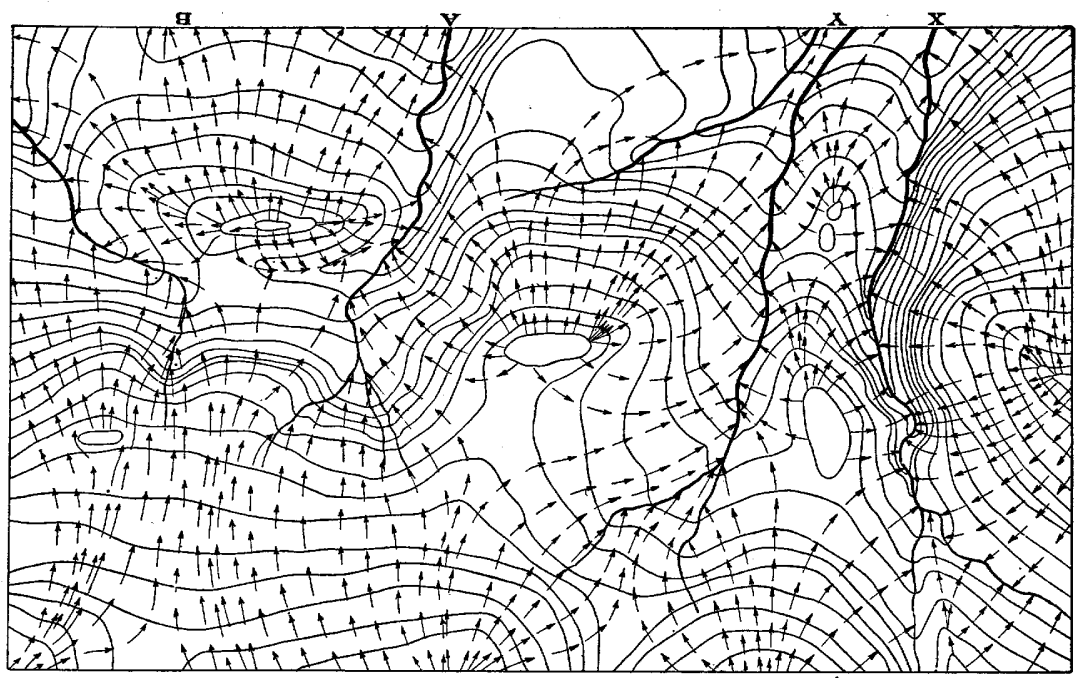

FIGURE 18.-Map showing position of water table by contours (continuous lines), lines of motion of ground water (arrows), and surface streams.

section of the water table is flatter than that of the surface, being far below the ground on hilltops and cutting the surface in valleys. The motion of the ground water is in the direction of steepest slope of the water table, as illustrated in figure 18, and as this roughly coincides with the surface slope it follows that the direction of motion of the ground water generally approximates that of the surface drainage.

From the laws of occurrence thus outlined it appears that low points are the most favorable for obtaining water by open wells, as the water movements converge in that direction and the water table is nearer the surface there than elsewhere. Sewage, being to a large extent simply water to which a certain amount of foreign polluting matter has been added, follows the same laws of motion as the ground water, converging in an identical manner toward the low spots, which are therefore points of danger where sources of contamination occur on the adjacent slopes. 
By "safety distance" is meant the distance from a source of pollution at which a well may be sunk with a fair degree of safety. Some writers have spoken of a "cone of safety," by which is meant an inverted conical section of earth with its apex at the bottom of the well and its base a circle of some fixed radius on the surface. The radius taken by some is the depth of the well, by others twice the depth of the well, but such limits are usually fixed without taking into consideration the nature of ground-water movements or the character of the passages in which it moves. The distance of safety also depends to a considerable degree on the quantity and concentration of the pollution entering the ground water. Where coming from the surface the amount is commonly not large, but where entering at a considerable depth, as from cesspools sunk in limestone or in porous sands which also supply water to wells, it may reach the water stratum almost undiluted. It follows that no absolute radius can be laid down, each case demanding individual consideration. Certain generalizations, however, may be made as to conditions in materials of different types and under different topographic conditions, some of which are indicated below.

Clay and till.-In ordinary clay and in the pebbly or bowlder clay known as "till" the water circulates in part by general seepagethrough the mass, in part through relatively thin sandy layers, and in part along more or less open but irregular tubular passages. Seepage through the body of the clay or till is very slow and polluting matter is rarely carried for any great lateral distance; 100 feet from the nearest source of pollution may perhaps be regarded as a safe limit. The clay offers even more resistance to the passage of water directly downward, a 5-foot bed as a rule effectively shutting off polluting matter from the underlying water beds, unless such matter obtains access along the break made in sinking a well or other excavation. When the water follows sandy layers the movement, though much faster than in uniform clay, is nevertheless not very rapid, rarely exceeding a few feet per day, and pollution does not often extend much over 150 feet, 200 feet usually being a safe distance. In open passages movement is much more rapid, and may amount to several hundred feet a day in extreme cases. Under such conditions there is no purification and relatively little dilution, and if the passage discharges into a well dangerous contamination may result. In a thickly inhabited region a well depending for its supply on passages of this nature is never safe.

Sand.-A bed of sand is among the safer water beds. Being of an incoherent nature, the material rarely contains open passages, the water circulating in general by a slow movement among the grains. 
The rate, though sometimes amounting to 50 feet or more a day, is usually under 5 feet and may be under 1 foot. A well 200 feet from the nearest point of pollution is probably safe in fine and medium sands, but in coarse sands and gravel a much greater distance may be essential.

Sandstone.-The movement of water in sandstone is in part through the body of the rock and in part through small open passages along the joint or bedding planes. Owing to the greater density of the rock resulting from the cementation of the grains the distance to which pollution may extend through the pores of the rock is less than in sand, 100 feet usually being a safe distance. Probably even with the water moving along the joints and bedding planes 125 to 150 feet from the source of pollution is a safe distance for a well.

Slate and shale.-In slate and shale the water follows in part the planes of stratification or bedding and in part the more or less vertical joints by which these rocks are usually cut. Unless certain of the layers are sandy the movement along the bedding planes is generally slow and pollution is carried for only short distances. The joints, however, are in many places fairly open and may conduct the water within a short time to considerable distances, possibly many hundred feet, like the granite joints described on page 15. However, unless the examination of the rock or the behavior of the drill in the well shows the presence of such open joints, a well in slate or shale may usually be considered safe if not less than 100 feet from a source of pollution.

Limestone.-The movement of water through limestone is almost entirely by means of open passages. Some of these are only a minute fraction of an inch in width, being no wider than joint and bedding planes. In such passages the movement of water is very slow and pollution is rarely carried far, 150 feet from a possible source usually being a safe distance. Other passages, however, are of considerable size, perhaps many feet in diameter, and may extend for miles. One chamber in Mammoth Cave is nearly 10 miles long, and there is evidence that similar though perhaps smaller channels exist at numerous other points. These openings are not uncommonly occupied by flowing streams which, if polluting matter is introduced, may carry it for many miles. Such streams may have connection with surface sink holes. Cornstalks and other refuse from the surface not infrequently appear in wells drawing water from limestone, and the waters are often muddy after storms. Such occurrences are indications of surface contamination and the waters should be avoided if possible.

Granite.-Practically no water passes through the body of granite, the movement being mainly along joint or fault planes or through 
pore spaces in the disintegrated upper portions of weathered granite masses. Polluting matter may reach to considerable distances through joint or fault planes, as is indicated by the fact that the salt water of the ocean finds entrance to some wells located 500 feet, and in places even a quarter of a mile or more, from the shore. It is said that in the deep public well sunk in granite at Atlanta, Ga., sufficient polluting matter entered through a joint struck at 1,160 feet from the surface to render the water unfit for drinking.

\section{PROTECTION.}

Protection from surface wash.-Many open wells are exposed to the same danger of pollution from surface wash as springs, and the same methods of protection should be used. A water-tight curb should be raised a few inches or a foot above the level of the surrounding surface and the earth banked around it, with a slope away from the well. This curb quickly deflects the water and prevents it from collecting and soaking through the ground into the well.

Protection from stock.-The chief means in which wells become polluted by stock is through seepage from the surface. Watering troughs are commonly placed close to wells, and usually in such places the hoofs of the animals soon wear holes in which the rain water and more or less of the animal excrement collect and soak into the ground, finally reaching the well. To prevent this contamination the watering trough should be placed as far away from the well as possible, the water being conducted to it by pipes. A well in an open pasture, if it is to be used at all by human beings for drinking water, should be surrounded by a fence at least 20 feet away.

Protection from pump drippings.-The drip from pumps is a very common and dangerous source of pollution. In the greater proportion of dug wells provided with pumps the well is covered with boards or planks laid or nailed over the top. No matter how carefully these platforms are constructed cracks through which water can enter almost invariably exist, and it is a common occurrence to have the water dropping or trickling back into the well whenever any is spilled in pumping. The danger of this will be understood when it is recalled that those stepping upon the platform to pump may have just come from the barnyard or from manured fields, bringing with them on their shoes more or less filth, part of which is left on the planking and washed into the well by dripping water from the pump or by the next rain. The wooden platform should be replaced by a water-tight cover made of iron, cement, or other impervious material. Cement covers are coming into use in many localities and afford ideal protection.

Protection from small animals.-An ever-present cause of pollution in open wells and wells insufficiently protected by coverings is 
the entrance of small animals. It is a common thing for snakes, toads, mice, and even rabbits to penetrate through crevices and to fall into the well, especially in dry seasons when the animals are compelled to make desperate attempts to reach water. The remedy is an impervious well cover fitted tightly to the curb.

Protection from dust.-Dust is usually less dangerous than other sources of pollution, but in dry seasons, when dirt from the street or barnyard is being blown about, it may become of considerable amount and danger. It is not uncommon to find several inches of black, foulsmelling silt in the bottom of a well on cleaning, even s' have been cleaned only a year or two before. The dust may be kept out by water-tight coverings such as are used to keep out pump drippings.

\section{INCREASING THE YIELD.}

The methods of increasing the yield of wells vary according to whether the well is of the dug or drilled type and whether the existing supply has or has not materially decreased from the original supply. An originally inadequate yield commonly results from insufficient supplies in the water-bearing rock or from the slowness with which the supplies are given up. A decreased yield may be due to some defect in the well itself.

Remedy for insufficient supplies.-Ordinary clay and the denser varieties of pebbly and bowlder clay or till usually contain but little water, and this little is often largely in the form of interstitial water held in the body of the material and given up slowly to a well by general seepage. Under such conditions the amount entering the well is often more or less proportional to the area of surface exposed in the wall. This area varies with the diameter of the well; thus, three times as much surface will be exposed in a given height of wall in a 6-inch well as in a 2 -inch well and six times as much in a 3 -foot as in a 6-inch well. To give a large yield a large-diameter well is very desirable in materials of the character mentioned.

Large wells are also desirable in rocks in which the water occurs in a similar manner-that is, in pores rather than in open passages. In general, however, if water is yielded at all by the rocks, it is given up more readily than by clays, hence a large bore is less necessary This is fortunate, for the range of size in rock wells is usually rather scant, owing to the fact that most rock wells are of the drilled type. Where the water occurs in bedding or joint planes the diameter is of still less importance, as the entrance of the water is localized and is relatively free. Large diameters, nevertheless, increase materially the likelihood of striking an opening. In the oil regions the increase of the diameter of a bore 2 inches by reaming has been known to open pools not encountered in the original hole, and a similar result is possible in water wells. 
The depth of dug wells in material in which the amount of water is relatively small is also important, for increase in depth increases the storage space in which the water can collect during periods when the well is not in use, thereby greatly adding to its total capacity.

In many regions, owing to the removal of the forests and the construction of drainage ditches, the water from rainfall and snowfall runs off more rapidly than formerly and much less sinks into the ground. As a result the ground-water level has been lowered over large areas and wells which once afforded good supplies are now dry. In many places there is still plenty of water in the ground, the only difference being that its level has sunk below the bottom of the well. In such places the deepening of the well brings complete relief.

Cleaning the well.- In the course of time an accumulation of material entering the well as dust at the top, or washed in through the ground, forms considerable amounts of silt in the bottom and on the sides. In some wells this deposit is sufficient to hinder, to a certain extent, the entrance of water into the well and to lessen its storage capacity. Some relief is usually afforded by cleaning out the well.

\section{DEEP WELLS.}

Depth is one of the most important factors to be considered in sinking a well. On it both the type and the location often depend. The benefits which the owner expects to realize from a deep well as compared to a shallow well are (1) larger supply, (2) higher head, and (3) purer water.

\section{LOCATION.}

In the location of deep wells the chief consideration is the obtaining of a supply, slight differences in location seldom seriously affecting the cost, while the prevailing use of casing in soft deposits insures safety from ordinary sources of pollution. The occurrence of deep waters depends on the character and structure of the rocks far below the surface. No indications of these features are usually found at the surface, and the well may as a rule be located independently of surface relief, though where artesian flows are expected the well should be located on as low ground as possible. Information as to the best location for a deep well may often be obtained from a careful study of the records of wells in adjacent regions, which can be made by the more experienced and intelligent drillers, or from a study of the rocks and their structure, which often requires the services of a trained geologist.

GENERAL RELATIONS.

RELATION OF SUPPLY TO DEPTH.

It is a widespread, in fact an almost universal belief that the amount of water increases with depth and that water may be had anywhere if one only "goes deep enough." This is, however, far from the 
truth. Rainfall appears to be the source of at least 99 per cent of the fresh water found in the ground, the remainder being water included in the rocks at the time of their accumulation beneath the sea, together with a small amount derived from volcanic sources. As would be expected from its atmospheric source, water actually decreases rather than increases in amount with depth, a great many rocks encountered by the deeper wells and mines, especially at depths below 1,000 feet, being entirely destitute of water. ${ }^{a}$

However, if only the more superficial portion of the crust is considered, there is in general an increase of water with depth. Except in valley bottoms and other depressions the surface soil and rocks, although carrying much moisture, are rarely saturated; but at depths which vary, according to climate, soils, and topography, from a few to several hundred feet, a saturated zone constituting the groundwater body is encountered. Wells starting anywhere above drainage level will in general encounter water in increasing amounts at least down to the drainage level. Again, the surface beds may be of nonporous nature and may therefore be destitute of water, while the underlying beds, if porous and below drainage level, are likely to be saturated.

Of course there is a constant tendency for the surface waters to penetrate downward and fill the porous rocks below. That these are at present destitute of water may be due, at least in certain rugged regions, to the draining of the deeper and in places relatively porous beds by deep valleys. Elsewhere, and this is doubtless the most common cause, the water is kept from percolating downward by impervious beds near the surface. The deeper rocks are largely of the granitic type and hold but little water. Except where they constitute the surface rock and are somewhat broken by joints it is of little use to penetrate them in search of water.

To speak broadly, it may be said that there is no general increase of water with depth and that the finding of deep supplies is entirely dependent on local geologic conditions. Unless there is some proof that deep water-bearing beds exist, the sinking of a deep well should be regarded wholly in the light of an experiment, although in sedimentary rocks it has the decided advantage that it may penetrate a number of water strata, which may afford in the aggregate a fair supply where a single stratum might not suffice.

RELATION OF HEAD TO DEPTH.

As with regard to volume, there is a general belief that the head of water increases progressively with depth. This belief has a better basis than the other, for in some places such a relation of head to

$a$ Fuller, M. L., Total amount of free water in the earth's crust: Water-Supply Paper U. S. Geol. Survey No. 160, 1906, pp. 64-70. 
depth exists, as in the artesian system shown in figure 19, in which the deeper beds outcrop at successively higher levels.

The reverse condition is shown in figure 20. Such conditions are not the result of universally prevalent structures, although it is perhaps more common than otherwise that the strata are higher at the rims than they are at the centers of the great structural troughs. In many structural basins, the outcropping beds of the rims in fact lie high up on the flanks of mountains, while the beds of the center constitute low plains.

\section{RELATION OF QUALITY TO DEPTH.}

Another prevailing idea is that the deeper waters are purer. Within limitations this is generally true as regards the shallower waters, which, being close to the surface and without the protection afforded by overlying clays or other impervious beds, are susceptible to pollution. Deeper waters, on the other hand, are almost always overlain by relatively impervious beds that serve to keep out polluting

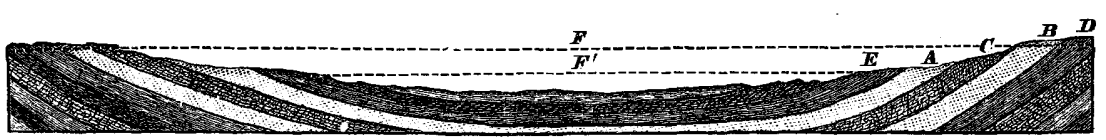

FIGURE 19.--Artesian system showing progressively higher outcrop of deeper beds.

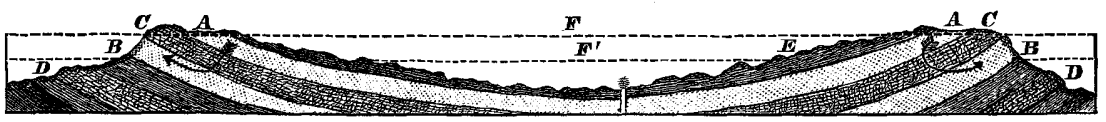

Figure 20.-Artesian system showing progressively lower outcrop of deeper beds.

materials, and as a rule they are entirely safe. In many places, however, the amount of mineral matter dissolved in the water shows a general increase with depth, the amount in deep waters averaging several times that in surface waters, which are largely made up of recent rainfall. There are some exceptions to this law, due mainly to variations in the character of the materials in which the waters are found, the waters in a calcareous glacial drift or in an alkaline flat, for instance, often being very much harder than those in underlying beds. Limestone waters, too, are generally harder than sandstone waters. The maxim of certain drillers, "The harder the rock the harder the water," is based on the prevailing softness of the sandstones in many districts as compared to the hardness of the limestones.

In addition to the impervious beds mentioned, the casing plays an important part in preventing the access of pollution to deep waters. When the casing has been corroded, pollution from sources near the surface is often admitted through the minute holes eaten in the iron, spoiling the deep waters. Where the casing does not entirely fill the 


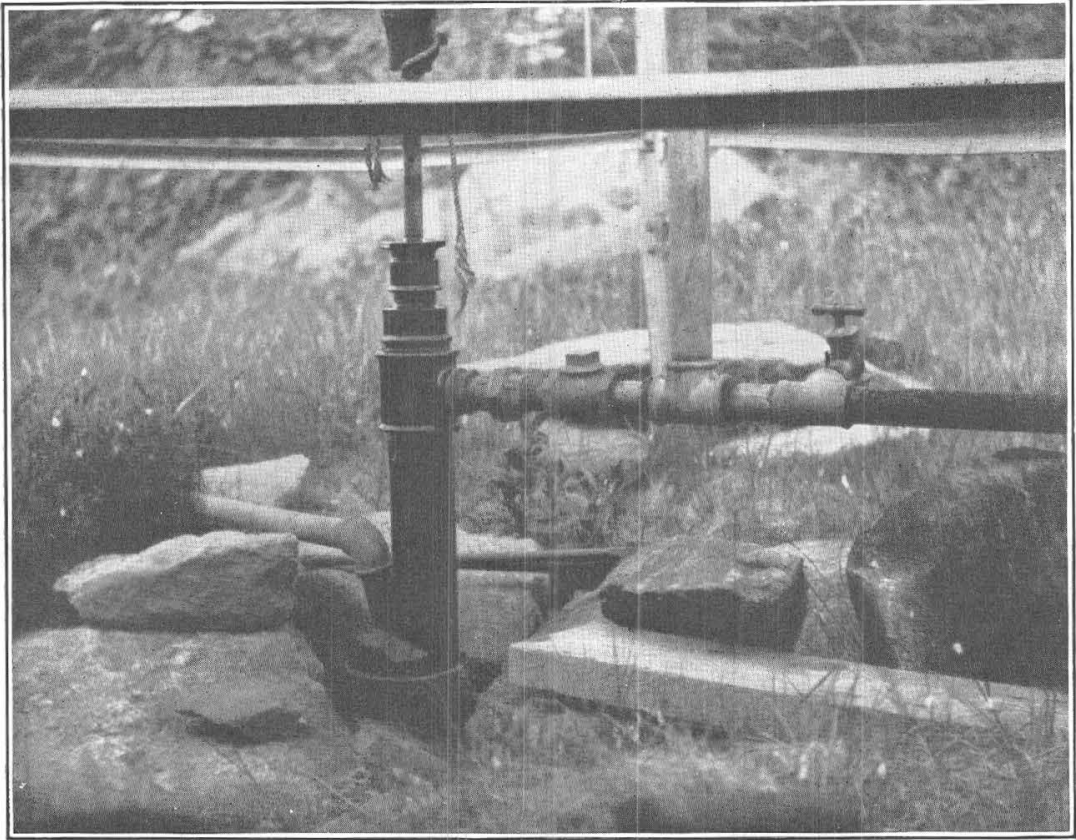

A. DRILLED WELL WITH OPENING BETWEEN OUTER CASING AND PUMP TUBE UNPROTECTED.

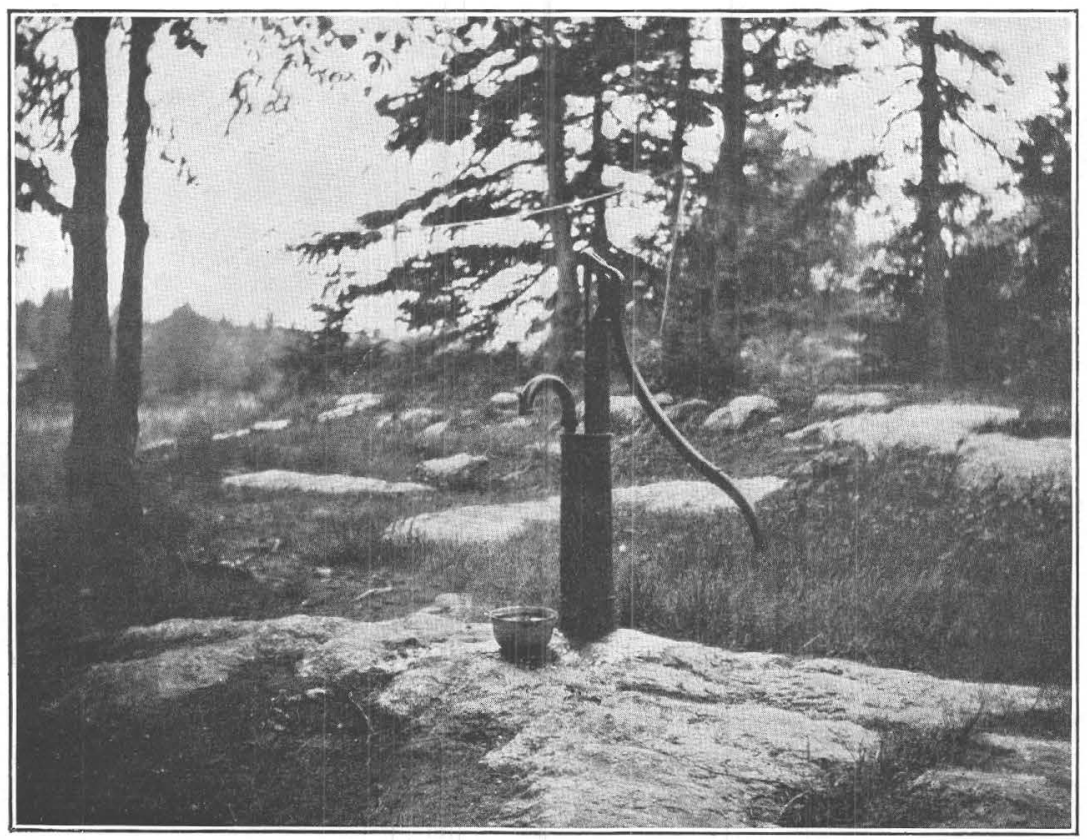

B. DRILLED WELL WITH OPENING AROUND CASING PROTECTED BY CEMENT. 
hole, contamination may pass down outside of it, while in uncased rock wells pollution may enter through any of the numerous fissures that usually exist in the upper part of the rocks. Even in such wells, however, the danger of contamination decreases rapidly with depth.

\section{SUMMARY OF CONCLUSIONS AS TO DEPTH.}

Contrary to the common belief, there is no general increase in the volume of underground water with increase in depth, such gain in volume as is occasionally found being due to peculiar local conditions: Neither is there a universal increase of head, although it may happen because the lower beds outcrop at higher altitudes than the upper ones (fig. 19). The deeper waters, however, are generally purer than those near the surface, although their mineral content is likely to be higher.

\section{PROTECTION OF WELLS.}

NONFLOWING WELLS.

Many of the conditions favorable to pollution of the shallow wells likewise favor the contamination of deep wells, but as the causes and remedies have already been discussed, especially in connection with the section on "Safety distance" (pp. 42-44) they do not require further consideration at this point.

The water of deep wells when first encountered is usually safe and rightfully has a good reputation, so that people often go to great expense in drilling for deep rock waters. Unfortunately, however, many fail to realize that unless care is taken, it is possible for deep wells to become polluted by the entrance of surface waters. In

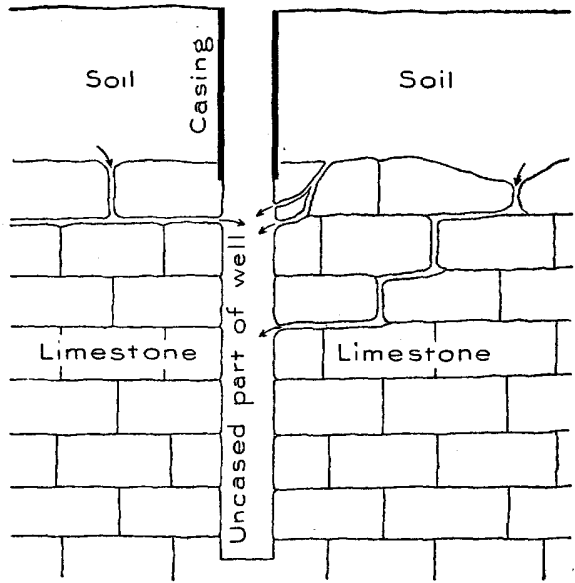

Figure 21.-Diagram showing danger of pollution where casing is carried only to rock. regions where the rock is within a few feet of the surface, for instance, the casing may be carried only to the rock, the fact that pollution can enter the well through the rock crevices being entirely overlooked. (See fig. 21.) The chief precaution necessary against this danger is to carry the casing to a sufficient depth to shut off all surface waters entering through fissures. It is hard to say how deep it must be carried to remove all danger of contamination, but the crevices are usually limited to the upper part of the rock (fig. 21), 
and every additional foot of casing gives additional safety. Ten feet of casing in the rock would materially reduce the danger, while 25 feet would in most wells probably insure safety. The best plan, however, is to carry the casing from the surface down to the water-bearing seam. The casing should always be set with a tight joint at the bottom to prevent the entrance into the well of surface waters that find their way downward along the outside of the pipe.

Again, it is not unusual to drill new wells in the bottom of old dug wells and to allow the polluted surface waters to mingle with the pure rock waters.

Many towns situated on rock surfaces and using unprotected wells of the type mentioned have been visited by epidemics of typhoid fever, cholera, and other diseases, leading to the loss of many lives.

Another source of pollution, less common and possibly less dangerous than the preceding, arises from the fact that many casings are left open at the top, even when care has been taken to carry them to proper depths. Plate XVI, $A$, shows a good example of this kind, there being a considerable open space between the outer casing and the inner pump tube through which small animals and various kinds of dirt find access to the water below. Plate XVI, $B$, shows a casing properly protected, all openings being hermetically sealed by cement.

A fourth and very common means of contamination of deep wells is by leaks in the casing due to imperfect joints or to corrosion. The process of corrosion may be very rapid, the pipe in some wells with acid chalybeate waters lasting only a few years. No one expects a pipe laid in the ground near the surface to last many years, yet many seem to think that a well casing will last indefinitely. Unfortunately, this is far from true.

The detection of leaks is somewhat difficult. In some wells, however, water may be heard trickling in or may be seen by a light ray projected down the well by a mirror when the pump is withdrawn. The admixture of water from outside sources may sometimes be detected by a difference of the hardness of the well water, by an earthy taste or taste of decayed vegetation, or by a cloudiness due to silt brought in by superficial waters.

The remedy is usually to pull the old casing and replace it by a new one, the length of time the pipe is allowed to remain before replacement being determined by an estimate of its life based on the action of the water on the pump tube or other pipes. An alternative treatment sometimes employed when the leak is near the surface is to set a packer designed for the purpose in the space between the bottom of the pump tube and the casing and fill the space above with cement. 
FLOWING WELLS.

In order that water may have sufficient head to flow out upon the surface it must be confined under some impervious or relatively impervious clay or other bed. This effectually shuts out pollution from the overlying material, and any contamination that reaches the well must be transmitted laterally for relatively long distances. As pollution rarely extends through the ground to any great lateral distance from its source, it follows that artesian waters are almost never polluted.

In artesian wells the water, being under greater head than that in the surrounding materials, will páss outward through any leak that may develop rather than admit the water of lower head to the well. Suction, such as is developed in the Richards apparatus in laboratories, which might be conceived as drawing in outside water through openings in the casings, can not take place with the relatively low velocities of the water in the ordinary artesian wells. Even in a well in which the water has a very high velocity, the suction is so slight in proportion to the immense volume discharged that it may usually be neglected

INCREASIKG THE YIELD.

METHODS OF INCREASING ORIGINAL YIELD.

Shooting.-The practice of "shooting"-exploding a charge of nitroglycerine or other explosive in a well-has long been successfully employed in the oil regions and has in late years been used to increase the flow of water wells, in which dynamite is more. commonly used. The action of the dynamite is to shatter the surrounding rock, with the result that connection is frequently established with other crevices, in some wells largely increasing the water supply. (See fig. 22.) The dynamite is most effective in hard, brittle rocks, such

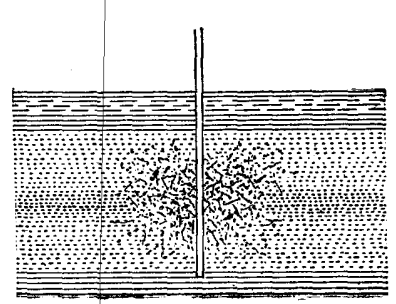

FIGURE 22,-Diagram showing loosening effect of shooting wells. as limestone, which are as a rule completely shattered by the explosion, and is least effective in soft tough shales, which are bent and compressed rather than broken.

Steam jet.-Shooting, owing to the character of the materials, is not usually practiced in unconsolidated deposits, in which the steam jet is sometimes used instead of dynamite. The steam is forced down a small pipe inside of a larger one and coming into contact with the water at the bottom turns it quickly into steam, the resulting explosion loosening the material or making a pocket about the bottom of the pipe. Where the materials are dense and clayey, the action of the steam jet may considerably increase the influx of water; in the more porous deposits it has less effect. 
Packing with gravel or sand.-It frequently happens that where the material is very fine it packs around the well so as to hinder the entrance of water. In such cases

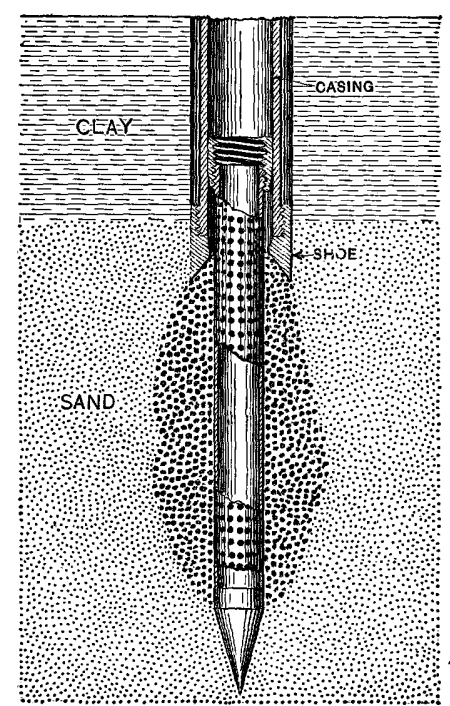

FIGURE 23.-Diagram showing formation of sand packing through pumping.

it is a common practice to drop a supply of pebbles into the well and with the aid of a drill force them out into the surrounding clay, etc., until a pocket of pebbles is produced through which the water flows freely to the well.

In quicksands, the space between the outer casing and the pump tube and strainer is often filled with sand through the heavy suction induced by pumping. This sand in many wells keeps back the quicksand while allowing the water to pass through it freely and to enter the well. (See fig. 23.)

Production of sand or other pockets by pumping.-Many of the materials yielding water to wells consist of mixtures of sand or gravel and clay. By heavily pumping a new well it is often possible to remove the fine clayey material, leaving the sand grains and pebbles in a sort of pocket about the well (fig. 24), the result being much like that produced by the artificial gravel pocket described in the preceding section. A similar method is employed in certain stiff clays, in which small open pockets at the bottom of the well are apparently produced by the heavy pumping.

\section{METHODS OF RESTORING LOST SUPPLIES.}

When a deep well is first sunk, it usually gives good supplies, but as time elapses the yield is found to decrease gradually until finally it is but a small fraction of its original amount. This decrease is commonly attributed to a decrease in the general supply of the region or to the drawing off of the water by newer and better wells. In many wells this is a real cause, but in others the failure is due rather to the deterioration of the old well than to the losses caused

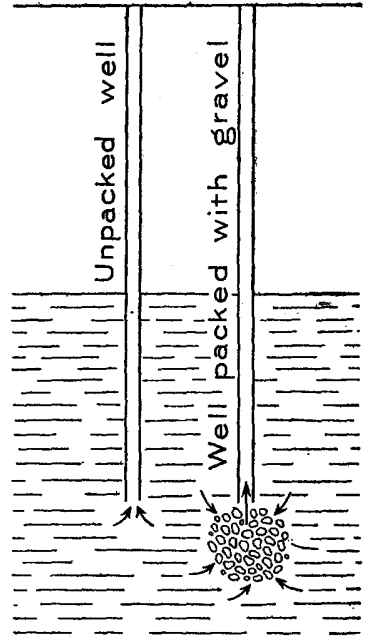

FIGURE 24.-Diagram showing advantages of packing with sand and gravel.

by new wells, which in reality have a large yield simply because they are new and in good condition. The chief causes of decrease or failure are clogging of the screen, entrance of sand, and leakage. 


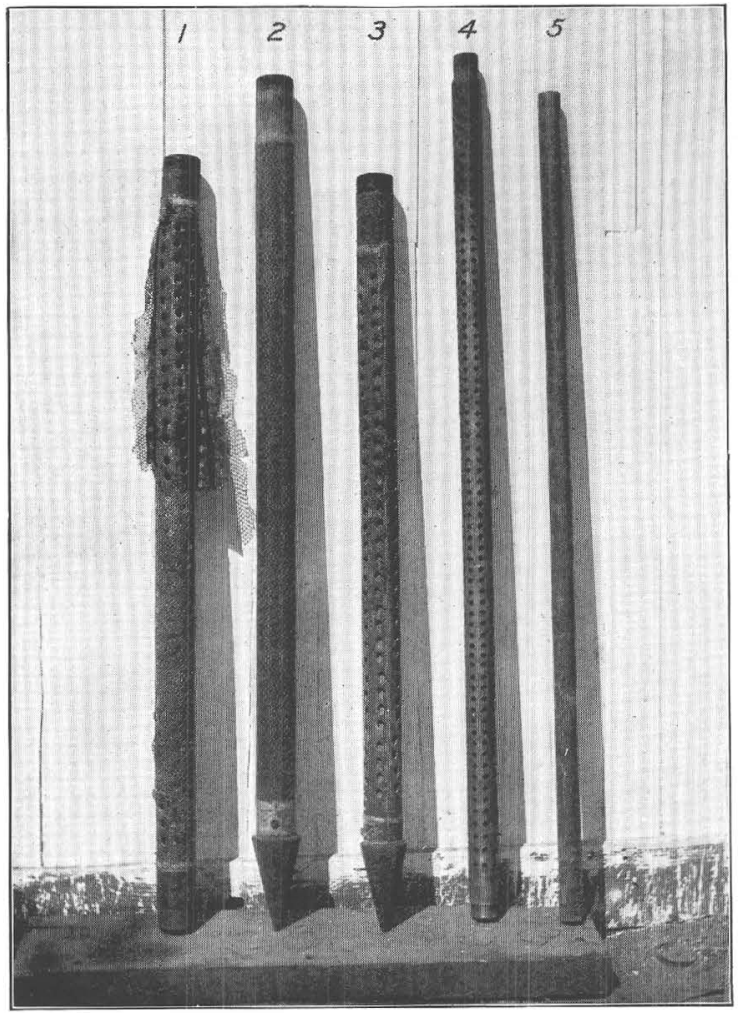

A. WELL POINTS.

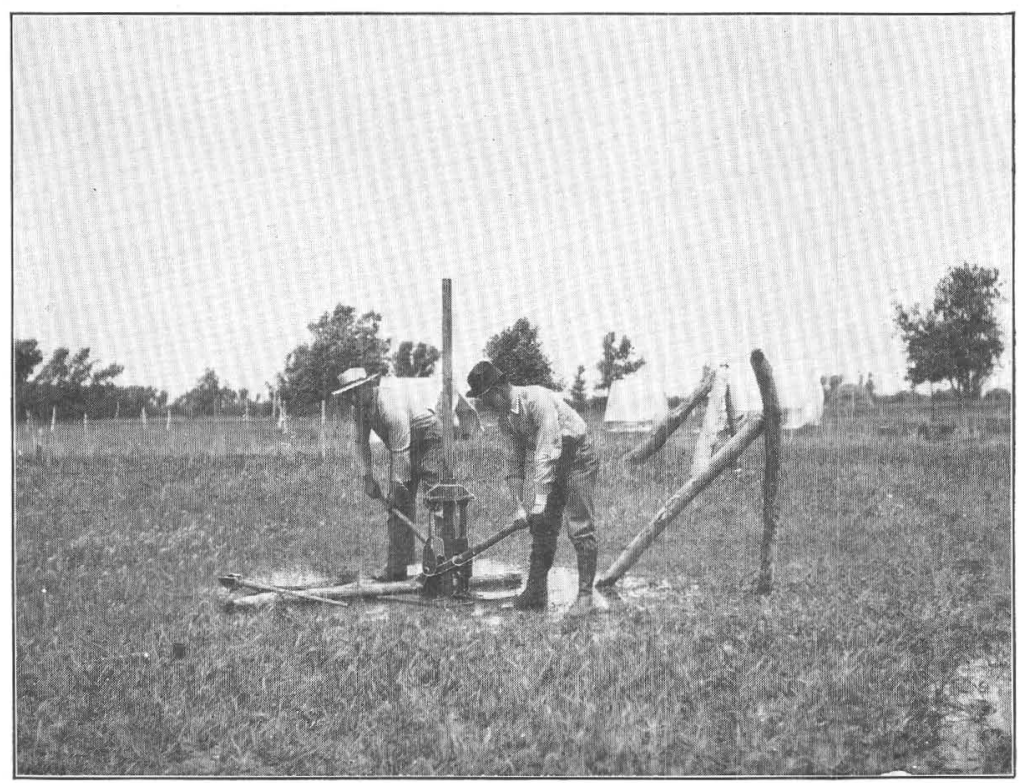

B. PULLING PIPE WITH JACK. 
Rescreening the well.-Of the causes of failure enumerated the clogging of the screen or strainer is probably the most common. This may result from the filling of the perforations by sand and silt sucked in with the water, but other very common causes are the closing of the pores by the deposition of iron or lime. Where the waters carry acids in solution, the screen is often attacked and corroded, the iron set free being redeposited in the sand about the screen, forming thick, impervious coatings of a sort of sandstone which sooner or later effectually shuts off the water.

When the matter collected about the well point is soft and loose, it can often be removed by back pressure produced by pumping heavily into the well, the outward current forcing back the accumulated silts. When

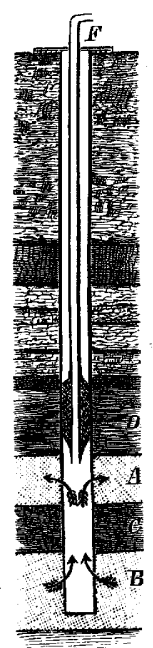

FTGURE 26.-

Section of well showing loss by le a k a ge from one deep bed into another. (After Cham berlin.)

this fails, the usual remedy is to pull the casing and screen, or the pump and well point, and replace it by a new one. (See Pl. XVII.)

Prevention of the entrance of sand.-If a well is not properly constructed or screened, sand or quicksand may enter the well in large quantities and greatly hinder the entrance of water. In some wells this is remedied by substituting a finer screen, and in others by packing gravel about the bottom of the well, or around the screen or strainer, as already described. The packing of sand about the strainer has enabled many wells to draw on quicksands that ordi-

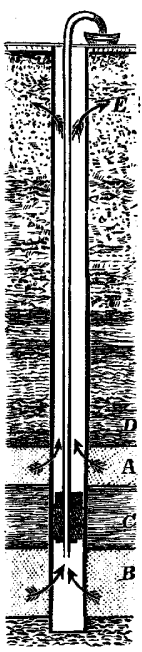

Frgure 25.Section of well showing loss by leakage into the superficial deposits. (After Cham berlin.) narily would have almost immediately choked and ruined the wells.

Prevention of leakage.-Leakage in wells affording acid waters is very prevalent, the pipes becoming rapidly corroded until holes appear in their walls through which the water from the well may escape. The only way to prevent leakage of this type is to recase the well.

In uncased wells there is much leakage into other nonsaturated beds, as is clearly shown by the accompanying diagrams (figs. 25 and 26). Figure 25 shows the water from two deep-lying beds being lost into one near the surface, and figure 26 shows a loss from one deep bed into another. The remedy for either condition is to carry the casing down to the principal water bed and not try to draw on two beds of different heads. 


\section{CISTERNS.}

The ordinary cistern is an excavation in the ground, usually circular in shape, lined with a supposedly impervious coating of cement or other material, and used for the storage of rain water. Cisterns are used chiefly where the supply of well water is insufficient or its quality objectionable.

\section{ADVANTAGES OF CISTERNS.}

Supplementary supplies.--In many of the best farming regions of the country, as in the Blue Grass region of Kentucky and elsewhere, the rocks either carry so little water or carry it so irregularly that many wells fail to obtain a sufficient supply to meet domestic needs and the demands of stock. In shaly regions the water supplies are even more uncertain and it is often impossible to procure the necessary supplies from wells. This is true also of many areas underlain by clay and of some areas characterized by thick beds of clayey till. In all these regions supplementary supplies of water are necessary, at least for stock, and where springs, ponds, or lakes are not available cisterns must be resorted to, and in some places they are necessary even for domestic supplies.

Softer and fresher water.-Rain water is the softest of all natural waters, hence is very desirable for washing and other domestic purposes, especially in limestone regions, where the water of many wells or springs is so hard that soap, instead of dissolving and making a good lather, forms a dirty-looking curdle or scum on the surface. In such regions much trouble is also caused by the formation of thick crusts of lime and magnesia on the inside of the kettles and other utensils and by the precipitation of the white, milky sediment which clouds the water when it has been boiled. In other regions, as in the Atlantic Coastal Plain, the water may be highly charged with soda, with the result that rice or other white foods cooked in it are turned a dirty yellow. Elsewhere, especially on low sandy beaches and the keys of our limestone coasts, the well water is brackish and unfit for drinking. All these difficulties are avoided if soft cistern water derived from the collection of the rain water is available.

Safety.-It is usually impossible for pollution to enter a properly constructed cistern - one in which the lining is water-tight-through the walls, and with a little care and by providing water-tight covers it is possible to keep out much of the undesirable matter from the top. Of course more or less dirt may be washed from the roof into the cistern, but the first run-off can be allowed to waste either by some automatic appliance or by hand, letting only the later and relatively pure water enter the cistern. A cistern, therefore, if properly made and cared for, is to be regarded as a practically safe source 
of supply. It is certainly far safer than the ordinary dug, bored, and punched well, and even than many of the shallower driven wells.

Convenience.-Another great advantage of a cistern is its convenience. As they are built near or even under a house, dairy, or barn, the water may often be pumped directly from them to the sink or to the dairy or watering trough.

Ease of cleaning.-Because of their shallowness and the smoothness of their walls cisterns can be much more quickly and thoroughly cleaned than wells. Consequently they are usually cleaned more frequently and the water is kept in better condition.

\section{DISADVANTAGES OF CISTERNS.}

Contamination by dirt from roof.- - The dirt from the roofs is very objectionable, including dust blown from barnyards and highways, the droppings of birds, etc. The remedy is, as already stated, to allow only that portion of the water falling during the latter part of a shower, after the dirt from the roof has been largely removed, to enter the cistern.

Liability to crack and admit pollution.-The greatest disadvantage of a cistern and one which subjects the users to grave danger is the liability to crack. No matter how good the cement used in the construction or how careful the workmanship, cracks are liable to develop and admit shallow and possibly polluted ground waters. It is to the waters entering in this way that the notable hardness often indicated in cistern waters is due. Cistern water under normal conditions is soft, and if it becomes hard it is a sure. indication that ground water has in some way found access to the cistern. It is a danger signal which should not be disregarded, and whenever it is noted the cistern should be emptied and repaired at once.

\section{CONDITIONS UNDER WHICH CISTERNS ARE DESIRABLE.}

Cisterns are desirable (1) wherever the rock, clay, or other materials in which the well is sunk are poor water bearers; (2) wherever the ground water is too hard for washing, too alkaline for cooking, or too brackish for drinking; and (3) wherever waters from other sources are inherently unsafe. They are especially desirable in the larger towns where the houses are crowded and the wells often polluted, and where no public supply is available. Again, on farms, where wells are not infrequently located near barns or other sources of pollution, cisterns often constitute the only safe source of water.

SIZE.

The ordinary cistern, usually 5 or 6 feet in width and 10 or 12 feet deep, almost invariably fails to meet the demands on it during extended periods of drought. To insure a supply which can always 
be depended on either for domestic or for stock use, much larger cisterns are necessary.

If rainfall were equally distributed throughout the year and if the consumption of water were regular, a cistern large enough to hold one or two months' supply would be sufficient, but, unfortunately, the rainfall is ordinarily very irregular, from one-half to two-thirds of the entire precipitation of the year not infrequently falling in three or four of the colder months, while the remainder is distributed over the eight or nine warmer months. This reason alone would make large cisterns desirable, but still another reason is fourd in the larger consumption of water in the warmer season, which is generally the period of deficient rainfall. To be sure of a supply through long periods of drought such as are likely to occur one or more times in each decade, it is necessary to have a cistern that will hold when full two-thirds or three-fourths of the total amount required during the year. For drinking, cooking, and washing each person on a farm ordinarily uses from 5 to 10 gallons or more of water a day, and each head of stock ordinarily requires from 6 to 15 gallons. The amount used, however, depends so largely on local conditions that it should be carefully ascertained in each specific case before the size of a cistern is determined. An allowance of $2 \dot{\xi}$ to 35 per cent should also be made for loss due to the deflection of the earlier and more or less dirty washings from the roof, the overflow of gutters in heavy storms, the loss by snow sliding or blowing from the roof, the leakage of pipes, and other minor causes. The total amount needed and the allowance for loss having been determined, it becomes possible to calculate the size of cistern required. The volume of a round cistern is approximately five-sixths of the product obtained by multiplying the square of the diameter by the depth.

For assistance in determining the amount of water annually falling on a roof the following table, showing the number of gallons falling on each square foot on roofs of gentle, medium, and steep slope at different rates of rainfall, is presented. The annual rainfall of any particular locality can be ascertained from the United States Weather Bureau.

Amount of water falling annually on roofs of varying slopes at different rates of rainfall.

\begin{tabular}{|c|c|c|c|c|c|c|c|c|c|c|c|}
\hline \multicolumn{2}{|c|}{ Slope of roof. } & \multicolumn{10}{|c|}{$\begin{array}{l}\text { Water falling on roof, in gallons per square foot, when annual rain- } \\
\text { fall, in inches, is- }\end{array}$} \\
\hline Degrees. & $\begin{array}{l}\text { Ratio } \\
\text { (vertical } \\
\text { to hori- } \\
\text { zontal). }\end{array}$ & 15 & 20 & 25 & 30 & 35 & 40 & 45 & 50 & 55 & 60 \\
\hline $\begin{array}{l}45 \\
26 \frac{1}{2} \\
63 \frac{1}{2}\end{array}$ & $\begin{array}{l}1: 1 \\
1: 2 \\
2: 1\end{array}$ & $\begin{array}{l}6.6 \\
8.3 \\
4.2\end{array}$ & $\begin{array}{r}8.8 \\
11.8 \\
5.6\end{array}$ & $\begin{array}{r}11.0 \\
14.8 \\
7.0\end{array}$ & $\begin{array}{r}13.2 \\
17.7 \\
8.3\end{array}$ & $\begin{array}{r}15.4 \\
20.7 \\
9.7\end{array}$ & $\begin{array}{l}17.6 \\
23.6 \\
11.1\end{array}$ & $\begin{array}{l}19.8 \\
26.6 \\
12.5\end{array}$ & \begin{tabular}{|l|}
22.0 \\
29.5 \\
13.9
\end{tabular} & $\begin{array}{l}24.2 \\
32.5 \\
15.3\end{array}$ & $\begin{array}{l}26.4 \\
35.4 \\
16.7\end{array}$ \\
\hline
\end{tabular}




\section{LOCATION.}

Theoretically the location of a cistern makes little difference in its liability to pollution, but practically it is of the greatest importance. As has been indicated, cracks in the walls are of common occurrence, in some cisterns being sufficiently open to admit enough outside water to make the supply noticeably hard, and where such water can enter pollution can enter also. Bacteria or disease germs can develop in substances which can not be filtered from the water and it is entirely possible for pollution by such means to enter the cistern through cement walls even when there are no cracks. It is therefore highly desirable that the cistern should not be located near a sewage drain, barnyard, or other source of contamination, the same precautions being observed as have been indicated for wells (pp. 44-45). The site selected should be in firm ground, as otherwise there will be danger of the cistern settling and cracking. Roots of trees are also a frequent cause of injury, and cisterns should be located as far away from them as possible.

\section{CONSTRUCTION.}

The excavation should be made large enough and deep enough to permit the laying of proper foundations and adequate walls. For curbing either stone or brick laid in mortar and cemented on the inside with a thick coating of hydraulic cement may be used. It is preferable that the top be arched over with brick or stone and lined with cement. An opening, provided with an air-tight cover, through which a person may enter the cistern for purposes of examination, cleaning, and repair, should be left at the top. After the completion of the cistern, it should be frequently examined, in order to detect and remedy any cracks or other defects due to settling, the action of frost, penetration of tree roots, etc.

\section{COMBINATION WELLS AND CISTERNS.}

Although cisterns of the dimensions indicated in the preceding section will supply enough water for domestic use in a small family, they will not supply enough for stock. In fact, unless the farm buildings are very large or numerous it is, as a rule, impracticable to procure enough cistern water to supply more than a few head of stock, and it is therefore generally necessary to utilize the ground-water supplies. These are sometimes too far from the surface to be available during the summer, but there is almost always enough water in the ground in winter, and the ideal provision would be to store a portion of the winter supply for summer use.

In the winter the ground-water level is high, often standing only a few feet below the surface, but in summer it is usually much lower, often many feet from the top of the ground. If a well is carried deep 
enough, sufficient water cản in most places be obtained, but many wells are too shallow to give never-failing supplies, and as a consequence they may be short of water in times of drought. If the water in the well in the winter could be retained till summer, there would be little difficulty with the supply of most wells, but, unfortunately, as the ground-water level falls the water in the wells falls also. In figure 27 $a c$ indicates the depth of water in a well during the winter, and $b c$ indicates its depth in the summer when the water level is at $b$. The volume at depth $a c$ might be sufficient for the whole year, and that at depth $b c$ insufficient to last through the summer. To preserve the

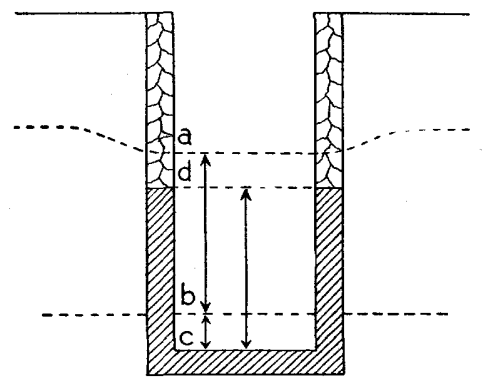

FIGURE 27.-Combination well and cistern. winter supply it is necessary to cement the bottom and walls of the well nearly to the winter water level, as shown by the heavy lines in the figure, thus converting it into a semicistern. When this is done the well will fill during the winter to the level $a$ and will still contain water to about the level $d$ after the ground water has fallen to $b$.

Combination wells and cisterns of this type are especially dangerous if near any source of pollution, hence they are recommended only for stock wells located at some distance from buildings and barnyards. They should be used for domestic supplies only where on higher ground and at some distance from any source of pollution. Cisterns completely cemented and covered are safest where buildings are near.

In some places it is the practice to turn the water from buildings into a well, but, although the well water is somewhat softened thereby, there is no gain in amount, as water will not stand in an ordinary well higher than in the outside ground, the equivalent of the extra water turned into the well being lost by outward percolation. 

